\title{
Bryozoan fauna from the Permian (Artinskian-Kungurian) Zhongba Formation of southwestern Tibet
}

\author{
Andrej Ernst
}

\begin{abstract}
The bryozoan assemblage from the Zhongba Formation of southwestern Tibet includes 30 species of 25 genera. Seven species are new: Fistulipora sakagamii n. sp., Dybowskiella hupehensiformis n. sp., Etherella tibetensis n. sp., Dyscritella lii n. sp., Streblotrypa (Streblotrypa) parviformis n. sp., Timanotrypa australis n. sp., and Protoretepora irregularis $\mathrm{n}$. sp. One genus with one species is also new: Tibetiporella ornata n. gen. n. sp. The described fauna implies a Cisuralian (Artinskian-Kungurian) age of the Zhongba Formation and shows relationships to the Cisuralian faunas of Thailand, Western Australia, Oman, Timor, central Pamir, Iran, Urals, and other Tibetan localities. The bryozoan fauna from the Zhongba Formation shows an intermixture of both Boreal and Gondwana elements, and implies stronger faunal migrations into the tropical region from both the north and south. Palaeoecological analysis suggests that the Zhongba Formation was deposited in a middle shelf setting some distance from shoreline, probably influenced by local currents.
\end{abstract}

Andrej Ernst. Institut für Geologie, Universität Hamburg, Bundesstr. 55, 20146 Hamburg, Germany. Andrej.Ernst@uni-hamburg.de

Keywords: Bryozoa; taxonomy; palaeobiogeography; new genus; new species

Submission: 8 July 2015. Acceptance: 10 April 2016.

\section{INTRODUCTION}

The Indus-Tsangbo (Yarlung-Zangbo) Suture Zone in southern Tibet marks the collision between the Indian and Eurasian plates (Hodges, 2000). In the middle part (southwestern Tibet) of the suture, a small stratigraphical terrane called the Zhongba microterrane (Li et al., 2014a) narrowly pinches out between the two mélange branches of the suture.

The eastern part of the Zhongba microterrane has been assigned to the middle-late Permian in
Chinese regional geological (unpublished) reports, but it was recently dated as Ordovician through Triassic and disaggregated as three lithostratigraphic units: the Ordovician-Silurian Ziqupu Group, Devonian Nadeng'er Formation and CarboniferousPermian Quga Group (Li et al., 2014b). The Quga Group was subdivided into three parts: Carboniferous-Lower Permian Gangzhutang Formation, Lower-Middle Permian Zhongba Formation, and Middle-Upper Permian Kazhale Formation ( $\mathrm{Li}$ et al., 2014b).

http://zoobank.org/6F0DE44D-32BD-4882-9C38-FF76446D15EA

Ernst, Andrej. 2016. Bryozoan fauna from the Permian (Artinskian-Kungurian) Zhongba Formation of southwestern Tibet.

Palaeontologia Electronica 19.2.15A: 1-59

palaeo-electronica.org/content/2016/1462-bryozoan-fauna-of-tibet

Copyright: Palaeontological Association May 2016 
The Zhongba Formation is composed of pinkish red dolomites and variegated dolomitic bioclastic limestones, ranging from $20-100 \mathrm{~m}$ thick. This formation contains abundant benthic fossils: crinoids, bryozoans, brachiopods, gastropods, and solitary corals. Fusulinds are few, whereas small agglutinating foraminifers are ubiquitous.

Bryozoa is very important animal group, which was widely distributed in marine habitats in the past. During the Palaeozoic, bryozoans played significant role in reefs and other shallow marine biotopes (Cuffey, 1977). Due to their mostly calcitic and diagenetically stable skeletons, bryozoans can be used for various purposes in palaeontology and stratigraphy (Bancroft, 1987; Taylor and Allison, 1998; Smith et al., 2006).

Permian Bryozoa display a high diversity and wide distribution worldwide. Well-studied faunas are known from North America, Eurasia, and Australia, which were successfully used for palaeobiogeographical reconstructions (Ross and Ross, 1990; Ross 1995; Gilmour and Morozova, 1999). Ross (1995) assigned Tibet to the Central Tethys province which also includes Transcaucasia, part of Afghanistan, Mongolia, and northeastern, central eastern, and southwestern China. Tibetan faunas belong to the Tethys occurring in tropical conditions.

One of the earliest publications regarding Permian bryozoans from Tibet was that of Metz (1946) who described several bryozoan species from northern Tibet. A series of more recent publications by Chinese authors describe extensive bryozoan faunas from the Permian of Tibet (e.g., Yang et al., 1981; Yang and Lu, 1983; Liu and Wang, 1987; Xia, 1991). Sakagami et al. (2006) mentioned some bryozoans from the Lower Permian (Sakmarian) of the southern Tibet.

The present paper is devoted to the taxonomic description of a bryozoan fauna from the Zhongba Formation (Lower-Middle Permian) of the Zhongba area in southwestern Tibet. This fauna includes 30 species of 25 genera. Palaeobiogeographical, stratigraphical, and ecological implications of this fauna are discussed here.

\section{MATERIAL AND METHODS}

Material for this study was collected by Xianghui Li (Nanjing University, China) and his colleagues from the Zongba Formation in Zhongba area (Figure 1) of southwestern Tibet in the summers of 2010-2012 during 1:50,000 geological mapping and provided to the author for a taxonomic investigation on bryozoans (Li et al., 2014a, b). The material comes from the lower part of the Zhongba Formation (Xianghui $\mathrm{Li}$, personal commun., 2011) and is deposited at the Senckenberg Museum (Frankfurt am Main, Germany). The following samples are from the Zhongba Formation (GPS coordinates in brackets): D4437F8 (E 84.31536, N 29.74233), D4437F9 (E 84.31536, N 29.74233), D4437F10 (E 84.31536, N 29.74233), D4437F11 (E 84.31536, N 29.74233), D4437F12 $(E$ 84.31536, $N$ 29.74233), D4437F13 (E 84.31536, N 29.74233), D4437F14 (E 84.31536, N 29.74233), D4437F15 (E 84.31536, N 29.74233), D4437F17 (E 84.31536, N 29.74233), D4439F2 (E 84.31111, N 29.73889), P5170F1 (E 83.76894, N 29.93333), S09-01F4 (E 83.79028, N 29.89667), S09-01F4 (E 83.79028, N 29.89667), S09-01F6 (E 83.79028, N 29.89667).

The studied samples comprise grey to blackish, fossil-rich limestones (Figure 2.1), which are mainly represented by rudstones, grainstones, packstones, and bindstones (Figure 2.2-4). Besides bryozoans, the limestones contain crinoids, brachiopods, and gastropods. From this material, 150 randomly oriented thin sections of various sizes ( $28 \times 48 \mathrm{~mm}$ [ $=92], 50 \times 50 \mathrm{~mm}$ [n $=49]$, and $50 \times 70 \mathrm{~mm}[\mathrm{n}=9]$ ) were prepared. Thin sections are deposited at the Senckenberg Museum (Frankfurt am Main, Germany). Material included in the present publication is numbered SMF 23.007-SMF 23.098 and SMF 23.131-SMF 23.268. These numbers refer to the separate bryozoan fragments in thin sections, the system used at the Senckenberg Museum. Bryozoans were investigated in thin sections using a binocular microscope in transmitted light. The spacing of morphological structures was measured as a distance between their centres. Statistics were summarized using arithmetic mean, sample standard deviation, coefficient of variation, and minimum and maximum values.

The author does not follow the complete taxonomic procedure suggested by Snyder (1991) for fenestrates. It is often impossible to measure all the 43 morphological characters involved in this taxonomic system. The available material does not allow the preparation of ideally oriented thin sections or acetate peels, and the number of measurements per colony would not provide the necessary statistic background for such an approach. Moreover, some of the measured characters like the thickness of the reverse-wall laminated layer can vary strongly depending on the age of the colony part. The minimum chamber width varies strongly in various deep sections. Therefore, a reduced set 


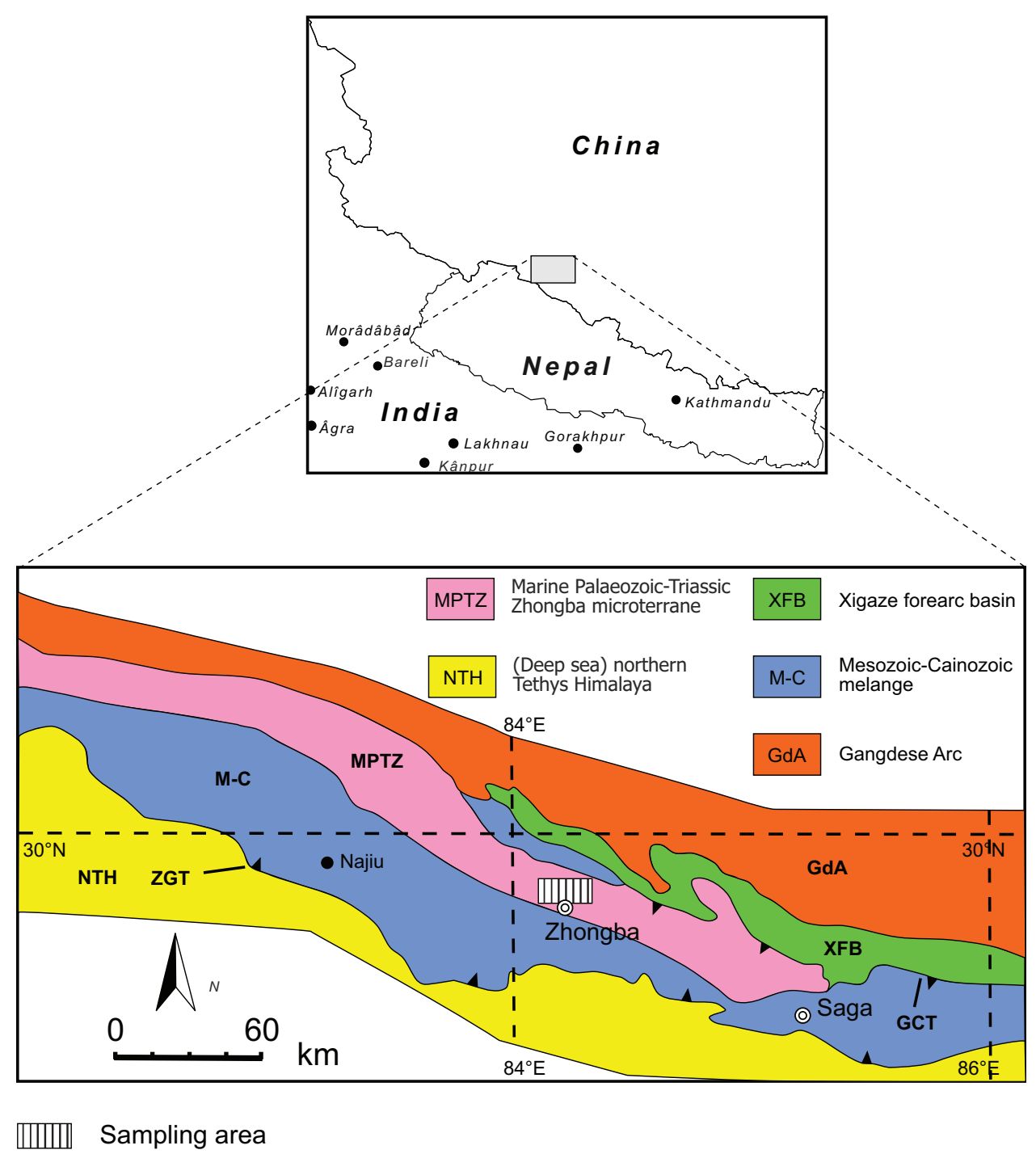

FIGURE 1. Position of the sampling area and tectonic setting of the Tibetan Plateau and Southern China (simplified after Dai et al., 2011). GCT: Great Counter thrust; ZGT: Zhongba-Gyangze thrust.

of characters suggested by Snyder (1991) has been used in this publication for the discrimination of fenestrate species.

\section{SYSTEMATIC PALAEONTOLOGY}

Phylum BRYOZOA Ehrenberg, 1831

Class STENOLAEMATA Borg, 1926

Superorder PALAEOSTOMATA Ma, Buttler, and Taylor, 2014

Order CYSTOPORATA Astrova, 1964

Suborder FISTULIPORINA Astrova, 1964

Family FISTULIPORIDAE Ulrich, 1882

Genus FISTULIPORA M'Coy, 1849

Type species. Fistulipora minor M'Coy, 1849. Carboniferous; England.
Diagnosis. Massive, encrusting, or ramose colonies. Cylindrical autozooecia with thin walls and complete diaphragms. Apertures rounded, possessing horseshoe-shaped lunaria. Autozooecia separated by the extrazooecial vesicular skeleton. Remarks. Fistulipora M'Coy, 1849 differs from Eridopora Ulrich, 1882 in having rounded, horseshoeshaped lunaria instead of triangular ones. Furthermore, Eridopora develops persistently encrusting colonies, whereas Fistulipora may also develop massive and branched colonies.

Occurrence. Ordovician to Permian; worldwide.

Fistulipora enodata Gorjunova, 1970

Figure 3.1-4; Table 1

1970 Fistulipora enodata Gorjunova, p. 61, pl. 21, fig. 4. 

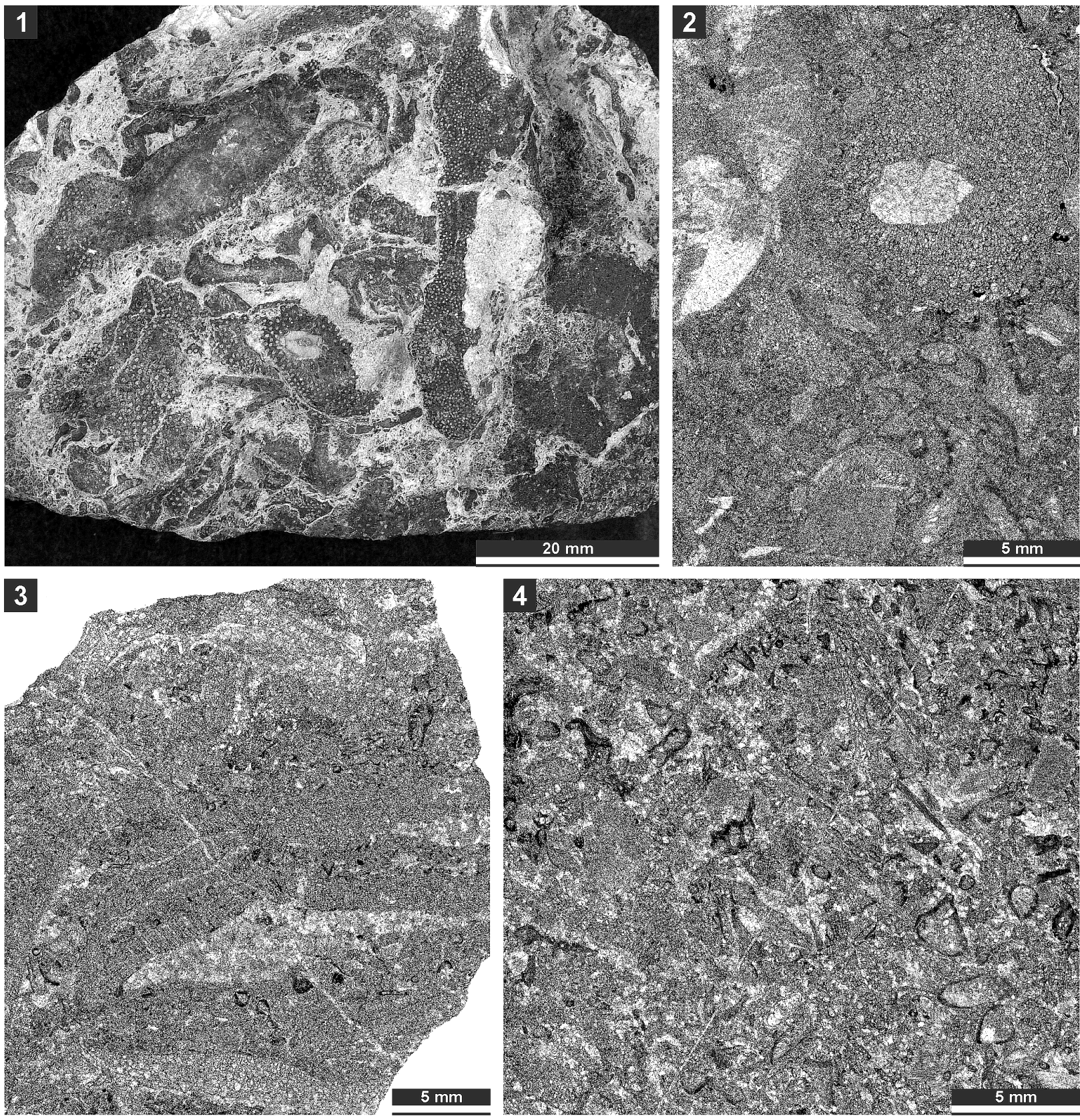

FIGURE 2. Lithological characteristics of the limestones from the Zhongba Formation. 1, limestone sample with abundant bryozoans (SMF 23.262); 2, rudstone containing crinoids, cystoporate (Fistulipora enodata Gorjunova, 1970) and fenestrate bryozoans (SMF 23.263); 3, bindstones with Fistulipora guttata Trizna and Klautzan, 1961 (SMF 23.264); and 4, grain- to packstones with bryozoan and crinoid fragments (SMF 23.265).

1975 Fistulipora enodata Gorjunova, 1970; Gorjunova, p. 42, pl. 1, fig. 1.

1987 Fistulipora enodata Gorjunova, 1970; Liu and Wang, p. 4, pl. 1, figs. 4a-b, pl. 2, figs. 1-a-b.

1991 Fistulipora enodata Gorjunova, 1970; Xia, p. 957, pl. 5, figs. 13-14.

Material. SMF 23.007-SMF 23.021.
Description. Encrusting, partly multilayered colony, separate sheets $1.8-2.8 \mathrm{~mm}$ thick. Autozooecia growing from thin epitheca, bending at their bases to the colony surface. Autozooecial diaphragms rare to absent, thin. Autozooecial apertures circular to oval. Lunaria well-developed, rounded, disappearing in deeper sections; ends of lunaria not indenting into autozooecia. Vesicles small to medium, high, separating autozooecia in 

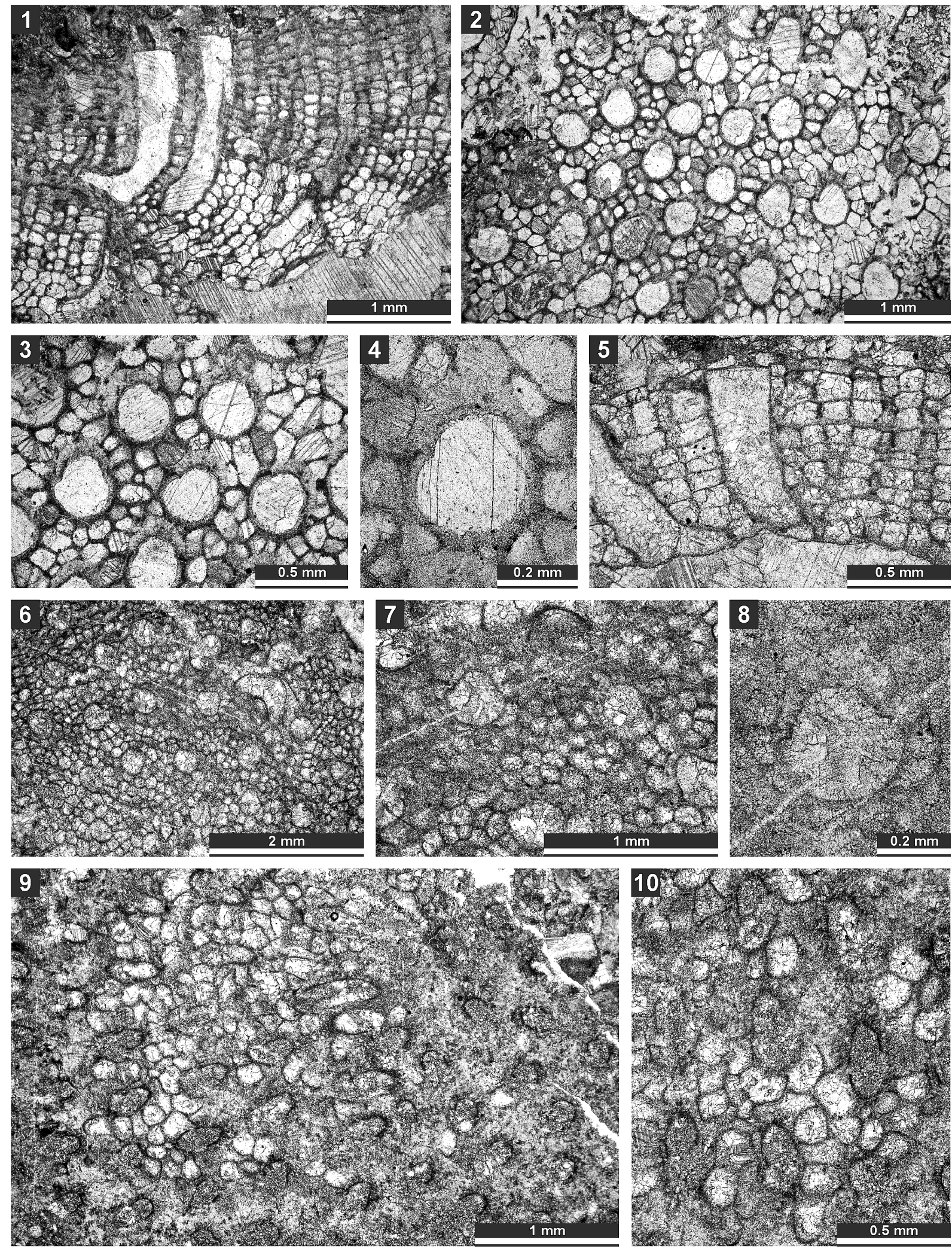

FIGURE 3. Thin section photographs of Fistulipora enodata Gorjunova, 1970, SMF 23.014 (1-4); Fistulipora guttata Trizna and Klautzan, 1961, SMF 23.025 (5-8); and Fistulipora sakagamii n. sp., holotype SMF 23.028 (9 and 10). 1 and 5, longitudinal section showing autozooecial chambers and vesicular skeleton; and 2-4, 6-8, 9, and 10, tangential sections showing autozooecial apertures and vesicles. 
TABLE 1. Measurements of Fistulipora enodata Gorjunova, 1970. Abbreviations: $N=$ number of measurements; $X=$ mean; $\mathrm{SD}=$ standard deviation; $\mathrm{CV}=$ coefficient of variation; $\mathrm{MIN}=$ minimal value; $\mathrm{MAX}=$ maximal value.

\begin{tabular}{lcccccc}
\hline & N & X & SD & CV & MIN & MAX \\
\hline Autozooecial aperture width, mm & 35 & 0.30 & 0.032 & 10.87 & 0.24 & 0.38 \\
Autozooecial aperture spacing, $\mathrm{mm}$ & 35 & 0.58 & 0.067 & 11.47 & 0.45 & 0.75 \\
Vesicle diameter, mm & 35 & 0.13 & 0.034 & 27.24 & 0.07 & 0.21 \\
Vesicle spacing, mm & 35 & 0.11 & 0.025 & 21.80 & 0.08 & 0.17 \\
Vesicles per aperture & 20 & 12.6 & 1.188 & 9.43 & 11.0 & 15.0 \\
Lunarium length, mm & 20 & 0.14 & 0.024 & 17.26 & 0.10 & 0.18 \\
Lunarium width, mm & 20 & 0.25 & 0.028 & 11.30 & 0.20 & 0.29 \\
\hline
\end{tabular}

TABLE 2. Measurements of Fistulipora guttata Trizna and Klautzan, 1961. Abbreviations as for Table 1.

\begin{tabular}{lcccccc}
\hline & $\mathbf{N}$ & $\mathbf{X}$ & $\mathbf{S D}$ & $\mathbf{C V}$ & MIN & MAX \\
\hline Autozooecial aperture width, $\mathrm{mm}$ & 30 & 0.28 & 0.038 & 13.89 & 0.23 & 0.38 \\
Autozooecial aperture spacing, mm & 30 & 0.66 & 0.073 & 11.04 & 0.55 & 0.80 \\
Vesicle diameter, mm & 30 & 0.11 & 0.030 & 28.08 & 0.05 & 0.19 \\
Vesicle spacing, mm & 25 & 0.10 & 0.022 & 21.78 & 0.05 & 0.13 \\
Vesicles per aperture & 30 & 12.0 & 1.564 & 13.07 & 9.0 & 16.0 \\
Lunarium length, mm & 15 & 0.14 & 0.037 & 26.91 & 0.08 & 0.23 \\
Lunarium width, mm & 15 & 0.21 & 0.030 & 14.18 & 0.17 & 0.29 \\
Lunarium thickness, mm & 15 & 0.08 & 0.031 & 40.31 & 0.03 & 0.13 \\
\hline
\end{tabular}

1-2 rows, 11-15 surrounding each autozooecia aperture, with rounded to flat roofs, polygonal in tangential section. Autozooecial walls granular prismatic, $0.005-0.015 \mathrm{~mm}$ thick. Maculae not observed.

Remarks. Fistulipora enodata Gorjunova, 1970 differs from F. timorensis Bassler, 1929 in larger autozooecial apertures (aperture width $0.24-0.38 \mathrm{~mm}$ vs. $0.22-0.28 \mathrm{~mm}$ in F. timorensis).

Occurrence. Lower Permian, Artinskian; Tajikistan (Pamir). Lower Permian; Rutog, southwestern Tibet. Xiala Formation, ?Middle Permian; Xainza, southwestern Tibet. Zhongba Formation, Permian (late Cisuralian-Guadalupian); Zhongba area of southwestern Tibet.

Fistulipora guttata Trizna and Klautzan, 1961 Figure 3.5-8; Table 2

1961 Fistulipora guttata Trizna and Klautzan, p. 379-380, pl. 1, figs. 1-3.

Material. SMF 23.022-SMF 23.027.

Description. Encrusting, partly multilayered colony, separate sheets $1.0-1.5 \mathrm{~mm}$ thick. Autozooecia growing from thin epitheca, bending at their bases to the colony surface. Autozooecial diaphragms rare to absent, thin. Autozooecial apertures circular to oval. Lunaria well-developed, rounded, disappearing in deeper sections; ends of lunaria not indenting into autozooecia. Vesicles small to medium, high, separating autozooecia in 2-4 rows, 9-16 surrounding each autozooecia aperture, with rounded to flat roofs, polygonal in tangential section. Autozooecial walls granular prismatic, $0.005-0.015 \mathrm{~mm}$ thick. Small maculae consisting of vesicular skeleton present, 1.0-1.3 $\mathrm{mm}$ in diameter.

Remarks. Fistulipora guttata Trizna and Klautzan, 1961 differs from F. milleporacea Bassler, 1929 from the Lower Permian of Timor in smaller autozooecial apertures (average aperture width 0.28 $\mathrm{mm}$ vs. $0.35 \mathrm{~mm}$ in F. milleporacea). Fistulipora guttata differs from F. enodata Gorjunova, 1970 in smaller apertures and larger distances between aperture centres (average aperture width $0.28 \mathrm{~mm}$ vs. $0.30 \mathrm{~mm}$ in $F$. enodata; average aperture spacing $0.66 \mathrm{~mm}$ vs. $0.58 \mathrm{~mm}$ in $F$. enodata), and in vesicles separating autozooecia.

Occurrence. Lower Permian (Artinskian) of Urals. Zhongba Formation, Permian (upper CisuralianGuadalupian); Zhongba area of southwestern Tibet.

Fistulipora sakagamii n. sp.

Figures 3.9-10, 4.1-2; Table 3

zoobank.org/08AABC94-467F-4885-86D3-8549C9134902

1975 Fistulipora sp. indet. Sakagami, p. 35, pl. 4, figs. 5-6. 
TABLE 3. Measurements of Fistulipora sakagamii n. sp. Abbreviations as for Table 1.

\begin{tabular}{lcccccc}
\hline & N & X & SD & CV & MIN & MAX \\
\hline Autozooecial aperture width, mm & 13 & 0.15 & 0.014 & 9.39 & 0.14 & 0.19 \\
Autozooecial aperture spacing, mm & 7 & 0.42 & 0.034 & 8.20 & 0.36 & 0.46 \\
Vesicle diameter, mm & 10 & 0.12 & 0.021 & 17.78 & 0.09 & 0.16 \\
Vesicles per aperture & 4 & 8.5 & 1.000 & 11.76 & 8.0 & 10.0 \\
Lunarium length, mm & 7 & 0.13 & 0.030 & 23.01 & 0.09 & 0.16 \\
Lunarium width, mm & 7 & 0.14 & 0.023 & 16.55 & 0.10 & 0.18 \\
Lunarium thickness, mm & 7 & 0.07 & 0.015 & 21.35 & 0.05 & 0.09
\end{tabular}

Etymology. The species is named in honour of Sumio Sakagami, who has contributed greatly to the research on Palaeozoic bryozoans.

Holotype. SMF 23.028.

Paratype. SMF 23.029.

Type locality. Zhongba area of southwestern Tibet (E 84.31536, N 29.74233).

Type stratum. Zhongba Formation, Permian (upper Cisuralian-Guadalupian).

Diagnosis. Thin encrusting colony; lunaria welldeveloped, horseshoe-shaped; apertures separated by 1-3 rows of vesicles; 8-10 vesicles surrounding each aperture.

Description. Thin encrusting colony. Autozooecia growing from thin epitheca, bending at their bases to the colony surface. Autozooecial diaphragms rare to absent, thin. Autozooecial apertures circular to oval. Lunaria well-developed, long, horseshoeshaped; ends of lunaria slightly indenting into autozooecia. Vesicles small to medium, high, separating autozooecia in 1-3 rows, 8-10 surrounding each autozooecia aperture, with rounded to flat roofs, polygonal in tangential section. Autozooecial walls granular prismatic, $0.005-0.015 \mathrm{~mm}$ thick. Maculae not observed.

Remarks. Fistulipora sakagamii n. sp. differs from F. rutogensis Xia, 1991 from the Chainaha Formation (Middle Permian) of southwestern Tibet, in smaller autozooecial apertures $(0.14-0.19 \mathrm{~mm}$ vs. $0.24-0.30 \mathrm{~mm}$ in F. rutogensis).

Occurrence. Lower Permian (Artinskian); Khao Hin Kling, Thailand. Zhongba Formation, Permian (upper Cisuralian-Guadalupian); Zhongba area of southwestern Tibet.

\section{Genus DYBOWSKIELLA Waagen and Wentzel, 1886}

Type species. Dybowskiella grandis Waagen and Wentzel, 1886. Permian; India.

Diagnosis. Ramose, hollow ramose, massive, or encrusting colonies. Autozooecia cylindrical, subcircular in transverse section of endozone, having rounded apertures, isolated by abundant polygonal vesicles. Basal diaphragms thin, straight or curved. Lunaria horseshoe-shaped, present in endozone and exozone; ends of lunaria inflect into autozooecial chamber. Autozooecial walls with granular boundary and light-coloured granular-prismatic cortex. Vesicular skeleton in endozone and exozone. Vesicles subrectangular with flat to slightly curved roofs. Small acanthostyles or tubuli in exterior stereom present. Monticules elevated or flash, with central cluster of vesicles surrounded by larger autozooecia in radial arrangement.

Remarks. Dybowskiella Waagen and Wentzel, 1886 differs from Fistulipora M'Coy, 1849 in the shape of lunaria, the ends of which inflect autozooecial chambers in Dybowskiella. Dybowskiella differs from Eridopora Ulrich, 1882 in having horseshoe-shaped lunaria instead of triangular ones. The shape of lunaria with inflecting ends is the only significant character for discrimination of Dybowskiella. However, the inflection grade of ends of lunaria varies strongly in the species of Fistulipora, Dybowskiella and Fistuliramus. Therefore, the discrimination of the genus Dybowskiella is relatively uncertain.

Occurrence. Middle Devonian-Upper Permian; worldwide.

Dybowskiella hupehensiformis $\mathrm{n}$. sp.

Figure 4.3-7; Table 4

zoobank.org/4DE81E30-ACFA-4160-91CF-A7E59260D862

1983 Dybowskiella hupehensis Yang, 1956; Yang and Lu, p. 266, pl. 9, figs. 1-4.

Etymology. The species is named after the species Dybowskiella hupehensis Yang, 1956 because of its close similarity.

Holotype. SMF 23.030.

Paratypes. SMF 23.031-SMF 23.035.

Type locality. Zhongba area of southwestern Tibet (E 84.31536, N 29.74233).

Type stratum. Zhongba Formation, Permian (upper Cisuralian-Guadalupian).

Diagnosis. Encrusting colony; diaphragms few to absent; lunaria well-developed, horseshoe- 

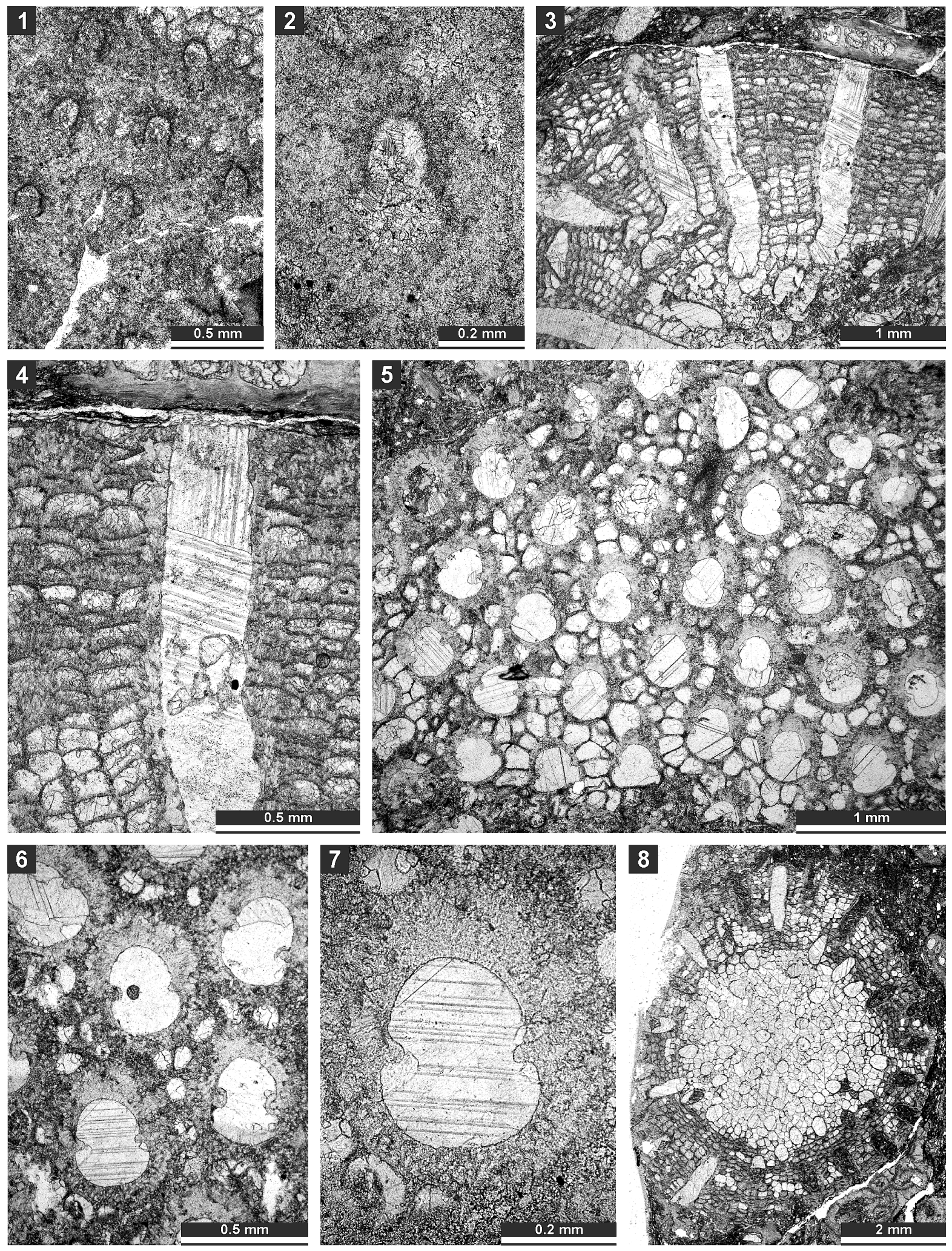

FIGURE 4. Thin section photographs of Fistulipora sakagamii n. sp., holotype SMF 23.028 (1 and 2); Dybowskiella hupehensiformis n. sp., holotype SMF 23.030 and paratype SMF 23.032 (3-7); and Fistuliramus xianzaensis Liu and Wang, 1987, SMF 23.037 (8). 1, 2, 5-7, tangential section showing autozooecial apertures and vesicles; 3 and 4, longitudinal section showing autozooecial chambers and vesicular skeleton; and 8, branch transverse section. 
TABLE 4. Measurements of Dybowskiella hupehensiformis n. sp. Abbreviations as for Table 1.

\begin{tabular}{lcccccc}
\hline & $\mathbf{N}$ & $\mathbf{X}$ & SD & CV & MIN & MAX \\
\hline Autozooecial aperture width, mm & 30 & 0.30 & 0.019 & 6.43 & 0.26 & 0.33 \\
Autozooecial aperture spacing, mm & 30 & 0.57 & 0.056 & 9.75 & 0.45 & 0.67 \\
Vesicle diameter, mm & 30 & 0.11 & 0.026 & 22.76 & 0.06 & 0.18 \\
Vesicle spacing, mm & 30 & 0.09 & 0.013 & 15.18 & 0.06 & 0.11 \\
Vesicles per aperture & 10 & 13 & 1.563 & 12.03 & 11.0 & 15.0 \\
Lunarium length, mm & 30 & 0.19 & 0.021 & 11.06 & 0.15 & 0.24 \\
Lunarium width, mm & 30 & 0.21 & 0.021 & 10.28 & 0.17 & 0.28 \\
Lunarium thickness, mm & 30 & 0.12 & 0.024 & 20.27 & 0.07 & 0.18 \\
\hline
\end{tabular}

shaped; apertures separated by 1-2 rows of vesicles; 11-15 vesicles surrounding each aperture; maculae consisting of vesicular skeleton.

Description. Encrusting, partly multilayered colony, separate sheets $1.15-1.75 \mathrm{~mm}$ thick. Autozooecia growing from thin epitheca, bending in the early exozone to the colony surface. Autozooecial diaphragms few to absent. Autozooecial apertures circular to oval. Lunaria well-developed, horseshoe-shaped, directed towards the next macula, disappearing in deeper sections; ends of lunaria indenting into autozooecia. Vesicles small to medium in size, high, separating autozooecia in 12 rows, 11-15 surrounding each autozooecia aperture, with rounded to flat roofs, polygonal in tangential section. Autozooecial walls granular prismatic, $0.005-0.015 \mathrm{~mm}$ thick. Maculae consisting of vesicular skeleton, $0.9-1.3 \mathrm{~mm}$ in diameter.

Remarks. Dybowskiella hupehensiformis n. sp. resembles the species described as Dybowskiella hupehensis Yang, 1956 by Yang and Lu (1983) from the Lower Permian Baliqliq Group of Kalpin in Western Xinjang, China. However, D. hupehensis Yang, 1956, originally described from the Chinsia Formation (Lower Permian, Artinskian-Kungurian) of Hupei, China, has significantly larger autozooecial apertures than the species described by Yang and Lu (1983) (aperture width 0.34-0.42 mm vs. $0.26-0.36 \mathrm{~mm}$ in the material of Yang and Lu). Dybowskiella hupehensiformis differs insignificantly from the material of $D$. hupehensis Yang, 1956 described by Yang and Lu (1983): aperture width $0.26-0.33 \mathrm{~mm}$ vs. $0.26-0.36 \mathrm{~mm}$, and aperture spacing $0.45-0.67 \mathrm{~mm}$ vs. $0.35-0.50 \mathrm{~mm}$.

Dybowskiella hupehensiformis $\mathrm{n}$. $\mathrm{sp}$. is similar to the species Dybowskiella sp. described by Yang and Lu (1983) from the Baliqliq Group of Kalpin in Western Xinjang, China (aperture width 0.26-0.33 $\mathrm{mm}$ vs. $0.30-0.33 \mathrm{~mm}$ in Dybowskiella sp.; aperture spacing $0.45-0.67 \mathrm{~mm}$ vs. $0.38-0.64 \mathrm{~mm}$ in
Dybowskiella sp.). Furthermore, D. hupehensiformis differs from $D$. crescens (Crockford, 1944) from the Lower Permian (Artinskian) of Western Australia in smaller autozooecial apertures (aperture width $0.26-0.33 \mathrm{~mm}$ vs. $0.29-0.43 \mathrm{~mm}$ in $D$. crescens).

Occurrence. Baliqliq Group, Lower Permian; Kalpin, Western Xinjiang, China. Zhongba Formation, Permian (upper Cisuralian-Guadalupian); Zhongba area of southwestern Tibet.

\section{Genus FISTULIRAMUS Astrova, 1960}

Type species. Fistuliramus sinensis Astrova, 1960. Upper Silurian (Ludlowian); Arctic Urals, Russia.

Diagnosis. Branched colonies; secondary overgrowths common. Autozooecia long, subcircular in transverse section of endozone; isolated by vesicular skeleton in exozones. Autozooecial apertures rounded to oval, usually arranged in regularly alternating longitudinal rows; maculae absent or poorly developed. Autozooecial diaphragms present in both in endozones and exozones, usually abundant. Lunaria in outer endozones and exozones, consisting of granular material, well-developed. Vesicles in long blisters in endozones, becoming more subquadrate in the transition region, decreasing in height in outer exozones. Autozooecial walls thin, granular in endozones; with thick laminated lining in exozones.

Remarks. Fistuliramus Astrova, 1960 differs from the similar genus Fistulipora M'Coy, 1849 in having constantly ramose colony form and monticules with a ring of larger autozooecia. Eofistulipora Morozova, 1959 differs from Fistuliramus in absence of vesicular skeleton in endozone and less abundant diaphragms in exozones.

Occurrence. Silurian-Permian; worldwide.

Fistuliramus xianzaensis Liu and Wang, 1987

Figures 4.8, 5.1-3; Table 5 

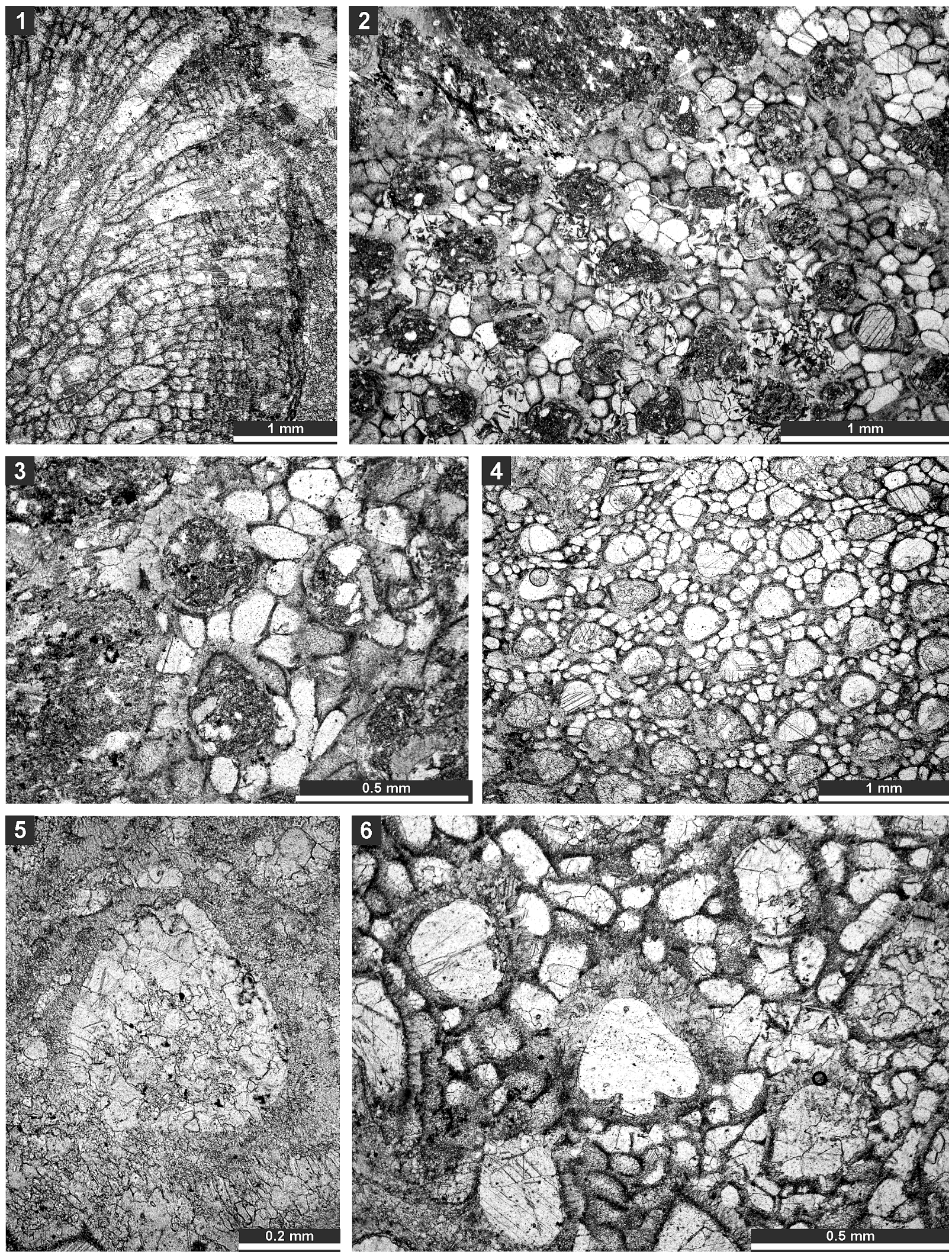

FIGURE 5. Thin section photographs of Fistuliramus xianzaensis Liu and Wang, 1987, SMF 23.042 (1) and SMF 23.038 (2 and 3); and Eridopora uncata Yang and Lu, 1983, SMF 23.052 (4 and 6) and SMF 23.051 (5). 1, longitudinal section; and 2-6, tangential section showing autozooecial apertures and vesicles. 
TABLE 5. Measurements of Fistuliramus xianzaensis Liu and Wang, 1987. Abbreviations as for Table 1.

\begin{tabular}{lcccccc}
\hline & $\mathbf{N}$ & $\mathbf{X}$ & $\mathbf{S D}$ & $\mathbf{C V}$ & MIN & MAX \\
\hline Branch diameter, mm & 6 & 7.4 & 0.928 & 12.49 & 5.9 & 8.3 \\
Exozone width, mm & 6 & 1.7 & 0.417 & 24.76 & 1.1 & 2.3 \\
Endozone width, mm & 6 & 4.1 & 0.613 & 15.04 & 3.3 & 5.1 \\
Autozooecial aperture width, mm & 50 & 0.29 & 0.031 & 10.58 & 0.23 & 0.34 \\
Autozooecial aperture spacing, mm & 50 & 0.51 & 0.072 & 14.13 & 0.35 & 0.65 \\
Vesicle diameter, mm & 50 & 0.12 & 0.029 & 24.54 & 0.05 & 0.19 \\
Vesicles per aperture & 16 & 11.7 & 0.873 & 7.47 & 10.0 & 13.0 \\
Vesicle spacing, mm & 50 & 0.12 & 0.033 & 26.52 & 0.07 & 0.24 \\
Lunarium length, mm & 29 & 0.16 & 0.042 & 26.36 & 0.08 & 0.24 \\
Lunarium width, mm & 29 & 0.24 & 0.036 & 15.28 & 0.16 & 0.31 \\
Lunarium thickness, mm & 29 & 0.11 & 0.025 & 23.33 & 0.06 & 0.15 \\
\hline
\end{tabular}

1987 Fistuliramus xianzaensis Liu and Wang, p. 5, pl. 2, figs. 2a-c, pl. 3, fig. 1a-c.

Material. SMF 23.036-SMF 23.050.

Description. Branched colonies $5.9-8.3 \mathrm{~mm}$ in diameter, with $3.3-5.1 \mathrm{~mm}$ wide endozones and $1.1-2.3 \mathrm{~mm}$ wide exozones. Autozooecia long in endozones, bending at low angles in exozones. Autozooecial diaphragms few, thin, planar, or concave, concentrated in the transition zone between endozone and exozone. Autozooecial apertures rounded. Lunaria well-developed, horseshoeshaped, originating in endozone, consisting of granular material. Vesicles abundant both in endozone and exozone, moderately large, box-like, polygonal in tangential section, having flattened roofs, separating autozooecia in 1-3 rows and 1013 surrounding each autozooecial aperture; in endozone usually twice as high as those in exozone. Autozooecial walls granular prismatic, $0.005-0.010 \mathrm{~mm}$ thick. Maculae not observed. Granular skeleton on colony surface poorly developed.

Remarks. Fistuliramus xianzaensis Liu and Wang, 1987 is similar to F. bifidus Yang and Xia, 1975 from the Lower Permian of China, but differs by wider branches $(5.9-8.3 \mathrm{~mm}$ vs. $3.2-5.6 \mathrm{~mm}$ in $F$. bifidus) and by larger and more abundant vesicles (average vesicle diameter $0.12 \mathrm{~mm}$ vs. $0.09 \mathrm{~mm}$ in $F$. bifidus). Fistuliramus xianzaensis differs from $F$. elevatus Liu and Wang, 1987 from the Lower Permian of China in larger autozooecial apertures (average aperture width $0.29 \mathrm{~mm}$ vs. $0.19 \mathrm{~mm}$ in $F$. elevatus).

Occurrence. Xiala Formation, ?Middle Permian; Xainza, southwestern Tibet. Zhongba Formation, Permian (upper Cisuralian-Guadalupian); Zhongba area of southwestern Tibet.

\section{Genus ERIDOPORA Ulrich, 1882}

Type species. Eridopora macrostoma Ulrich, 1882. Lower Carboniferous; North America.

Diagnosis. Thin encrusting colonies. Oval apertures with strongly developed lunaria of distinct triangular shape. Cylindrical autozooecia with thin walls and complete diaphragms. Vesicular skeleton consists of angular vesicles.

Remarks. Eridopora Ulrich, 1882 differs from Fistulipora M'Coy, 1849 and Dybowskiella Waagen and Wentzel, 1886 in having large triangular lunaria instead of horseshoe-shaped ones, and predominantly encrusting colonies.

Occurrence. Devonian to Permian; worldwide.

Eridopora uncata Yang and Lu, 1983 Figures 5.4-6, 6.1-3; Table 6

1983 Eridopora ? uncata Yang and Lu, 269, pl. 5, fig. 5; pl. 6, figs. 1-4.

Material. SMF 23.051-SMF 23.052.

Description. Thin encrusting colony. Autozooecia growing from thin epitheca, bending in the early exozone to the colony surface. Basal diaphragms abundant. Autozooecial apertures circular to oval. Lunaria well-developed, triangular; ends of lunaria indenting into autozooecia on the opposite side of the aperture. Vesicles small to large, separating autozooecia in 1-2 rows, 11-16 surrounding each autozooecia aperture, with rounded roofs, polygonal in tangential section. Autozooecial walls granular prismatic, $0.005-0.010 \mathrm{~mm}$ thick. Maculae not observed.

Remarks. Eridopora uncata Yang and Lu, 1983 differs from E. triangulariformis Yang and Lu, 1983 from the Kankerin Formation (Upper Carboniferous) of Kalpin (Western Xinjang, China) in smaller autozooecia $(0.18-0.37 \mathrm{~mm}$ vs. $0.25-0.40 \mathrm{~mm}$ in E. triangulariformis). Eridopora uncata differs from 

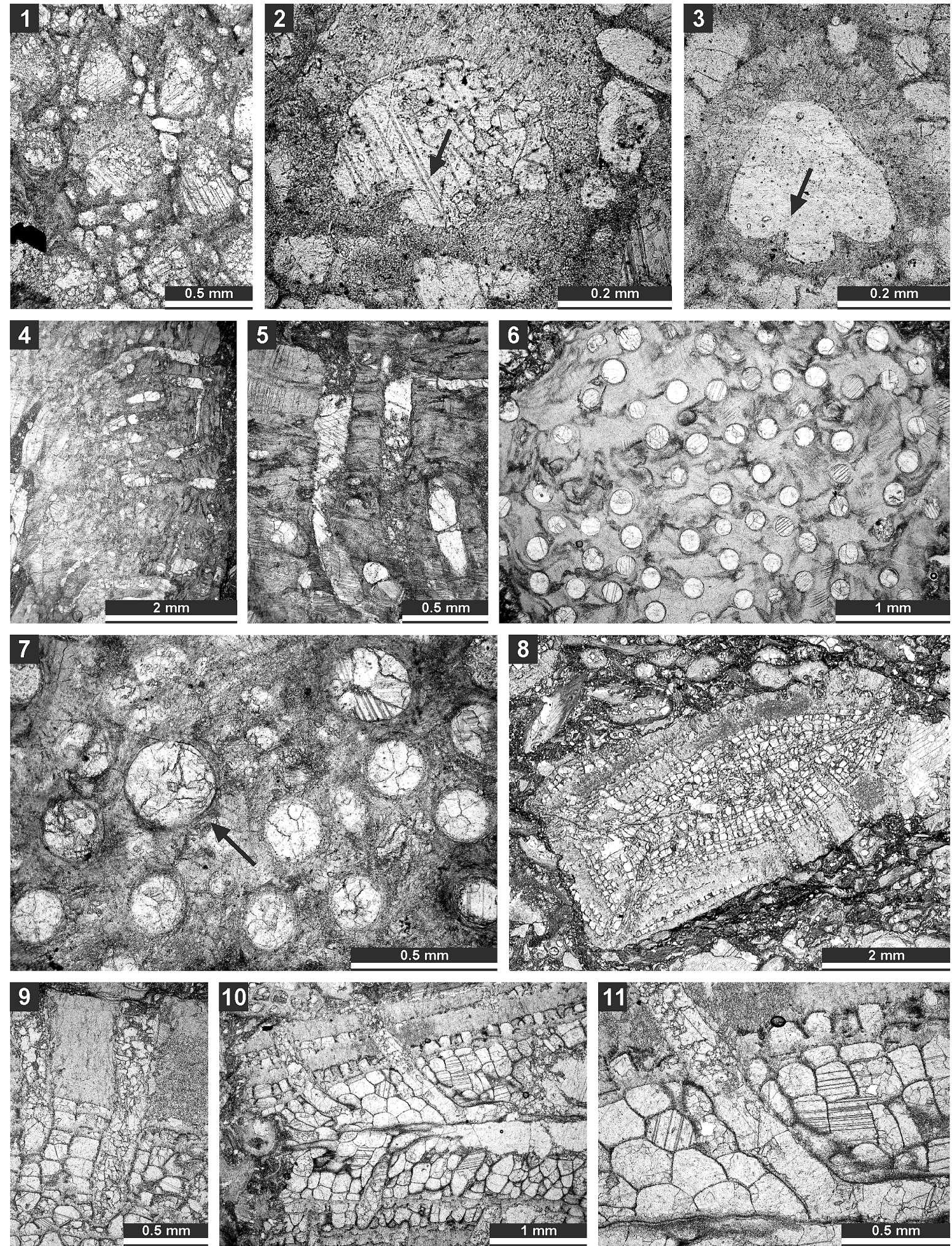

FIGURE 6. Thin section photographs of Eridopora uncata Yang and Lu, 1983, SMF 23.052 (1-3); Cyclotrypa alexanderi Sakagami, 1963 SMF 23.056 (4-5), SMF 23.061 (6), and SMF 23.056 (7); and Hexagonella kobayashii Sakagami, 1968, SMF 23.069 (8-9) and SMF 23.070 (10 and 11). 1-3, tangential section showing autozooecial apertures with lunarial ends indenting into the aperture (arrow); 7 , tangential section showing autozooecia and macrozooecia (arrow); 8 and 9, branch transverse section showing autozooecial chambers and vesicular skeleton; and 10 and 11, longitudinal section showing autozooecial chambers and vesicular skeleton. 
TABLE 6. Measurements of Eridopora uncata Yang and Lu, 1983. Abbreviations as for Table 1.

\begin{tabular}{lcccccc}
\hline & N & X & SD & CV & MIN & MAX \\
\hline Autozooecial aperture width, mm & 31 & 0.26 & 0.046 & 17.72 & 0.18 & 0.37 \\
Autozooecial aperture spacing, mm & 31 & 0.47 & 0.068 & 14.39 & 0.33 & 0.62 \\
Vesicle diameter, mm & 31 & 0.09 & 0.024 & 25.76 & 0.05 & 0.15 \\
Vesicles per aperture & 10 & 13.7 & 1.703 & 12.43 & 11.0 & 16.0 \\
\hline
\end{tabular}

TABLE 7. Measurements of Cyclotrypa alexanderi Sakagami, 1963. Abbreviations as for Table 1.

\begin{tabular}{lcccccc}
\hline & $\mathbf{N}$ & $\mathbf{X}$ & SD & CV & MIN & MAX \\
\hline Autozooecial aperture width, mm & 50 & 0.20 & 0.017 & 8.71 & 0.17 & 0.25 \\
Autozooecial aperture spacing, mm & 50 & 0.39 & 0.050 & 12.86 & 0.27 & 0.50 \\
Vesicle diameter, mm & 50 & 0.13 & 0.029 & 22.74 & 0.07 & 0.18 \\
Vesicles per aperture & 22 & 7.64 & 1.432 & 18.76 & 5.0 & 11.0 \\
Maculae diameter, mm & 11 & 0.6 & 0.163 & 26.67 & 0.4 & 0.9 \\
Macrozooecial aperture width, mm & 7 & 0.31 & 0.041 & 13.25 & 0.25 & 0.36 \\
\hline
\end{tabular}

E. oculata Bassler, 1929 in less closely spaced apertures (average distance between aperture centres $0.47 \mathrm{~mm}$ vs. $0.40 \mathrm{~mm}$ in E. oculata) and in absence of ridges between autozooecial apertures. Occurrence. Baliqliq Group, Lower Permian; Kalpin, Western Xinjiang, China. Zhongba Formation, Permian (upper Cisuralian-Guadalupian); Zhongba area of southwestern Tibet.

\section{Genus CYCLOTRYPA Ulrich, 1896}

Type species. Fistulipora communis Ulrich, 1890. Middle Devonian; lowa, USA.

Diagnosis. Encrusting colonies, often with multiple overgrowths. Cylindrical autozooecia with thin walls and complete diaphragms. Autozooecial apertures rounded. Lunaria absent. Autozooecia separated by vesicular skeleton. Acanthostyles occurring in roofs of vesicles. Low maculae often developed.

Remarks. Cyclotrypa Ulrich, 1896 differs from Fistulipora M'Coy, 1849 and Eridopora Ulrich, 1882 in the absence of lunaria.

Occurrence. Silurian to Permian; Europe, North America, Asia.

Cyclotrypa alexanderi Sakagami, 1963

Figure 6.4-7; Table 7

1963 Cyclotrypa alexanderi Sakagami, p. 206, pl. 12, figs. 1-7.

1976 Cyclotrypa alexanderi Sakagami, 1963; Sakagami, pl. 25, figs. 1-2.

Material. SMF 23.053-SMF 23.066.

Description. Colonies branched ramose or encrusting. Branched colonies 7.5-9.6 $\mathrm{mm}$ in diameter, with 1.2-1.3 $\mathrm{mm}$ wide exozone and 5.1$7.0 \mathrm{~mm}$ wide endozones. Encrusting colonies 1.3-
$1.9 \mathrm{~mm}$ thick. In branched colonies, cylindrical autozooecia long in endozones, bending sharply in exozones, rounded-polygonal in transverse section. In secondary overgrowths and encrusting sheets, autozooecia growing from laminated epitheca. Epitheca 0.025-0.030 mm thick. Autozooecial diaphragms few to common. Autozooecial apertures rounded to oval. Granular material welldeveloped at colony surface. Acanthostyles in granular material developed, $0.05-0.07 \mathrm{~mm}$ in diameter. Locally macrozooecia occurring. Vesicular skeleton well-developed. Vesicles small, separating autozooecia in 1-2 rows, 5-11 surrounding each autozooecial aperture, with rounded roofs, polygonal in tangential section. Autozooecial walls granular prismatic, $0.003-0.008 \mathrm{~mm}$ thick. Low maculae without autozooecia regularly spaced on colony surface, $0.4-0.9 \mathrm{~mm}$ in diameter.

Remarks. Cyclotrypa alexanderi Sakagami, 1963 differs from C. uralica Nikiforova, 1939 from the Lower Permian (Artinskian) of Urals in smaller autozooecial apertures (aperture width 0.17-0.25 $\mathrm{mm}$ vs. $0.35 \mathrm{~mm}$ in C. uralica). Cyclotrypa alexanderi differs from C. exposita Gorjunova, 1975 from the Lower Permian (Artinskian) of Pamir in smaller autozooecial apertures (aperture width 0.17-0.25 $\mathrm{mm}$ vs. $0.35-0.40 \mathrm{~mm}$ in C. exposita).

Occurrence. Noonkanbah Formation, Lower Permian (upper Artinskian-Kungurian); Western Australia (unpublished data). Lower Permian (Artinskian); Malaysia. Zhongba Formation, Permian (upper Cisuralian-Guadalupian); Zhongba area of southwestern Tibet.

Suborder HEXAGONELLINA Morozova, 1970 Family HEXAGONELLIDAE Crockford, 1947 


\section{Genus HEXAGONELLA Waagen and Wentzel,} 1886

Type species. Hexagonella ramosa Waagen and Wentzel, 1886. Upper Permian; Pakistan.

Diagnosis. Colonies consisting of compressed to subcylindrical bifoliate branches. Mesotheca straight, three-layered, with central granular and granular-prismatic outer layers. Autozooecia recumbent, widely isolated by vesicular skeleton throughout the colony. Diaphragms rare, planar. Lunaria well-developed in exozone, consisting of granular-prismatic material. Vesicles large, irregular in endozone, box-like in inner exozone, blisterlike and low in outer exozone. Stereom of granularprismatic material well-developed, containing tubules. Autozooecial walls granular-prismatic. Monticules consisting of central cluster of vesicular skeleton and radiating rows of autozooecia with lunaria directed towards the centre of the monticule. Each monticule surrounded by elevated ridges of vesicular skeleton producing hexagonal pattern.

Remark. Hexagonella Waagen and Wentzel, 1886 differs from Coscinotrypa Hall and Simpson, 1887 by colony form and presence of crests on the colony surface. Some species placed in Hexagonella do not have typical crests of the colony surface (e.g., H. australis \{Bretnall, 1926]).

Occurrence. Twenty-five species have been reported from the Permian of Australia, Asia, and Northern Russia. The genus seems to be absent in North and South America.

Hexagonella kobayashii Sakagami, 1968 Figures 6.8-11, 7.1-4; Table 8

1968 Hexagonella kobayashii Sakagami, p. 50-51, pl. 9, figs. 3-5; 1976, pl. 25, figs. 7-9.

1976 Hexagonella kobayashii Sakagami, 1968; Sakagami, pl. 25, figs. 7-9.

1997 Hexagonella kobayashii Sakagami, 1968; Sakagami and Pillevuit, p. 206, figs. 2.4-5, 3.1-3.

2008 Hexagonella kobayashii Sakagami, 1968; Ernst, Weidlich and Schäfer, p. 680-682, figs. 3.5, 3.7, 3.8, 4.1 .

Material. Six thin sections of single colony SMF 23.067-SMF 23.072.

Description. Free-branched bifoliate colony. Branches elliptical in transverse section, 6.9-8.6 $\mathrm{mm}$ wide and 3.0-4.5 mm thick. Mesotheca straight, three-layered, $0.05-0.10 \mathrm{~mm}$ thick, containing median tubules. Autozooecia long, tubular, bending gently in exozone. Apertures rounded to oval. Lunaria distinct. Diaphragms rare, 1-2 in each autozooecium, thin, planar. Vesicles large, box-like with rounded roofs, separating autozooecia in 2-3 rows, 8-10 surrounding each autozooecia aperture. Autozooecial walls granular, 0.008$0.018 \mathrm{~mm}$ thick. Thick layer of granular skeleton in the outermost exozone. Crests on the colony surface building regular hexagonal patterns. Maculae not observed.

Remarks. Hexagonella kobayashii Sakagami, 1968 is similar to $H$. turgida Bassler, 1929 from Permian of Timor. The latter species differs in having smaller autozooecial apertures (ca. $0.20 \mathrm{~mm}$ vs. $0.19-0.25 \mathrm{~mm}$ in $H$. kobayashii).

Occurrence. Rat Buri Limestone (Khao Phrick), Lower Permian (Artinskian); Thailand. Aseelah Unit, Saal Formation, Lower-?Middle Permian; Batain Coast (eastern Oman). Zhongba Formation, Permian (upper Cisuralian-Guadalupian); Zhongba area of southwestern Tibet.

\section{Family GONIOCLADIIDAE Waagen and Pichl, 1885 \\ Genus GONIOCLADIA Etheridge, 1876}

Type species. Carinella cellulifera Etheridge, 1873. Lower Carboniferous; Carluke (Scotland).

Diagnosis. Reticulate colonies with polygonal fenestrules. Branches bifoliate, joined by anastomoses or rarely by dissepiments. Autozooecia in two or more rows on each side of the mesotheca. Apertures with more or less developed lunaria and apertural styles. Thin mesotheca protruding as ridge on the circular reverse side and as sharp keel on peaked obverse side. Median rods in mesotheca usually lacking, in few species present. Thin walled autozooecia usually separated by vesicular skeleton.

Remarks. Goniocladia Etheridge, 1876 differs from Ramipora Toula, 1875 in having reticulate colony shape instead of pinnate one (consisting of main branch with diverging lateral branches).

Occurrence. Carboniferous-Permian; worldwide.

Goniocladia aff. indica Waagen and Pichl, 1885 Figures 7.5-7, 8.1-7; Table 9

aff. 1885 Goniocladia indica Waagen and Pichl, p. 805, pl. 93, fig. 3.

aff.? 1929 Goniocladia indica Waagen and Pichl, 1885; Bassler, p. 88.

aff.? 1957 Goniocladia indica Waagen and Pichl, 1885; Crockford, p. 38.

aff. 1981 Goniocladia indica Waagen and Pichl, 1885; Yang, Lu and Xia, p. 92-93, pl. 1, fig. 5, pl. 3, fig. 4.

aff. 1986 Goniocladia cf. indica Waagen and Pichl, 1885; Xia, pl. 11, figs. 1-2. 

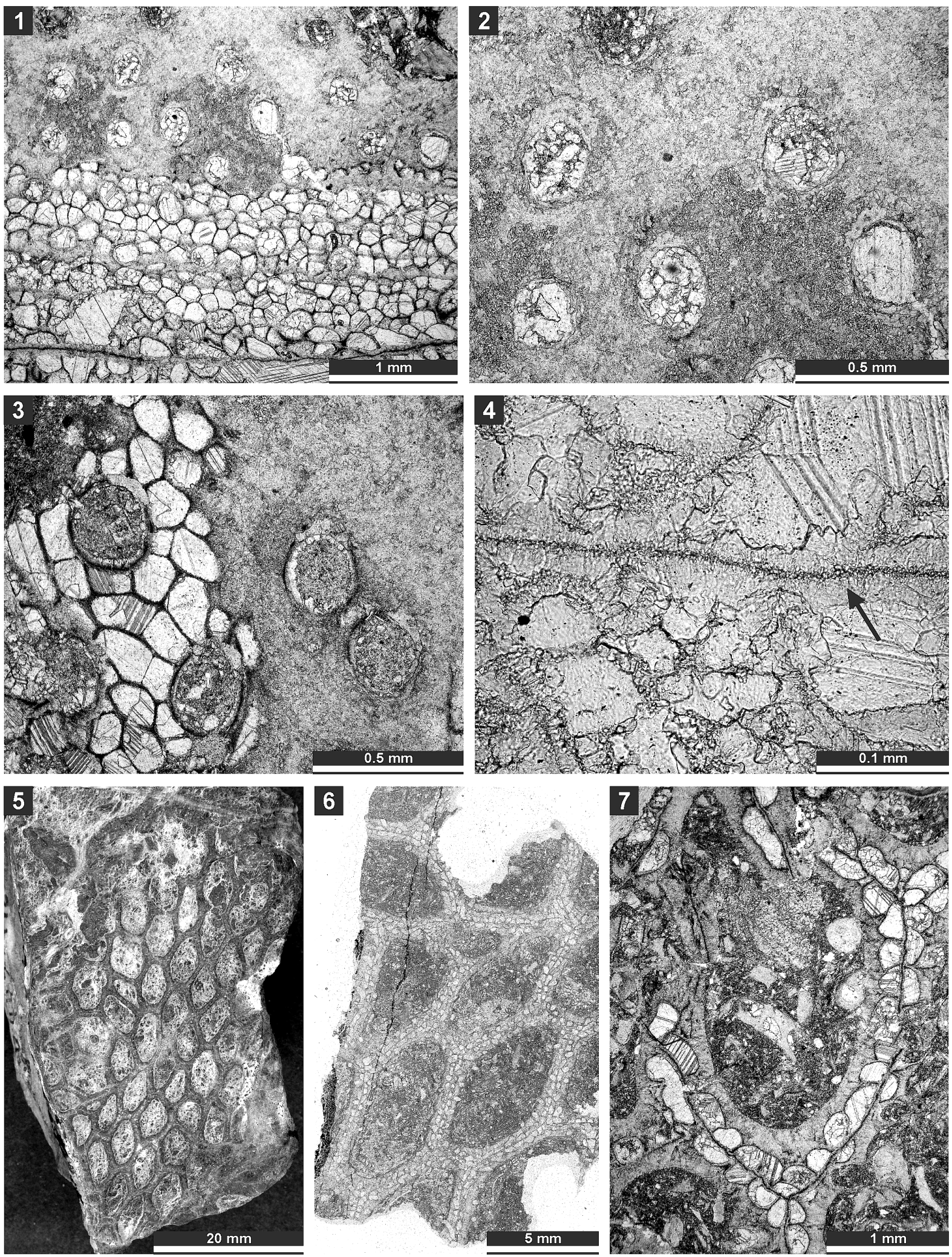

FIGURE 7. Thin section photographs of Hexagonella kobayashii Sakagami, 1968, SMF 23.067 (1-3) and SMF 23.072 (4); and Goniocladia aff. indica Waagen and Pichl, 1885, SMF 23.266 (5), SMF 23.077 (6), and SMF 23.073 (7). 1-3 and 6, tangential section; 7 , mid-tangential section showing autozooecial chamber; 4 , transverse section showing mesotheca with median tubules (arrow); and 5 , external view of the colony form the reverse side. 
TABLE 8. Measurements of Hexagonella kobayashii Sakagami, 1968. Abbreviations as for Table 1.

\begin{tabular}{lcccccc}
\hline & $\mathbf{N}$ & $\mathbf{X}$ & SD & CV & MIN & MAX \\
\hline Autozooecial aperture width, mm & 22 & 0.22 & 0.016 & 7.15 & 0.19 & 0.25 \\
Autozooecial aperture spacing, mm & 22 & 0.53 & 0.047 & 8.81 & 0.42 & 0.60 \\
Vesicle diameter, mm & 30 & 0.12 & 0.031 & 25.96 & 0.04 & 0.19 \\
Vesicles per aperture & 10 & 9.0 & 0.667 & 7.41 & 8.0 & 10.0 \\
Vesicle spacing, mm & 13 & 0.10 & 0.023 & 23.09 & 0.07 & 0.14 \\
\hline
\end{tabular}

aff. 1991 Goniocladia indica Waagen and Pichl, 1885; Xia, p. 191, pl. 7, fig. 10.

Material. SMF 23.073-SMF 23.080, SMF 23.266. Diagnosis. Reticulate colony consisting of anastomosing bifoliate branches of intermediate width and thickness; fenestrules oval to circular, intermediate in size; autozooecia arranged in 4-6 rows on branches; autozooecial apertures with lunaria; vesicular skeleton well-developed, consisting of small vesicles; extrazooecial skeleton well-developed.

Description. Reticulate colony consisting of anastomosing bifoliate branches. Branches 0.88-2.00 $\mathrm{mm}$ wide and 0.63-1.26 mm thick. Fenestrules oval to polygonal (pentagonal to hexagonal), occasionally nearly circular. Autozooecia tubular, semicircular in transverse section at their bases, relatively short, budding in 4-6 rows from each side of thin mesotheca, opening on both sides of the median carina. Superior hemisepta positioned on the distal side of the autozooecial chamber near its bend; inferior hemisepta positioned on the proximal side (at mesotheca). Basal diaphragms rare. Mesotheca straight or slightly undulating, consisting of granular-prismatic material, with dark median layer, 0.02-0.04 $\mathrm{mm}$ thick, protruding on the obverse side as a median carina and as a sharp keel on the reverse side. Autozooecial apertures arranged regularly in 2-6 diagonal rows on both sides of the median carina, rounded to oval. Outermost parts of median lamina containing median rods, $0.010-0.015 \mathrm{~mm}$ in diameter. Lunaria moderately developed, directed towards median carina. Autozooecial walls 0.02-0.04 mm thick, granular-prismatic. Extrazooecial skeleton (stereom) granular. Vesicular skeleton consisting of low small vesicles with flattened roofs, concentrated mostly in endozone.

Remarks. The present material superficially resembles the species Goniocladia indica Waagen and Pichl, 1885, originally described from the Productus Limestone (?Kungurian-Wordian) of Salt Range, Pakistan. The original description of this species is based on external characters without use of thin sections. Only figure $3 e$ from plate 93 (Waagen and Pichl, 1885) shows a broken piece of branch, which reveals zooecial shape and vesicular skeleton typical for Goniocladia. Some important measurements such as aperture size and spacing of the original material are also unknown. Therefore, the assignment to this species by later authors was justified according to external parameters. Waagen and Pichl (1885, p. 805-806) provided the following measurements: branch width ca $1.5 \mathrm{~mm}$, fenestrule length $3-7 \mathrm{~mm}$, and fenestrule width 1-4 $\mathrm{mm}$. They correspond in general with those of the present material. However, the present material possesses superior and inferior hemisepta, which were neither mentioned nor depicted in the original material.

The present species is, therefore, only tentatively assigned with Goniocladia indica Waagen and Pichl, 1885. It differs from G. afghana (Termier and Termier, 1971) from the Lower Permian of Afghanistan and Iran (Ernst and Gorgij, 2013) by larger fenestrules (fenestrule length 4.3-6.9 mm vs. $1.26-2.73 \mathrm{~mm}$ in $\mathrm{G}$. afghana; fenestrule width 2.4-3.7 $\mathrm{mm}$ vs. $0.75-1.56 \mathrm{~mm}$ in G. afghana). Moreover, the present species has wider spaced apertures (average aperture spacing $0.60 \mathrm{~mm}$ vs. $0.45 \mathrm{~mm}$ in $\mathrm{G}$. afghana).

The present species differs from Goniocladia yongzhuensis Liu and Wang, 1987 from the Lower Permian (Artinskian) of Tibet in possessing smaller autozooecial apertures (aperture width 0.15-0.22 $\mathrm{mm}$ vs. $0.20-0.24 \mathrm{~mm}$ in G. yongzhuensis) and larger fenestrules (fenestrule length 4.3-6.9 mm vs. $0.64-5.6 \mathrm{~mm}$ in $\mathrm{G}$. yongzhuensis).

Bassler (1929) and Crockford (1957) mentioned Goniocladia indica, but they did not provide either descriptions or illustrations of their material. Chinese citations of Goniocladia indica Waagen and Pichl, 1885 (Yang et al., 1981; Xia 1986, 1991) seem to correspond to the species described here. However, no description mentioned hemisepta.

Occurrence. ?Lower Permian; Tibet. ?Productus Limestone (?Kungurian-Wordian) of Salt-range, Pakistan. ?Lower Permian; Western Australia. 

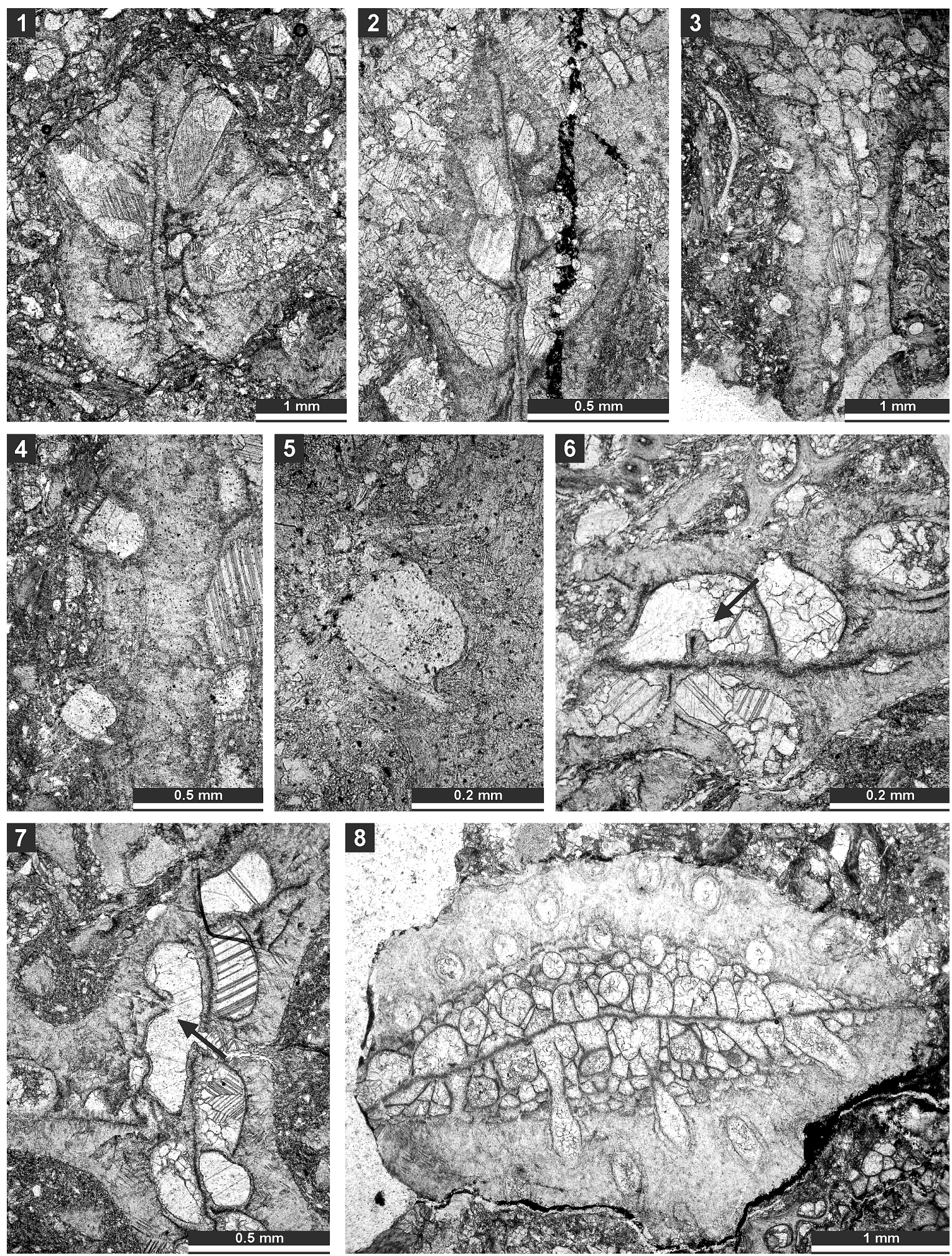

FIGURE 8. Thin section photographs of Goniocladia aff. indica Waagen and Pichl, 1885, SMF 23.076 (1 and 2), SMF 23.077 (3-5), and SMF 23.073 (6 and 7); and Liguloclema meridianus (Etheridge, 1926), SMF 23.093 (8). 1-2, and 6, branch transverse sections showing autozooecia chambers, mesotheca and hemisepta (arrow); 3-5, tangential sections showing autozooecial apertures; 7 , longitudinal section showing autozooecial chamber with superior hemisepta (arrow); and 8, branch oblique section showing mesotheca, autozooecial chambers with hemisepta and vesicular skeleton. 
TABLE 9. Measurements of Goniocladia aff. indica Waagen and Pichl, 1885. Abbreviations as for Table 1.

\begin{tabular}{lcccccc}
\hline & $\mathbf{N}$ & $\mathbf{X}$ & $\mathbf{S D}$ & $\mathbf{C V}$ & MIN & MAX \\
\hline Branch width, mm & 6 & 1.22 & 0.405 & 33.36 & 0.88 & 2.00 \\
Branch thickness, mm & 10 & 0.99 & 0.220 & 22.34 & 0.63 & 1.26 \\
Fenestrule width, mm & 8 & 3.2 & 0.412 & 13.04 & 2.4 & 3.7 \\
Fenestrule length, mm & 8 & 5.8 & 0.989 & 17.03 & 4.3 & 6.9 \\
Distance between branch centres, mm & 8 & 6.5 & 0.316 & 4.82 & 6.0 & 7.0 \\
Distance between dissepiment centres, $\mathrm{mm}$ & 6 & 7.7 & 0.359 & 4.67 & 7.2 & 8.1 \\
Autozooecial aperture width, mm & 20 & 0.19 & 0.022 & 11.29 & 0.15 & 0.22 \\
Autozooecial aperture spacing, mm & 20 & 0.60 & 0.097 & 16.37 & 0.42 & 0.70 \\
Lunarium length, mm & 6 & 0.08 & 0.018 & 21.29 & 0.06 & 0.10 \\
Lunarium width, mm & 6 & 0.14 & 0.019 & 14.03 & 0.10 & 0.15 \\
Lunarium thickness, mm & 5 & 0.03 & 0.009 & 36.19 & 0.02 & 0.04 \\
\hline
\end{tabular}

?Lower Permian; Timor. Zhongba Formation, Permian (upper Cisuralian-Guadalupian); Zhongba area of southwestern Tibet.

Family ETHERELLIDAE Crockford, 1957

Genus LIGULOCLEMA Crockford, 1957

Type species. Liguloclema typicalis Crockford, 1957. Noonkanbah Formation, Lower Permian (Artinskian-Kungurian); Western Australia.

Diagnosis. Colony narrow bifoliate branches, branching dichotomously in plane of mesotheca. Mesotheca consisting of granular-prismatic material, straight; median tubules present. Autozooecia tubular, with rounded to elongate apertures, rhombically arranged on branches, lacking on lateral sides of branches; subquadrate, trapezoid to subhemispherical in transverse section at mesotheca; angular shaped in deep tangential section in mid exozone and partially isolated by vesicles. Long and thin hook-shaped superior hemisepta present, curved proximally, club-shaped. Lunaria absent. Vesicular skeleton well-developed, restricted to exozone; vesicles blister-like, low to moderately high with flat to rounded roofs, polygonal in tangential section. Autozooecial walls granular-prismatic, with dark median zone continuous into boundary zone in mesotheca. Extrazooecial skeleton welldeveloped, displaying cloudy structure; acanthostyles present. Monticules absent.

Remarks. Liguloclema Crockford, 1957 differs from Etherella Crockford, 1957 in having narrow belt-shaped colonies instead of reticulate one in Etherella. Liguloclema differs from Wysejacksonella Ernst and Gorgij, 2013 by the club-shaped hemisepta vs. blunt hemisepta representing buckling of the autozooecial wall at the transition between endo- and exozone in Wysejacksonella.
Furthermore, Liguloclema possesses median tubules in mesotheca.

Occurrence. Lower Permian (Artinskian); Western Australia. Xiala Formation (?Middle Permian); Xainza, southwestern Tibet. ?Lower Permian (Artinskian); Thailand. Zhongba Formation, Permian (upper Cisuralian-Guadalupian); Zhongba area of southwestern Tibet.

Liguloclema meridianus (Etheridge, 1926) Figures 8.8, 9.1-5; Table 10

1926 Sulcoretepora (?) meridianus Etheridge, in Bretnall, p. 19, pl. 1, fig. 9.

1931 Sulcoretepora (?) meridianus Etheridge, 1926; Hosking, p. 15.

1944 "Sulcoretepora" meridianus Etheridge, 1926; Crockford, p. 156, pl. 4, fig. 6, text-figs. 2930.

1957 Liguloclema meridianus (Etheridge, 1926); Crockford, p. 37.

1988 Liguloclema meridianus (Etheridge, 1926); Yanagida, J. a Research Group, p. 17, figs. 2-3.

1987 Liguloclema cf. meridianus (Etheridge, 1926); Liu and Wang, p. 7, figs. 7-8.

1993 Liguloclema meridianus (Etheridge, 1926); Engel and Ross, p. 17, pl. 13, figs. 1-3.

1973 Liguloclema cf. meridianus (Etheridge, 1926); Sakagami, p. 77-78, pl. 11, figs. 1-4.

1999 Liguloclema meridianus (Etheridge, 1926); Sakagami, p. 86-87, pl. 21, figs. 1-3.

Material. SMF 23.081-SMF 23.098.

Description. Colony narrow bifoliate branches, dichotoming in plane of mesotheca. Branches 1.4$3.4 \mathrm{~mm}$ wide and 1.1-1.9 mm thick, lens-shaped in transverse section. Branch edges rounded, lacking autozooecia. Autozooecia tubular, rhombically arranged in 8-13 longitudinal rows on branches, 

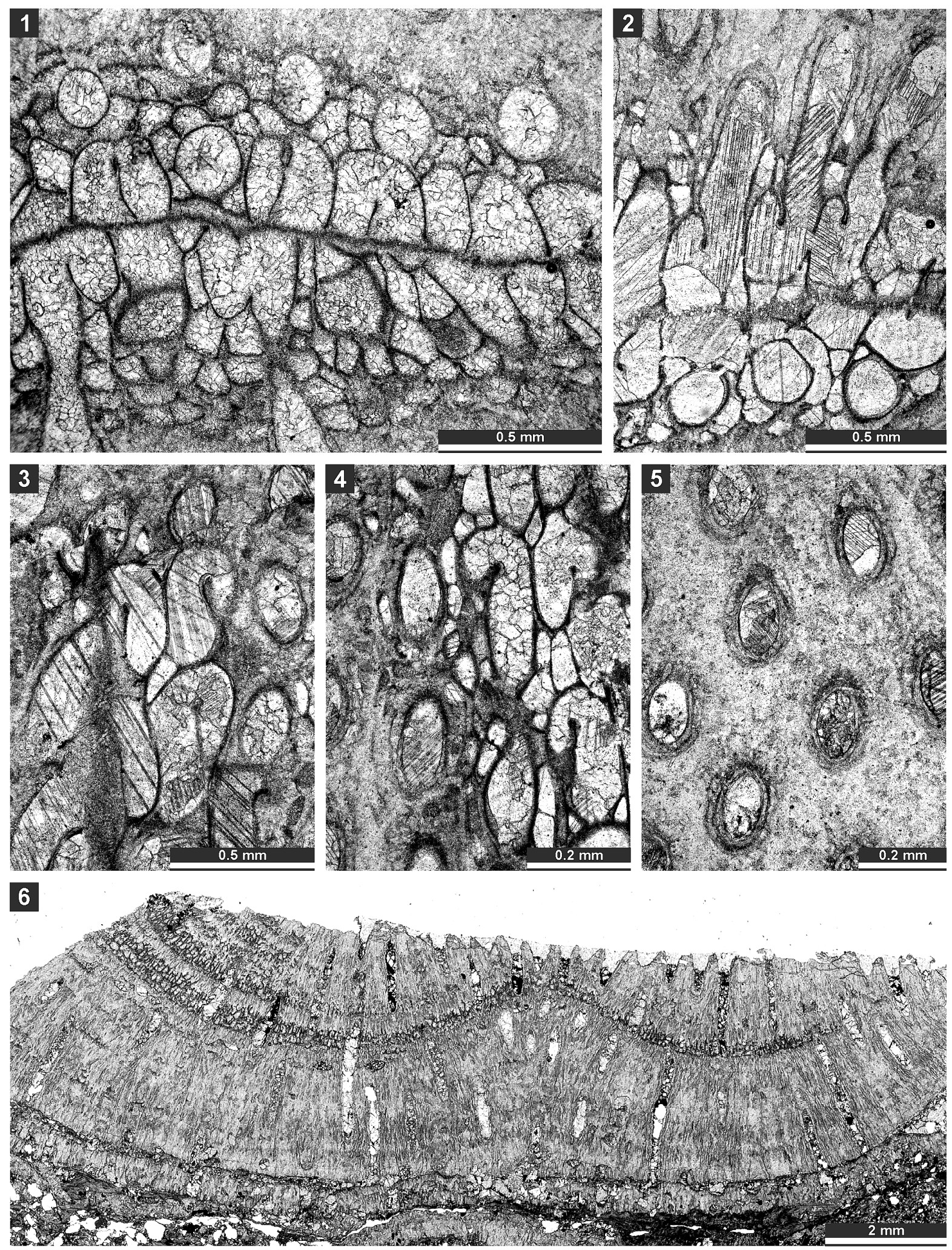

FIGURE 9. Thin section photographs of Liguloclema meridianus (Etheridge, 1926), SMF 23.093 (1), SMF 23.085 (2), and SMF 23.083 (3-5); and Etherella tibetensis n. sp., paratype SMF 23.217 (6). 1 and 2, branch oblique section showing mesotheca, autozooecial chambers with hemisepta and vesicular skeleton; 3 and 4, mid-tangential section showing autozooecial chambers with hemisepta; 5 , tangential section showing autozooecial apertures; and 6 , transverse section showing extrazooecial skeleton and sparse vesicles. 
TABLE 10. Measurements of Liguloclema meridianus (Etheridge, 1926). Abbreviations as for Table 1.

\begin{tabular}{lcccccc}
\hline & N & X & SD & CV & MIN & MAX \\
\hline Autozooecial aperture width, mm & 30 & 0.14 & 0.012 & 8.54 & 0.12 & 0.16 \\
Autozooecial aperture spacing, mm & 30 & 0.65 & 0.105 & 16.17 & 0.52 & 0.95 \\
Aperture spacing diagonally, mm & 30 & 0.47 & 0.045 & 9.59 & 0.37 & 0.55 \\
Vesicle diameter, mm & 30 & 0.08 & 0.018 & 22.51 & 0.05 & 0.12 \\
\hline
\end{tabular}

lacking on lateral sides of branches; subquadrate, trapezoid to subhemispherical in transverse section at mesotheca; angular shaped in deep tangential section in mid exozone and partially isolated by vesicles. Long and thin hook-shaped superior hemisepta present at the transition between endoand exozone, curved proximally, club-shaped. Basal diaphragms rare. Mesotheca consisting of granular-prismatic material, straight, 0.03-0.04 $\mathrm{mm}$ thick; median tubules present, $0.010-0.015$ $\mathrm{mm}$ in diameter; longitudinal ridges absent. Autozooecial walls granular-prismatic, $0.013-0.015$ $\mathrm{mm}$ thick. Autozooecial apertures arranged regularly in 9-13 diagonal rows on branches, rounded to oval. Lunaria absent. Vesicular skeleton welldeveloped, restricted to exozone; vesicles blisterlike, low to moderately high with flat to rounded roofs, polygonal (mainly rectangular) in tangential section. Extrazooecial skeleton well-developed, displaying cloudy structure. Acanthostyles absent. Monticules absent.

Remarks. Two species are placed in the genus Liguloclema, L. typicalis Crockford, 1957 and L. meridianus (Etheridge, 1926), both originally known from the Noonkanbah Formation, Lower Permian (Artinskian-Kungurian) of Western Australia. Crockford (1957, p. 37) provided neither detailed description of $L$. meridianus nor made a comprehensive comparison between $L$. typicalis and $L$. meridianus. The only difference she mentioned was the smaller branch width of $L$. meridianus against $L$. typicalis (less than $1.8 \mathrm{~mm}$ vs. 3.3$5.0 \mathrm{~mm}$ in L. typicalis). The present material of Liguloclema meridianus differs from $L$. typicalis in larger distances between aperture centres (0.52$0.95 \mathrm{~mm}$ vs. $0.43-0.55 \mathrm{~mm}$ in L. typicalis).

Occurrence. Noonkanbah Formation, Lower Permian (upper Artinskian-Kungurian); Western Australia. Rat Buri Limestone, Lower Permian (?Artinskian-Kungurian); Khao Raen, Thailand. Permian, ?Wordian; Khao Hin Kling area, northcentral Thailand. Xiala Formation, ?Middle Permian; Xainza, southwestern Tibet. Zhongba Formation, Permian (upper Cisuralian-Guadalupian); Zhongba area of southwestern Tibet.
Genus ETHERELLA Crockford, 1957

Type species. Etherella porosa Crockford, 1957. Lower Permian, Noonkanbah Formation (Artinskian-Kungurian); Western Australia.

Diagnosis. Reticulate colonies formed by fused branches; branches bifoliate, lenticular, rounded, or oval in transverse section; fenestrules circular to oval. Mesotheca consisting of granular-prismatic material, straight; median tubules present. Autozooecia tubular, with rounded to elongate apertures, rhombically arranged on branches, lacking on lateral sides of branches; subquadrate, trapezoid to subhemispherical in transverse section at mesotheca; angular shaped in deep tangential section in mid exozone and isolated by vesicles and extrazooecial skeleton. Long and thin hook-shaped superior hemisepta present, curved proximally, club-shaped. Lunaria absent. Vesicular skeleton scarcely developed; vesicles small, blister-like, low to moderately high with flat to rounded roofs, polygonal in tangential section. Autozooecial walls granular-prismatic, with dark median zone continuous into boundary zone in mesotheca. Extrazooecial skeleton well-developed, displaying cloudy structure; acanthostyles absent. Monticules absent.

Remarks. Etherella Crockford, 1957 differs from Liguloclema Crockford, 1957 in having reticulate colonies instead of narrow belt-shaped type in Liguloclema. Etherella differs from Wysejacksonella Ernst and Gorgij, 2013 by the club-shaped hemisepta vs. blunt hemisepta representing buckling of the autozooecial wall at the transition between endo- and exozone in Wysejacksonella. Furthermore, Etherella possesses median tubules in mesotheca.

Occurrence. Lower Permian of Australia and Tibet, Upper Permian of the Russian Far East.

Etherella tibetensis n. sp.

Figures 9.6, 10; Table 11

zoobank.org/1610F4FA-934D-4255-ADF6-1DFF0931FBA1

Etymology. The species is named after its occurrence in Tibet.

Holotype. SMF 23.214. 

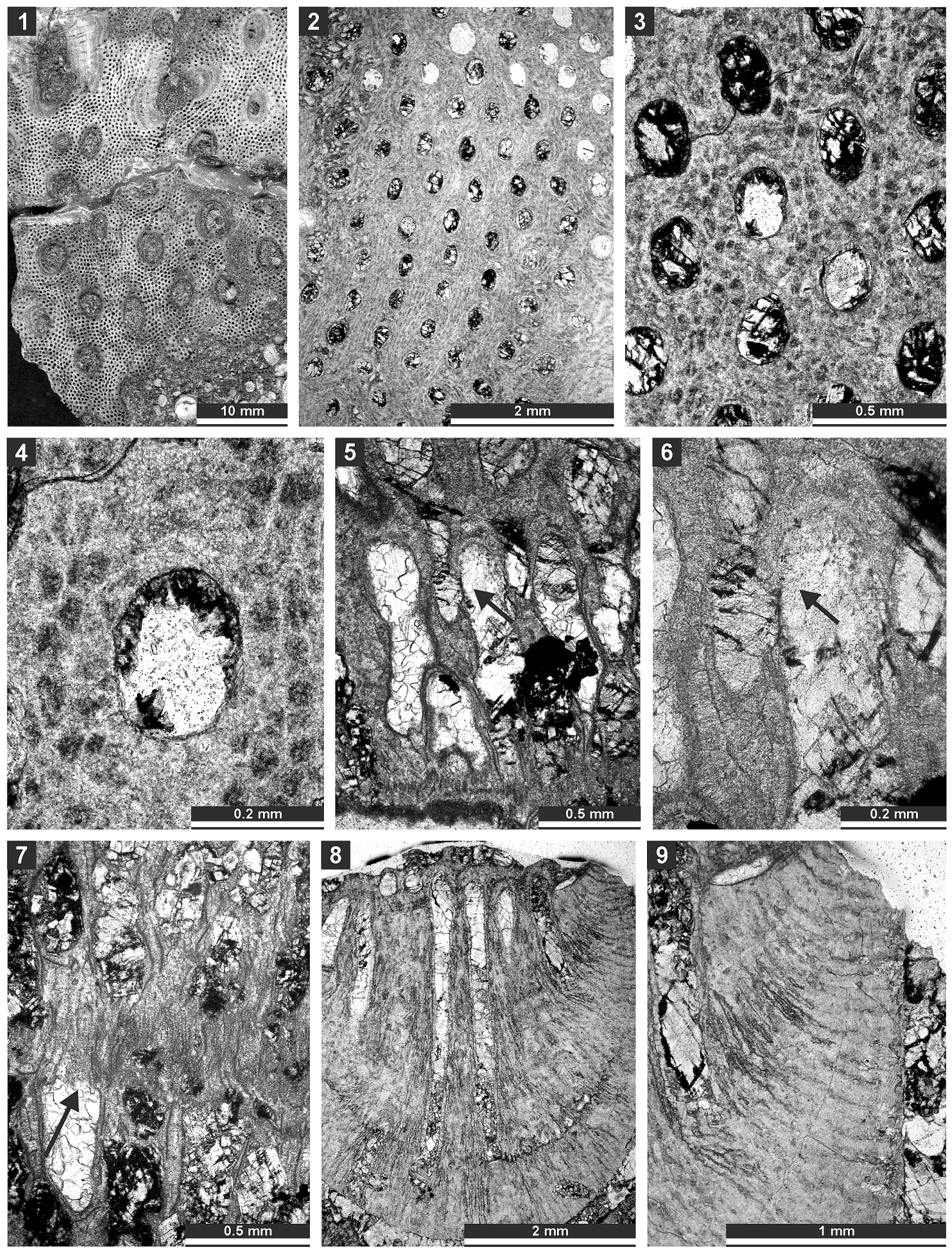

FIGURE 10. Thin section photographs of Etherella tibetensis n. sp., paratype SMF 23.267 (1), paratype SMF 23.216 (2), paratype SMF 23.219 (3 and 4), holotype SMF 23.214 (5-7), and paratype SMF 23.230 (8 and 9). 1, external view of the colony (split along mesotheca); $2-4$, tangential section showing arrangement of autozooecia and wall microstructure; 5-7, oblique section showing hemisepta and mesotheca (arrows); and 8 and 9, branch transverse section showing autozooecial chambers and extrazooecial skeleton. 
TABLE 11. Measurements of Etherella tibetensis $\mathrm{n}$. sp. Abbreviations as for Table 1.

\begin{tabular}{lcccccc}
\hline & $\mathbf{N}$ & $\mathbf{X}$ & SD & CV & MIN & MAX \\
\hline Branch width, mm & 10 & 3.60 & 0.790 & 21.99 & 2.8 & 5.1 \\
Fenestrule width, mm & 20 & 2.33 & 0.477 & 20.50 & 1.6 & 3.3 \\
Fenestrule length, mm & 20 & 3.2 & 0.376 & 11.75 & 2.1 & 4.0 \\
Autozooecial aperture width, mm & 30 & 0.17 & 0.025 & 14.40 & 0.12 & 0.21 \\
Autozooecial aperture spacing along branch, mm & 30 & 0.53 & 0.066 & 12.52 & 0.45 & 0.66 \\
Autozooecial aperture spacing diagonally, mm & 30 & 0.50 & 0.056 & 11.15 & 0.4 & 0.6 \\
Vesicle diameter, mm & 20 & 0.09 & 0.030 & 32.88 & 0.05 & 0.15 \\
\hline
\end{tabular}

Paratypes. SMF 23.215-SMF 23.223, SMF 23.230, SMF 23.231, SMF 23.267.

Type locality. Zhongba area of southwestern Tibet (E 83.76894, N 29.93333).

Type stratum. Zhongba Formation, Permian (upper Cisuralian-Guadalupian).

Diagnosis. Reticulate colonies formed by fused branches; branches bifoliate, lenticular, rounded to oval in transverse section; fenestrules circular to oval; autozooecia arranged in 8-10 rows on branches; lunaria absent; vesicular skeleton scarcely developed, vesicles small; extrazooecial skeleton well-developed; monticules absent.

Description. Studied material represent a bifoliate reticulate colon split in the plane of mesotheca (Figures 9.6, 10.8). Branches 2.8-5.1 mm wide and $8.0-10.3 \mathrm{~mm}$ thick, rounded to oval in transverse section. Fenestrules circular to oval, 1.6-3.3 $\mathrm{mm}$ wide and $2.1-4.0 \mathrm{~mm}$ long. Autozooecia tubular, long, rhombically arranged in 8-10 longitudinal rows on branches, lacking on lateral sides of branches; subquadrate, trapezoid to subhemispherical in transverse section at mesotheca; angular shaped in deep tangential section in mid exozone and partially isolated by vesicles. Long and thin hook-shaped superior hemisepta present at the transition between endo- and exozone, curved proximally, club-shaped. Basal diaphragms rare. Mesotheca consisting of granular-prismatic material, straight, $0.02-0.03 \mathrm{~mm}$ thick; median tubules present, $0.015-0.030 \mathrm{~mm}$ in diameter; Iongitudinal ridges absent. Autozooecial walls granular-prismatic, 0.015-0.040 mm thick. Autozooecial apertures arranged regularly in 9-13 diagonal rows on branches, rounded to oval. Lunaria absent. Vesicular skeleton well-developed, restricted to exozone; vesicles blister-like, low to moderately high with flat to rounded roofs, polygonal in tangential section. Extrazooecial skeleton well-developed, displaying cloudy structure produced by stabshaped elements. Acanthostyles absent. Monticules absent.
Remarks. Etherella tibetensis n. sp. differs from Etherella porosa Crockford, 1957 and E. porosa minor Crockford, 1957 from the Lower Permian (Artinskian-Kungurian) of Western Australia, in having larger and more closely spaced autozooecial apertures as well as an extremely thick extrazooecial skeleton. Etherella tibetensis n. sp. shows intermediate dimensions of colony elements comparable to both Australian species:

Etherella porosa-branch width: $4.0-5.5 \mathrm{~mm}$; fenestrule width: $3.0-5.0 \mathrm{~mm}$; fenestrule length: 5.0-7.0 mm; aperture width: 0.13-0.16 mm; aperture spacing: $0.5-0.7 \mathrm{~mm}$.

Etherella porosa minor-branch width: 2.0-3.3 $\mathrm{mm}$; fenestrule width: $2.0-2.5 \mathrm{~mm}$; fenestrule length: $2.0-3.5 \mathrm{~mm}$; aperture width: $0.14 \mathrm{~mm}$; aperture spacing: $0.50-0.83 \mathrm{~mm}$.

Etherella tibetensis-branch width: 2.8-5.1 $\mathrm{mm}$; fenestrule width: $1.6-3.3 \mathrm{~mm}$; fenestrule length: $2.1-4.0 \mathrm{~mm}$; aperture width: 0.12-0.21 $\mathrm{mm}(0.17 \mathrm{~mm}$ at average); aperture spacing: $0.45-0.66 \mathrm{~mm}$ (0.53 $\mathrm{mm}$ at average).

The species Coscinotrypa orientalis Sakagami, 1968 from the Permian of Khao Ta Mong Rai, Thailand, may belong to Etherella. It shows oval apertures without lunaria, scarce vesicular skeleton and extensive extrazooecial skeleton. However, the presence of the hook-shaped hemisepta cannot be confirmed on that material because the part of the colony at mesotheca is strongly affected by diagenesis. This species also possesses larger autozooecial apertures (average autozooecial width $0.24 \mathrm{~mm}$ vs. $0.17 \mathrm{~mm}$ in E. tibetensis).

Order TREPOSTOMATA Ulrich, 1882

Suborder AMPLEXOPORINA Astrova, 1965

Family STENOPORIDAE Waagen and Wentzel, 1886

Genus TABULIPORA Young, 1883

Type species. Cellepora urii Fleming, 1828. Carboniferous; Scotland. 
Diagnosis. Ramose, encrusting, cylindrical, or massive colonies. Autozooecia with basal diaphragms and ring septa. Autozooecial walls irregularly thickening with development of monilae. Exilazooecia rare. Acanthostyles of two sizes: small microacanthostyles and large macroacanthostyles.

Remarks. The genus Tabulipora Young, 1883 differs from the genera Stenopora Lonsdale, 1844 and Stenodiscus Crockford, 1945 by the development of ring septa.

Occurrence. Carboniferous-Permian; worldwide.

Tabulipora xinjiangensis Yang and Lu, 1983

Figure 11.1-2; Table 12

1983 Tabulipora xinjiangensis Yang and Lu, p. 271, pl. 2, figs. $1-2$.

Material. SMF 23.232-SMF 23.234.

Material. Encrusting colony, $0.75-1.26 \mathrm{~mm}$ thick. Autozooecia prismatic, having polygonal shape in transverse section, containing rare diaphragms and abundant ring septa. Ring septa concentrated in exozones, occupying about a half of the autozooecial chamber space. Acanthostyles 0.05-0.11 $\mathrm{mm}$ in diameter, having narrow hyaline cores and wide laminated sheaths, 1-3 surrounding each autozooecial aperture. Exilazooecia not observed. Endozonal walls granular, $0.015-0.020 \mathrm{~mm}$ thick; exozonal walls monilae-shaped thickened, laminated, serrated, with distinct autozooecial boundaries, $0.075-0.120 \mathrm{~mm}$ thick. Tubules abundant in exozonal walls, $0.010-0.015 \mathrm{~mm}$ in diameter.

Remarks. Tabulipora xinjiangensis Yang and Lu, 1983 differs from T. angjiensis Xia, 1986 from the Ghainaha Formation (Middle Permian) of the Rutog region of Tibet, in possessing fewer acanthostyles and having larger autozooecial apertures (0.25-0.35 $\mathrm{mm}$ vs. $0.15-0.25 \mathrm{~mm}$ in $T$. angjiensis). Tabulipora xinjiangensis differs from $T$. sinensis Yang and Lu, 1984 and T. wangcangensis Yang and Lu, 1984 from the Lower Permian of southwest China in having an encrusting colony instead of a branched colony.

Occurrence. Baliqliq Group, Lower Permian; Kalpin, Western Xinjiang, China. Zhongba Formation, Permian (upper Cisuralian-Guadalupian); Zhongba area of southwestern Tibet.

\section{Family DYSTRITELLIDAE Dunaeva and Morozova, 1967 Genus DYSCRITELLA Girty, 1911}

Type species. Dyscritella robusta Girty, 1911. Lower Carboniferous; Arkansas, USA.

Diagnosis. Dendroid and encrusting colony with abundant acanthostyles and exilazooecia. Autozo- oecia parallel to longitudinal direction of the colony in endozone; gradually bending outward in exozone. Diaphragms in autozooecia lacking or very rare; lacking in exilazooecia. Exilazooecia circular to angular in cross section and separated from the autozooecia and from each other by thick walls. Two sizes of acanthostyles may be present. Zooecial walls thin in endozone, rapidly thickening in the exozone (modified after Ernst and Gorgij, 2013).

Remarks. Dyscritella Girty, 1911 generally lacks diaphragms which are commonly developed in the similar genus Dyscritellina Morozova in Dunaeva and Morozova, 1967.

Occurrence. Devonian to Triassic; worldwide.

Dyscritella lii n. sp.

Figure 11.3-6; Table 13

\section{zoobank.org/C2A7C366-334C-46E5-BB66-375EBFE2FC98}

Etymology. The species is named in honour of Dr. Xianghui $\mathrm{Li}$, who provided material for this study and helped during the manuscript preparation.

Holotype. SMF 23.235.

Paratypes. SMF 23.236 and SMF 23.237.

Type locality. Zhongba area of southwestern Tibet (E 84.31536, N 29.74233).

Type stratum. Zhongba Formation, Permian (upper Cisuralian-Guadalupian).

Diagnosis. Encrusting colony; exilazooecia few; acanthostyles large, abundant, 8-14 surrounding each autozooecial aperture; exozonal walls thick.

Description. Encrusting colony, 0.99-1.05 mm thick, with $0.54-0.64 \mathrm{~mm}$ wide exozone. Autozooecial diaphragms absent. Autozooecial apertures rounded to slightly angular. Exilazooecia few, having rounded to polygonal transverse section, restricted to the exozone, $0.04-0.11 \mathrm{~mm}$ in diameter. Abundant acanthostyles in the walls of the exozone, originating from transitional zone between endozone and exozone, 8-14 surrounding each autozooecial aperture. Walls granular-prismatic, $0.02-0.03 \mathrm{~mm}$ thick in the endozone; laminated, regularly thickened, $0.08-0.13 \mathrm{~mm}$ thick in exozone. Maculae not observed.

Remarks. Dyscritella lii n. sp. differs from Dyscritella phetchabunensis Sakagami, 1975 from the Lower Permian of Thailand, by having larger and more abundant acanthostyles and fewer exilazooecia, as well as larger autozooecia (autozooecial aperture width $0.18-0.30 \mathrm{~mm}$ vs. $0.13-0.17$ $\mathrm{mm}$ in D. phetchabunensis). Dyscritella lii $\mathrm{n}$. sp. differs from D. fida Morozova, 1991 from the Lower Permian of Mongolia in possessing more abundant acanthostyles (8-14 vs. 6-9 around each aperture in D. fida), as well as larger autozooecia (autozo- 

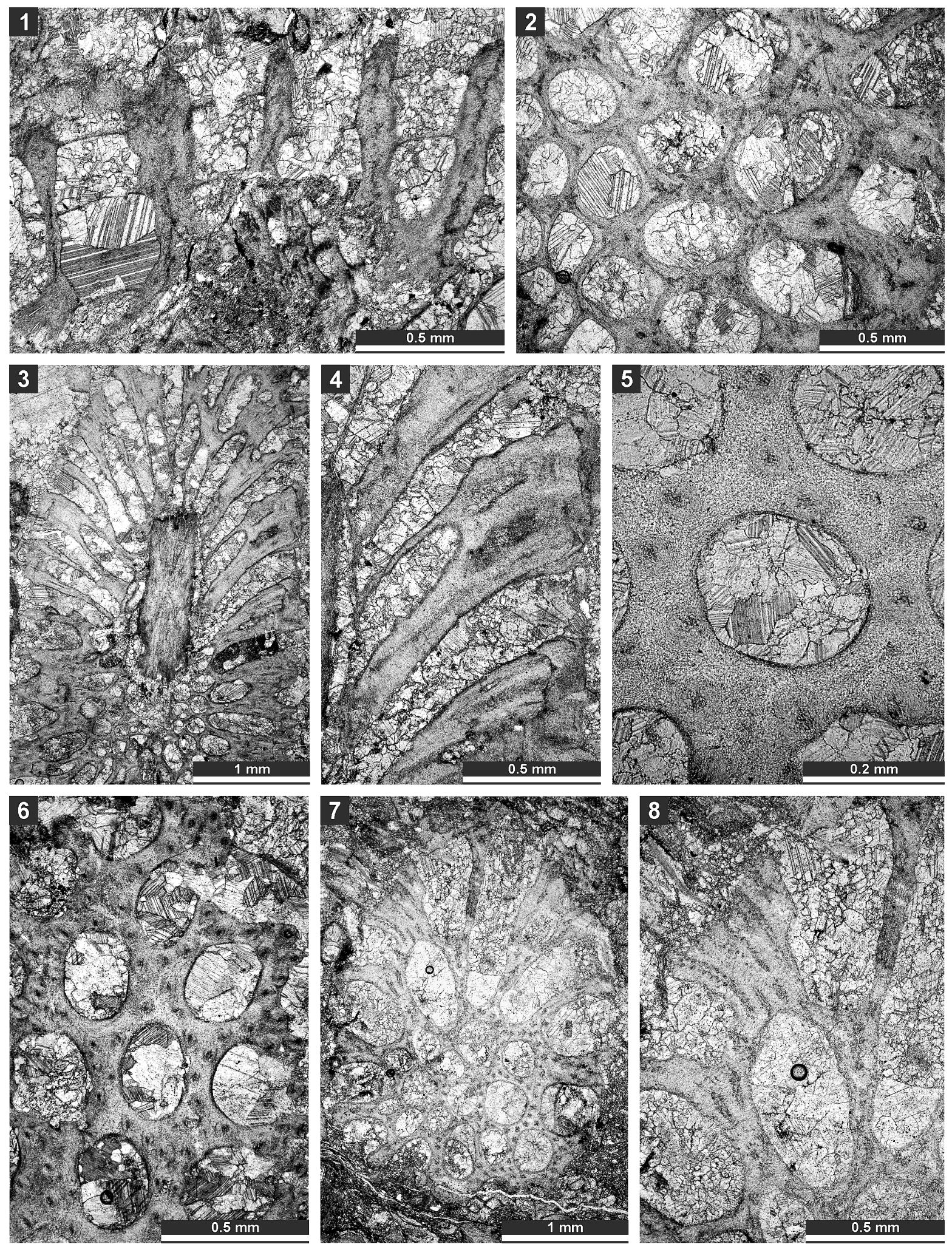

FIGURE 11. Thin section photographs of Tabulipora xinjiangensis Yang and Lu, 1983, SMF 23.233 (1 and 2); Dyscritella lii n. sp., holotype SMF 23.235 (3, 4, and 6) and paratype SMF 23.236 (5); and Ulrichotrypella omanica Ernst et al., 2008, SMF 23.242 (7 and 8). 1, longitudinal section showing ring septa; 2, oblique section showing macroacanthostyles and tubules; 3 and 4 , oblique section through the colony; 5 and 6 , tangential section showing autozooecial apertures and acanthostyles; and 7 and 8, oblique section. 
TABLE 12. Measurements of Tabulipora xinjiangensis Yang and Lu, 1983. Abbreviations as for Table 1.

\begin{tabular}{lcccccc}
\hline & $\mathbf{N}$ & $\mathbf{X}$ & SD & CV & MIN & MAX \\
\hline Autozooecial aperture width, $\mathrm{mm}$ & 12 & 0.30 & 0.027 & 9.19 & 0.25 & 0.35 \\
Autozooecial aperture spacing, $\mathrm{mm}$ & 7 & 0.40 & 0.060 & 15.08 & 0.32 & 0.50 \\
Exozonal wall thickness, $\mathrm{mm}$ & 7 & 0.094 & 0.014 & 14.50 & 0.075 & 0.120 \\
\hline
\end{tabular}

TABLE 13. Measurements of Dyscritella lii n. sp. Abbreviations as for Table 1.

\begin{tabular}{lcccccc}
\hline & N & X & SD & CV & MIN & MAX \\
\hline Autozooecial aperture width, mm & 29 & 0.24 & 0.030 & 12.28 & 0.18 & 0.30 \\
Autozooecial aperture spacing, mm & 22 & 0.38 & 0.057 & 15.06 & 0.26 & 0.48 \\
Acanthostyle diameter, mm & 20 & 0.08 & 0.022 & 28.54 & 0.04 & 0.12 \\
Acanthostyles per aperture & 14 & 10.1 & 1.657 & 16.34 & 8.0 & 14.0 \\
\hline
\end{tabular}

oecial aperture width $0.18-0.30 \mathrm{~mm}$ vs. $0.18-0.20$ $\mathrm{mm}$ in D. fida).

Family ULRICHOTRYPELLIDAE Romantchuk in Romantchuk and Kiseleva, 1968

Genus ULRICHOTRYPELLA Romantchuk, 1967

Type species. Ulrichotrypella prima Romantchuk, 1967. Upper Permian; Khabarovsk region, Russia. Diagnosis. Ramose and rarely encrusting colonies. Autozooecia with circular to polygonal apertures. Diaphragms rare, thin, planar. Autozooecial walls in the exozone irregularly thickened. Exilazooecia rare to common. Abundant aktinotostyles present (modified after Astrova, 1978).

Remarks. Ulrichotrypella Romantchuk, 1967 differs from Ulrichotrypa Bassler, 1929 by the presence of diaphragms in autozooecia and aktinotostyles in the walls of the autozooecia.

Occurrence. Lower Permian-Upper Permian; Indonesia, Iran, Russia, Canada.

Ulrichotrypella omanica Ernst, Weidlich and Schäfer, 2008

Figures 11.7-8, 12.1; Table 14

$2008 \quad$ Ulrichotrypella omanica Ernst, Weidlich and Schäfer, p. 686, figs. 5.12-17.

Material. SMF 23.238-SMF 23.242.

Description. Ramose colony, $2.2 \mathrm{~mm}$ in diameter, with $0.65 \mathrm{~mm}$ wide exozone and $0.9 \mathrm{~mm}$ wide endozone. Thin complete diaphragms in autozooecia constricted to exozone. Autozooecial apertures rounded to angular. Exilazooecia few, having a rounded to polygonal transverse section, restricted to the exozone, $0.09-0.12 \mathrm{~mm}$ in diameter. Abundant aktinotostyles in the walls of the exozone, originating from transitional zone between endozone and exozone. Acanthostyles absent. Walls granular-prismatic, $0.03-0.04 \mathrm{~mm}$ thick in the endozone; laminated, regularly thickened, 0.07$0.15 \mathrm{~mm}$ thick in exozone.
Remarks. Ulrichotrypella omanica Ernst et al., 2008 differs from U. prima Romantchuk, 1967 in having larger apertures $(0.21-0.38 \mathrm{~mm}$ vs. 0.20 $0.29 \mathrm{~mm}$ in U. prima) and less abundant exilazooecia.

Occurrence. Aseelah Unit, Saal Formation, Lower-?Middle Permian; Batain Coast (eastern Oman). Zhongba Formation, Permian (upper Cisuralian-Guadalupian); Zhongba area of southwestern Tibet.

Family ERIDOTRYPELLIDAE Morozova, 1960 Genus NEOERIDOTRYPELLA Morozova, 1970

Type species. Neoeridotrypella pulchra Morozova, 1970. Permian, Guadalupian (Kazanian); Russia.

Diagnosis. Branched colonies with wide exozones. Autozooecia polygonal in transverse section of endozone, bending at low angles in exozone. Autozooecial apertures oval to polygonal. Diaphragms rare. Exilazooecia rare. Autozooecial walls in the exozone irregularly thickened, traversed by tubules. Acanthostyles stellate, variable in size.

Remarks. Neoeridotrypella Morozova, 1970 differs from Permopora Romantchuk, 1967 in being a branched colony rather than an encrusting one.

Occurrence. Permian; Russia, USA, Tibet.

Neoeridotrypella astrica (Linskaya, 1951)

Figure 12.2-7; Table 15

1951 Rhombotrypella astrica Linskaya, p. 150, pl. 3, figs. 3-4.

Material. SMF 23.243-SMF 23.250.

Description. Ramose colonies, $4.10-5.40 \mathrm{~mm}$ in diameter, with $0.54-0.82 \mathrm{~mm}$ wide exozone and 3.02-3.76 mm wide endozone. Autozooecial diaphragms absent. Autozooecial apertures rounded to slightly angular. Exilazooecia few, having rounded to polygonal transverse section shape, restricted to the exozone, $0.04-0.11 \mathrm{~mm}$ in diame- 

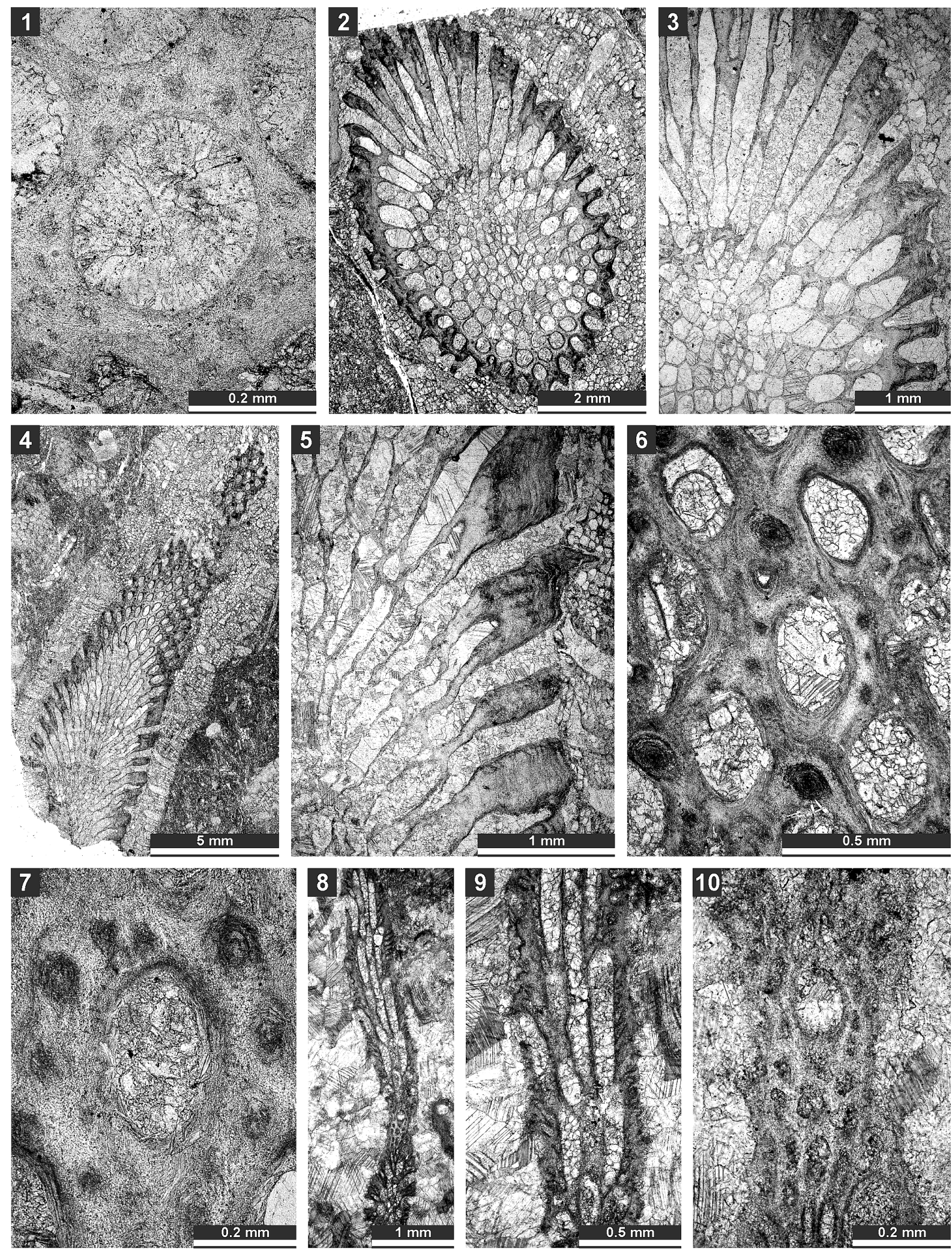

FIGURE 12. Thin section photographs of Ulrichotrypella omanica Ernst et al., 2008, SMF 23.242 (1); Neoeridotrypella astrica (Linskaya, 1951), SMF 23.245 (2 and 3), SMF 23.246 (4-6), and SMF 23.249 (7); and Streblotrypa (Streblotrypa) parviformis n. sp., holotype SMF 23.251 (8-10). 1, 6, 7, and 10, tangential section; $2-5$, oblique branch section; and 8 and 9 , longitudinal section. 
TABLE 14. Measurements of Ulrichotrypa omanica Ernst et al., 2008. Abbreviations as for Table 1.

\begin{tabular}{lcccccc}
\hline & $\mathbf{N}$ & $\mathbf{X}$ & $\mathbf{S D}$ & $\mathbf{C V}$ & MIN & MAX \\
\hline Autozooecial aperture width, mm & 17 & 0.28 & 0.048 & 17.11 & 0.21 & 0.38 \\
Autozooecial aperture spacing, mm & 13 & 0.47 & 0.076 & 16.33 & 0.38 & 0.67 \\
Exozone width, mm & 6 & 0.10 & 0.023 & 23.29 & 0.06 & 0.12 \\
Aktinotostyle diameter, mm & 10 & 0.06 & 0.012 & 21.43 & 0.04 & 0.07 \\
Exozonal wall thickness, mm & 8 & 0.11 & 0.031 & 28.22 & 0.07 & 0.15 \\
\hline
\end{tabular}

TABLE 15. Measurements of Neoeridotrypella astrica (Linskaya, 1951). Abbreviations as for Table 1.

\begin{tabular}{lcccccc}
\hline & $\mathbf{N}$ & $\mathbf{X}$ & $\mathbf{S D}$ & $\mathbf{C V}$ & MIN & MAX \\
\hline Branch width, mm & 4 & 4.66 & 0.550 & 11.79 & 4.10 & 5.40 \\
Exozone width, mm & 4 & 0.65 & 0.136 & 20.94 & 0.54 & 0.82 \\
Endozone width, mm & 4 & 3.36 & 0.305 & 9.07 & 3.02 & 3.76 \\
Autozooecial aperture width, mm & 30 & 0.22 & 0.024 & 11.00 & 0.17 & 0.26 \\
Autozooecial aperture spacing along branch, mm & 30 & 0.47 & 0.051 & 10.85 & 0.40 & 0.57 \\
Macroacanthostyle diameter, mm & 21 & 0.16 & 0.028 & 17.42 & 0.10 & 0.22 \\
Microacanthostyle diameter, mm & 30 & 0.07 & 0.013 & 17.64 & 0.04 & 0.10 \\
\hline
\end{tabular}

ter. Abundant stellate acanthostyles in the walls of the exozone, originating from transitional zone between endozone and exozone, strongly varying in size. Usually 1-4 macroacanthostyles and 5-10 microacanthostyles surrounding each autozooecial aperture. Walls granular-prismatic, $0.018-0.025$ $\mathrm{mm}$ thick in the endozone; laminated, regularly thickened, $0.15-0.26 \mathrm{~mm}$ thick in exozone. Tubules and spherules abundant in exozonal walls. Remarks. Neoeridotrypella astrica (Linskaya, 1951) differs from N. pulchra Morozova, 1970 from the Upper Permian (Kazanian) of Russia, in having slightly larger autozooecial apertures (aperture width $0.17-0.26 \mathrm{~mm}$ vs. $0.16-0.20 \mathrm{~mm}$ in N. pulchra). Neoeridotrypella astrica differs from N. schilti Gilmour et al., 1997 from the Upper Permian (Wordian) of Nevada, USA, in having smaller autozooecial apertures (average aperture width 0.22 $\mathrm{mm}$ vs. $0.25 \mathrm{~mm}$ in N. schilti). Furthermore, Neoeridotrypella astrica has no diaphragms instead of the few present in $N$. schilti, and stellate acanthostyles instead of normal ones.

Occurrence. Cisuralian (Artinskian-Kungurian); Northern Urals, Russia. Zhongba Formation, Permian (upper Cisuralian-Guadalupian); Zhongba area of southwestern Tibet.

Order CRYPTOSTOMATA Vine, 1884

Suborder RHABDOMESINA Astrova and Morozova, 1956

Suborder RHABDOMESINA Astrova and Morozova, 1956

Family HYPHASMOPORIDAE Vine, 1885
Genus STREBLOTRYPA Vine, 1885 Sub-genus STREBLOTRYPA (STREBLOTRYPA) Vine, 1885

Type species. Streblotrypa nicklesi Vine, 1885. Middle Carboniferous; England.

Diagnosis. Branched colonies. Indistinct bundle of about 10 or fewer axial zooecia in the endozone. Autozooecia budding from axial bundle, having long inflated proximal parts, rounded-polygonal in transverse section in the endozone, bending abruptly at the transition between endo- and exozone. Autozooecial apertures rounded to oval. Diaphragms rare.

Hemisepta usually present. Metazooecia usually restricted to rows between the autozooecial apertures; styles usually lacking but poorly developed acanthostyles sometimes occurring. Autozooecial walls laminated, without distinct autozooecial boundaries.

Remarks. Streblotrypa (Streblotrypa) Vine, 1885 differs from S. (Streblascopora) Bassler, 1929 by possessing an indistinctly defined axial bundle of 10 or less axial zooecia. Streblotrypa (Streblotrypa) differs from Hyphasmopora Etheridge, 1875 by the presence of an axial bundle and having a wall structure without distinct autozooecial boundaries.

Occurrence. Carboniferous to Permian; worldwide.

Streblotrypa (Streblotrypa) parviformis $\mathrm{n}$. $\mathrm{sp}$. Figures 12.8-10, 13.1-3; Table 16

zoobank.org/5E091691-0A97-45F9-8BD6-091335B75870 

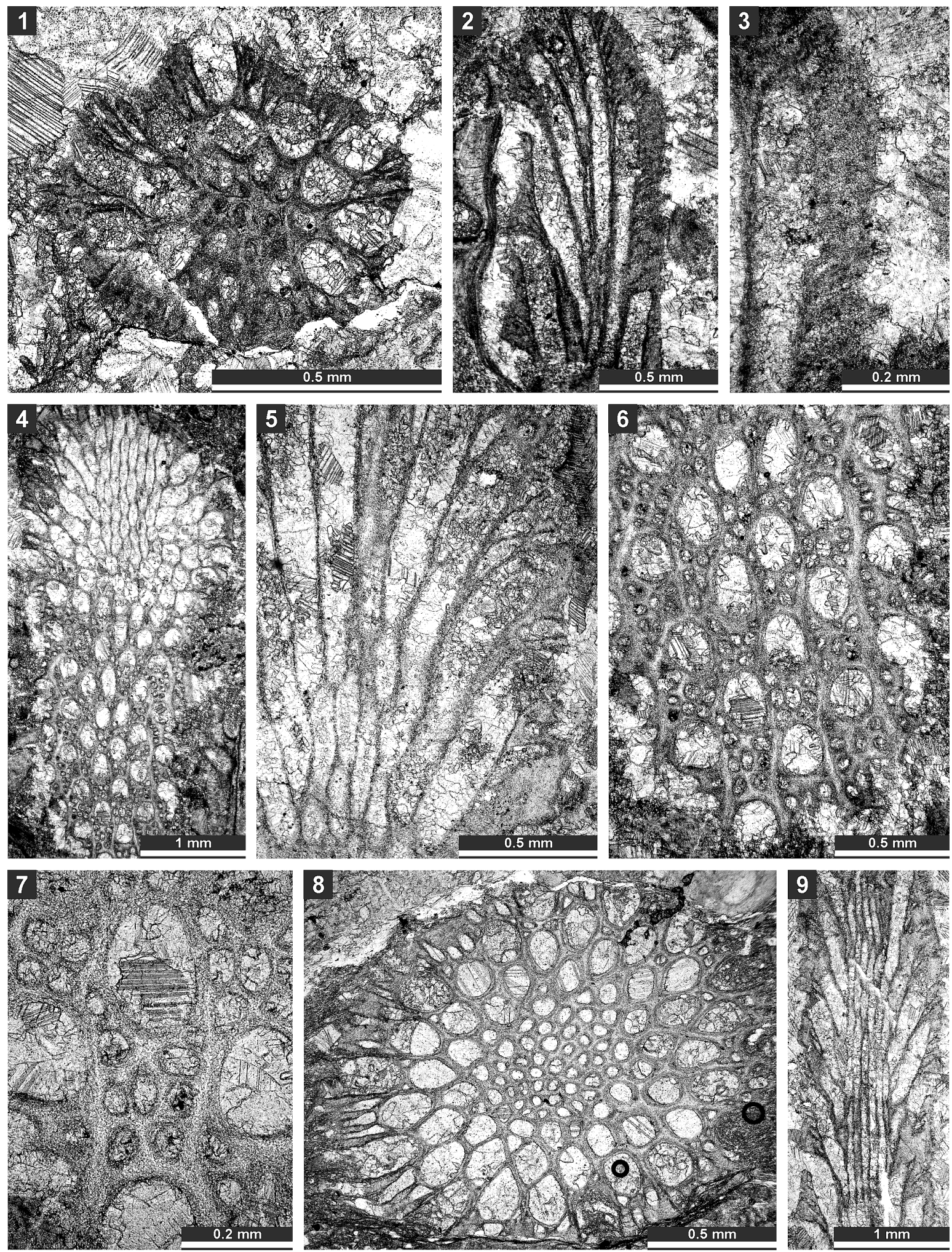

FIGURE 13. Thin section photographs of Streblotrypa (Streblotrypa) parviformis n. sp., paratype SMF 23.260 (1) and paratype SMF 23.256 (2 and 3); Streblotrypa (Streblascopora) delicatula Sakagami, 1961, SMF 23.205 (4, 6, and 7), SMF 23.206 (5), and SMF 23.143 (8); and Streblotrypa (Streblascopora) marmionensis (Etheridge, 1926), SMF 23.145 (9). 1 and 8, branch transverse section; 2, 3, 5, and 9, longitudinal section; 4, branch oblique section; and 6 and 7 , tangential section. 
TABLE 16. Measurements of Streblotrypa (Streblotrypa) parviformis n. sp. Abbreviations as for Table 1.

\begin{tabular}{lcccccc}
\hline & N & $\mathbf{X}$ & SD & CV & MIN & MAX \\
\hline Branch width, mm & 20 & 0.68 & 0.091 & 13.45 & 0.51 & 0.92 \\
Exozone width, mm & 19 & 0.13 & 0.027 & 20.66 & 0.09 & 0.17 \\
Endozone width, mm & 19 & 0.42 & 0.066 & 15.84 & 0.31 & 0.58 \\
Axial bundle width, mm & 17 & 0.15 & 0.039 & 25.61 & 0.10 & 0.26 \\
Autozooecial aperture width, mm & 25 & 0.10 & 0.011 & 11.15 & 0.08 & 0.12 \\
Autozooecial aperture spacing along branch, mm & 4 & 0.53 & 0.059 & 11.20 & 0.48 & 0.61 \\
Autozooecial aperture spacing diagonally, mm & 3 & 0.25 & 0.026 & 10.58 & 0.22 & 0.27 \\
Metazooecia width, mm & 15 & 0.02 & 0.006 & 28.30 & 0.01 & 0.03 \\
\hline
\end{tabular}

Etymology. The species is named after its similarity with Streblotrypa (Streblotrypa) parva Morozova, 1965.

Holotype. SMF 23.251.

Paratypes. SMF 23.131-SMF 23.142, SMF 23.252-SMF 23.261.

Type locality. Zhongba area of southwestern Tibet (E 84.31536, N 29.74233).

Type stratum. Zhongba Formation, Permian (upper Cisuralian-Guadalupian).

Diagnosis. Thin branched colonies; axial bundle consisting of 3-7 axial zooecia; hemisepta absent; 12-20 metazooecia arranged between apertures; acanthostyles present.

Description. Branched colonies, 0.51-0.92 $\mathrm{mm}$ in diameter, with $0.09-0.17 \mathrm{~mm}$ wide exozones and $0.31-0.58 \mathrm{~mm}$ wide endozones. Autozooecia long, tubular, growing from a distinct axial bundle, rounded to slightly polygonal in transverse section. Axial bundle small, formed by 3-7 axial zooecia, $0.10-0.26 \mathrm{~mm}$ in diameter. Autozooecial apertures oval, arranged in regular diagonal rows. Autozooecial diaphragms locally present. Hemisepta absent. Metazooecia small, 12-20 of them arranged in three rows between apertures. Acanthostyles present, irregularly distributed between autozooecial apertures. Autozooecial walls laminated, 0.010$0.015 \mathrm{~mm}$ thick in endozone.

Remarks. Streblotrypa (Streblotrypa) parviformis n. sp. is similar to Streblotrypa (Streblotrypa) parva Morozova, 1965 from the Upper Permian of Caucasus, but differs from it by the presence of acanthostyles. Streblotrypa (Streblotrypa) parviformis differs from S. (S.) quadrata Liu, 1976 from the Lower Permian of China by the presence of acanthostyles and thinner branches (branch diameter $0.51-0.92 \mathrm{~mm}$ vs. $0.60-1.40 \mathrm{~mm}$ in $S$. (S.) quadrata). Streblotrypa (Streblotrypa) parviformis differs from S. (S.) elegans Sakagami, 1970 from the Lower Permian of Thailand by possessing acanthostyles and lacking hemisepta.

\section{Sub-genus STREBLOTRYPA (STREBLASCOPORA) Bassler, 1929}

Type species. Streblotrypa fasciculata Bassler, 1929. Upper Permian, Indonesia.

Diagnosis. Branched colonies. Clearly defined bundle of the axial zooecia in the endozone. Autozooecia budding from axial bundle, having long inflated proximal parts, rounded-polygonal in transverse section in the endozone, bending abruptly at the transition between endo- and exozone. Autozooecial apertures rounded to oval. Diaphragms rare. Inferior hemisepta commonly present, sometimes accompanied by superior hemisepta; in some species hemisepta absent. Metazooecia between the autozooecial apertures and beyond the distolateral margins of autozooecial apertures. Autozooecial walls laminated, without distinct autozooecial boundaries.

Remarks. Streblotrypa (Strebascopora) Bassler, 1929 differs from S. (Streblotrypa) Vine, 1885 by having a distinct axial bundle with more than 10 axial zooids.

Occurrence. Carboniferous to Permian; worldwide.

Streblotrypa (Streblascopora) delicatula Sakagami, 1961

Figure 13.4-8; Table 17

1961 Streblascopora delicatula Sakagami, p. 52, pl. 25 , figs. $7-10$, pl. 26 , fig. $2-18$, pl. 27 , figs. 1-5.

1973 Streblascopora delicatula Sakagami, 1961; Sakagami, p. 84-85, pl. 8, figs. 1-4.

1984 Streblascopora delicatula Sakagami, 1961; Yang and Lu, p. 53-54, pl. 1, fig. 5b, pl. 2, 3a, b.

1997 Streblascopora delicatula Sakagami, 1961; Sakagami and Pillevuit, p. 212, figs. 4-(9-11), 5-1. 
TABLE 17. Measurements of Streblotrypa (Streblascopora) delicatula Sakagami, 1961. Abbreviations as for Table 1.

\begin{tabular}{lcccccc}
\hline & $\mathbf{N}$ & $\mathbf{X}$ & SD & CV & MIN & MAX \\
\hline Branch width, mm & 4 & 1.68 & 0.288 & 17.14 & 1.30 & 2.00 \\
Axial bundle width, mm & 4 & 0.58 & 0.092 & 15.97 & 0.45 & 0.67 \\
Autozooecial aperture width, mm & 19 & 0.16 & 0.010 & 6.53 & 0.13 & 0.17 \\
Autozooecial aperture spacing along branch, mm & 15 & 0.45 & 0.055 & 12.15 & 0.37 & 0.55 \\
Autozooecial aperture spacing diagonally, mm & 15 & 0.29 & 0.034 & 11.50 & 0.24 & 0.35 \\
Metazooecia width, mm & 15 & 0.03 & 0.009 & 27.91 & 0.02 & 0.05 \\
Metazooecia per aperture & 7 & 7.4 & 0.976 & 13.14 & 6.0 & 9.0 \\
\hline
\end{tabular}

2008

Streblascopora delicatula Sakagami, 1961; Ernst, Weidlich and Schäfer, p. 692, figs. 9.1-9.2.

Material. SMF 23.143, SMF 23.205-SMF 23.208. Description. Branched colonies, 1.3-2.0 $\mathrm{mm}$ in diameter. Axial bundle $0.45-0.67 \mathrm{~mm}$ in diameter. Axial zooecia arranged in 6-8 rows. Autozooecia budding from the axial bundle, having long inflated proximal parts, rounded to polygonal in transverse section in the endozone. Autozooecial apertures oval, arranged in regular diagonal rows. Superior hemisepta weakly developed; inferior hemisepta long. Terminal diaphragms common. Metazooecia small, oval to rounded, 6-9 of them arranged in 23 rows between apertures. Autozooecial walls laminated, 0.005-0.010 mm thick in endozone.

Remarks. Streblotrypa (Streblascopora) delicatula Sakagami, 1961 differs from S. (S.) marmionensis (Etheridge, 1926) in having wider and less closely spaced autozooecial apertures (average aperture width $0.16 \mathrm{~mm}$ vs. $0.10 \mathrm{~mm}$ in S. [S.] marmionensis). Streblotrypa (Streblascopora) delicatula differs from S. (S.) germana Bassler, 1929 by the presence of hemisepta and wider autozooecial apertures (average aperture width $0.16 \mathrm{~mm}$ vs. 0.10 $\mathrm{mm}$ in S. [S.] germana).

Occurrence. Lower Permian; Japan, Thailand. Aseelah Unit, Saal Formation (Lower-?Middle Permian); Batain Coast (eastern Oman). Zhongba Formation, Permian (upper Cisuralian-Guadalupian); Zhongba area of southwestern Tibet.

\section{Streblotrypa (Streblascopora) marmionensis} (Etheridge, 1926)

Figures 13.9, 14.1-3; Table 18

1926 Streblotrypa marmionensis Etheridge in Bretnall, p. 22, pl. 1, fig. 1, pl. 2, fig. 3.

1931 Streblotrypa marmionensis Etheridge, 1926; Hosking, p. 14, pl. 6, fig. 1, text-fig. 1.

1944 Streblotrypa marmionensis Etheridge, 1926; Crockford, p. 168-169, pl. 5, figs. 10-11, textfigs. 34-37.
1957 Streblotrypa marmionensis Etheridge, 1926; Crockford, p. 80.

1966 ? Streblascopora cf. marmionensis (Etheridge, 1926); Sakagami, p. 166-167, pl. 6, fig. 11.

1983 Streblascopora cf. marmionensis (Etheridge, 1926); Yang and Lu, p. 291, pl. 2, fig. 6, pl. 4, figs. 8-9.

?1970 Streblascopora marmionensis (Etheridge, 1926); Morozova, p. 151-152, pl. 28, fig. 1.

1971 Streblascopora marmionensis (Etheridge, 1926); Termier and Termier, p. 24 (pars.), pl. 9, figs. 1-3, non 4-5.

1975 Streblascopora marmionensis (Etheridge, 1926); Gorjunova, p. 65, pl. 9, fig. 1.

1991 Streblascopora marmionensis (Etheridge, 1926); Xia, p. 184-185, pl. 5, figs. 7-10.

2008 Streblascopora marmionensis (Etheridge, 1926); Ernst, Weidlich and Schäfer, p. 694, figs. 8.10-8.11, 8.13.

2013 Streblascopora marmionensis (Etheridge, 1926); Ernst and Gorgij, p. 298, figs. 13d-h.

Material. SMF 23.144-SMF 23.151.

Description. Branched colonies, 1.00-1.55 mm in diameter, with $0.14-0.26 \mathrm{~mm}$ wide exozones and $0.65-1.15 \mathrm{~mm}$ wide endozones. Axial bundle $0.26-$ $0.54 \mathrm{~mm}$ in diameter. Axial zooecia arranged in 56 rows, $0.05-0.08 \mathrm{~mm}$ in diameter. Autozooecia budding from the axial bundle, having long inflated proximal parts, rounded to polygonal in transverse section in the endozone. Autozooecial apertures oval, arranged in regular diagonal rows. Inferior hemisepta present. Terminal diaphragms common. Metazooecia small, oval to rounded, 8-10 of them arranged in 2-3 rows between apertures. Autozooecial walls laminated, 0.005-0.010 mm thick in endozone.

Remarks. Streblotrypa (Streblascopora) marmionensis (Etheridge, 1926) differs from S. (S.) germana (Bassler, 1929) in possessing hemisepta, thicker branches and a larger diameter of the axial bundle. Streblotrypa (Streblascopora) marmionensis is similar to S. (S.) erecta Baranova, 1960a 

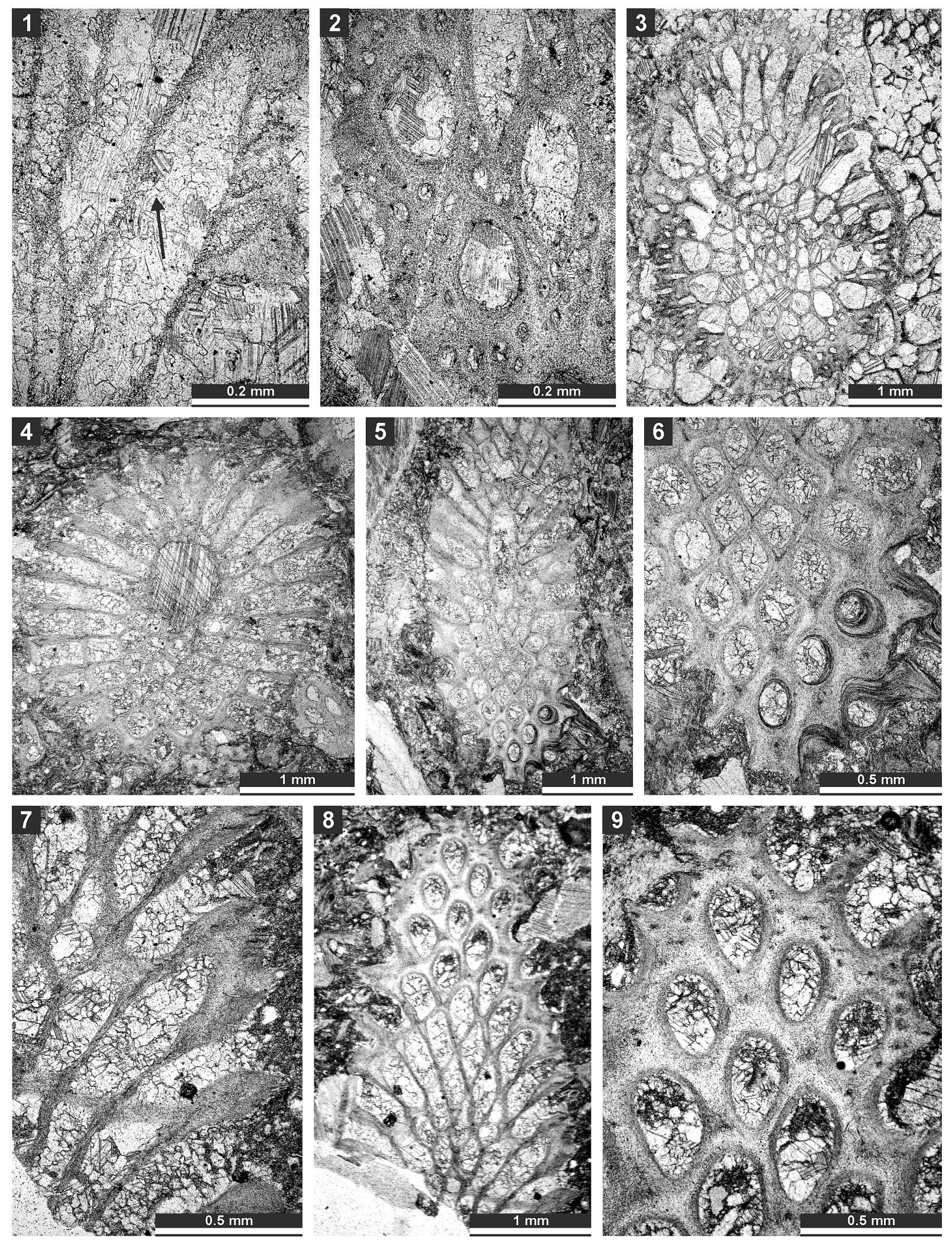

FIGURE 14. Thin section photographs of Streblotrypa (Streblascopora) marmionensis (Etheridge, 1926), SMF 23.145 (1 and 2), and SMF 23.148 (3); and Rhabdomeson bretnalli Crockford, 1957, SMF 23.155 (4-6) and SMF 23.157 (7-9). 1, longitudinal section; 2 and 7, tangential section; 3 and 4, branch transverse section; and 5, 6, 8 and 9 ; branch oblique section. 
TABLE 18. Measurements of Streblotrypa (Streblascopora) marmionensis (Etheridge, 1926). Abbreviations as for Table 1.

\begin{tabular}{lcccccc}
\hline & $\mathbf{N}$ & $\mathbf{X}$ & $\mathbf{S D}$ & $\mathbf{C V}$ & MIN & MAX \\
\hline Branch width, mm & 12 & 1.25 & 0.198 & 15.88 & 1.00 & 1.55 \\
Axial bundle width, mm & 12 & 0.38 & 0.077 & 20.26 & 0.26 & 0.54 \\
Exozone width, mm & 12 & 0.19 & 0.034 & 17.95 & 0.14 & 0.26 \\
Endozone width, mm & 12 & 0.87 & 0.165 & 18.88 & 0.65 & 1.15 \\
Autozooecial aperture width, mm & 12 & 0.11 & 0.010 & 9.22 & 0.10 & 0.13 \\
Metazooecia width, mm & 11 & 0.02 & 0.006 & 30.05 & 0.01 & 0.03 \\
\hline
\end{tabular}

TABLE 19. Measurements of Rhabdomeson bretnalli Crockford, 1957. Abbreviations as for Table 1.

\begin{tabular}{lcccccc}
\hline & N & X & SD & CV & MIN & MAX \\
\hline Branch width, mm & 7 & 2.45 & 0.610 & 24.91 & 1.60 & 3.30 \\
Axial tube diameter, mm & 7 & 0.53 & 0.158 & 29.76 & 0.27 & 0.80 \\
Autozooecial aperture width, mm & 18 & 0.17 & 0.021 & 12.58 & 0.12 & 0.20 \\
Autozooecial aperture spacing along branch, mm & 10 & 0.41 & 0.068 & 16.60 & 0.36 & 0.56 \\
Autozooecial aperture spacing diagonally, mm & 12 & 0.27 & 0.028 & 10.44 & 0.22 & 0.31 \\
\hline
\end{tabular}

from the Lower Permian of northeastern Russia, but differs from it by more metazooecia between autozooecial apertures (8-10 vs. 6-9). Streblotrypa (Streblascopora) marmionensis differs from S. (S.) tscharlakensis Trizna, 1950 from the Lower Permian (Sakmarian-Artinskian) of Urals in having a larger number of axial zooecia in the axial bundle and a larger number of metazooecia between autozooecial apertures (8-10 vs. $6-8$ ).

Occurrence. Lower Permian (Noonkanbah Series and Liveringa Formation); Western Australia. Lower Permian; Pamir, Tajikistan. Aseelah Unit, Saal Formation (Lower-?Middle Permian); Batain Coast (eastern Oman). Chili Formation, Lower Permian (Sakmarian-Artinskian); Kalmard area, central Iran. Zhongba Formation, Permian (upper Cisuralian-Guadalupian); Zhongba area of southwestern Tibet.

Family RHABDOMESIDAE Vine, 1884

Genus RHABDOMESON Young and Young, 1874 [= Coeloconus Ulrich, 1889]

Type species. Rhabdomeson progracile Wyse Jackson and Bancroft, 1995 (ICZN Opinion 1874). Lower Carboniferous; Ireland.

Diagnosis. Rhabdomesid with delicate dendroid colony with irregularly dichotomizing branches. Autozooecia regularly budding around central axial cylinder in an annual or spiral manner. Hemisepta common. Autozooecial apertures elliptical, pyriform or rhombic, closely spaced, arranged in quincunx on colony surface; of constant or variable dimensions around branch. Stylets abundant and struc- turally diverse (modified after Wyse Jackson and Bancroft, 1995).

Remarks. Rhabdomeson differs from other rhadbomesines in the presence of a central axial cylinder. Rhabdomeson differs from Silenella Gorjunova, 1992 in the absence of aktinotostyles and from Pseudorhabdomeson Gorjunova, 2002 in having a rounded axial tube instead of a polygonal one as well as the presence of differentiated styles instead of aktinotostyles.

Occurrence. Middle Devonian to Upper Permian; worldwide.

\section{Rhabdomeson bretnalli Crockford, 1957}

Figure 14.4-9; Table 19

1957

Rhabdomeson bretnalli Crockford, p. 75, pl. 20, figs. 4-7.

Material. SMF 23.152-SMF 23.157.

Description. Branched colonies with small axial cylinder. Branches 1.6-3.3 mm in diameter. Axial cylinder circular, $0.27-0.80 \mathrm{~mm}$ in diameter. Autozooecia budding in a spiral pattern from the axial cylinder, rhomboid in transverse section. Autozooecial apertures oval, arranged in regular diagonal rows. Single macroacanthostyle between each aperture present building a regular rhombic pattern, $0.03-0.07 \mathrm{~mm}$ in diameter. Microacanthostyles abundant, arranged in 1-2 rows between macroacanthostyles, $0.02-0.03 \mathrm{~mm}$ in diameter. Hemisepta absent. Diaphragms rare. Autozooecial walls laminated, $0.010-0.015 \mathrm{~mm}$ thick in endozone.

Remarks. Rhabdomeson bretnalli Crockford, 1957 is similar to Rhabdomeson xinjiangense Yang and 

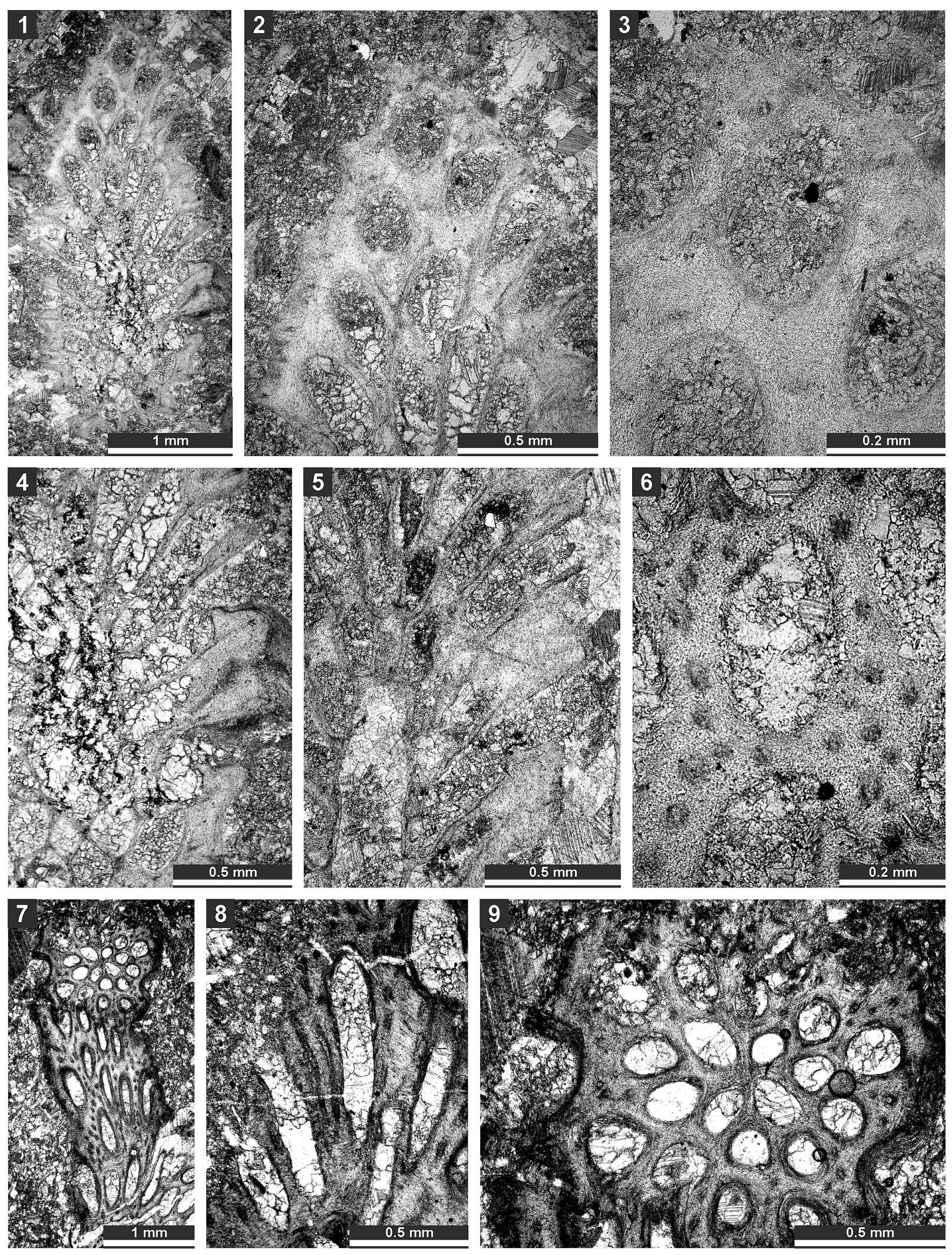

FIGURE 15. Thin section photographs of Rhabdomeson sp. SMF 23.160 (1-4) and SMF 23.158 (5); and Primorella rotunda Gorjunova, 1985, SMF 23.163 (6) and SMF 23.162 (7-9). 1-3, branch oblique section; 4 and 5, longitudinal section; 6, tangential section; and 7-9, oblique section. 
TABLE 20. Measurements of Primorella rotunda Gorjunova, 1975. Abbreviations as for Table 1.

\begin{tabular}{lcccccc}
\hline & $\mathbf{N}$ & $\mathbf{X}$ & $\mathbf{S D}$ & $\mathbf{C V}$ & MIN & MAX \\
\hline Autozooecial aperture width, $\mathrm{mm}$ & 30 & 0.17 & 0.026 & 15.98 & 0.12 & 0.22 \\
Autozooecial aperture spacing along branch, $\mathrm{mm}$ & 5 & 0.53 & 0.050 & 9.33 & 0.48 & 0.61 \\
Autozooecial aperture spacing diagonally, $\mathrm{mm}$ & 5 & 0.36 & 0.050 & 14.02 & 0.32 & 0.44 \\
Aktinotostyle diameter, mm & 20 & 0.027 & 0.007 & 25.38 & 0.010 & 0.038 \\
\hline
\end{tabular}

Lu, 1983 from the Baliqliq Group of western Xinjiang, China, but differs from it by the regular presence of four macroacanthostyles surrounding autozooecial apertures instead of 7-10 acanthostyles in the latter species. Rhabdomeson bretnalli differs from $R$. ofukuensis Sakagami, 1964 from the Permian of Japan in having larger autozooecial apertures (average aperture width $0.17 \mathrm{~mm}$ vs. $0.13 \mathrm{~mm}$ in $R$. ofukuensis).

Occurrence. Lower Permian (Noonkanbah Series and Liveringa Formation); Western Australia. Zhongba Formation, Permian (upper CisuralianGuadalupian); Zhongba area of southwestern Tibet.

\section{Rhabdomeson sp.}

Figure 15.1-5

Material. SMF 23.158-SMF 23.160.

Description. Branched colonies with small axial cylinder. Branches 1.48-1.53 $\mathrm{mm}$ in diameter. Axial cylinder circular, $0.26-0.34 \mathrm{~mm}$ in diameter. Autozooecia budding in a spiral pattern from the axial cylinder, rhomboid in transverse section. Autozooecial apertures oval, arranged in regular diagonal rows, $0.15-0.19 \mathrm{~mm}$ wide. Two macroacanthostyles between each aperture present, 0.05$0.08 \mathrm{~mm}$ in diameter. Microacanthostyles abundant, arranged in one row between macroacanthostyles, $0.015-0.020 \mathrm{~mm}$ in diameter. Superior hemisepta present, curved proximally. Diaphragms absent. Autozooecial walls laminated, 0.010-0.015 $\mathrm{mm}$ thick in endozone.

Remarks. Rhabdomeson $\mathrm{sp}$. is similar to R. bispinosum Crockford, 1944 from the Lower Permian (Artinskian) of Western Australia, but differs in the presence of hemisepta and by having wider autozooecial apertures (aperture width $0.15-0.19 \mathrm{~mm}$ vs. $0.08-0.10 \mathrm{~mm}$ in $R$. bispinosum). Rhabdomeson sp. differs from $R$. consimile Bassler, 1929 from the Upper Permian of Timor, by having wider apertures (aperture width $0.15-0.19 \mathrm{~mm}$ vs. ca $0.12 \mathrm{~mm}$ in $R$. consimile).

Occurrence. Zhongba Formation, Permian (upper Cisuralian-Guadalupian); Zhongba area of southwestern Tibet.
Family RHOMBOPORIDAE Simpson, 1895 Genus PRIMORELLA Romantchuk and Kiseleva, 1968

Type species. Primorella polita Romantchuk and Kiseleva, 1968. Upper Permian, Primorje, East Russia.

Diagnosis. Branched colonies with long and tubelike autozooecia budding in spiral pattern. Oval apertures arranged in regular diagonal rows. Abundant aktinotostyles in walls of the exozone (modified after Gorjunova, 1985).

Remarks. Primorella differs from other genera of the family Rhomboporidae by the presence of aktinotostyles. Primorella differs from Pamirella Gorjunova, 1975 by the absence of acanthostyles.

Occurrence. Carboniferous and Permian of the Russian Plate, Mongolia, Iran, and Arctic.

\section{Primorella rotunda Gorjunova, 1985}

Figure 15.6-9; Table 20

1985 Primorella rotunda Gorjunova, p. 92, pl. 11, figs. 2-3.

2008 Primorella cf. rotunda Gorjunova, 1985; Ernst, Weidlich and Schäfer, p. 704, figs. 11.10-11.14.

2013 Primorella rotunda Gorjunova, 1985; Ernst and Gorgij, p. 298, figs. 14A-E.

Material. SMF 23.161-SMF 23.164.

Description. Branched colonies, $1.4-1.6 \mathrm{~mm}$ in diameter. Autozooecia growing from median axis. Apertures oval. Aktinotostyles abundant, arranged in a single row around apertures. Autozooecial diaphragms and heteromorphs not observed. Walls laminated, $0.010-0.015 \mathrm{~mm}$ thick in endozone, 0.07-0.09 mm thick in exozone.

Remarks. Primorella rotunda Gorjunova, 1985 differs from $P$. opulenta Gorjunova, 1985 from the Lower Permian (Sakmarian) of Russia, in having thicker branches (branch diameter 1.4-1.6 mm vs. $0.7-0.8 \mathrm{~mm}$ in $P$. opulenta) and wider autozooecial apertures (aperture width $0.12-0.22 \mathrm{~mm}$ vs. $0.11-$ $0.13 \mathrm{~mm}$ in P. opulenta). Primorella rotunda differs from $P$. serena Gorjunova, 1975 from the Lower Permian (Sakmarian) of Tajikistan in having thinner colonies (branch diameter 1.4-1.6 mm vs. 2.15$2.30 \mathrm{~mm}$ in $P$. serena) and wider autozooecial 
apertures (aperture width $0.12-0.22 \mathrm{~mm}$ vs. $0.12-$ $0.14 \mathrm{~mm}$ in $P$. serena).

Occurrence. Lower Permian (Artinskian); Pamir (Tajikistan). Chili Formation, Lower Permian (Sakmarian-Artinskian); Kalmard area, central Iran. Aseelah Unit, Saal Formation (?Lower Permian); Batain Coast (eastern Oman). Zhongba Formation, Permian (upper Cisuralian-Guadalupian); Zhongba area of southwestern Tibet.

Suborder TIMANODICTYINA Morozova, 1966

Family TIMANODICTYIDAE Morozova, 1966

Genus TIMANOTRYPA Nikiforova, 1938

Type species. Timanotrypa foliata Nikiforova, 1938. Lower Permian, Sakmarian; Russia.

Diagnosis. Bifoliate, frondose, leaf-shaped colonies. Branched colonies; branches bifoliate, lenticular, rounded or oval in transverse section. Autozooecia tubular, widened proximally and bending at low angles in exozone. Mesotheca straight or zigzag folded. Median tubules absent. Autozooecial diaphragms rare. Exozonal walls laminated, traversed by abundant microstyles. Maculae lacking autozooecia present. Heterozooecia absent.

Remarks. Timanotrypa Nikiforova, 1938 differs from Timanodictya Nikiforova, 1938 in having frondose or leaf-shaped colonies instead of branched ones.

Occurrence. Lower Permian of Arctic, Tibet and Australia, Upper Permian (Kazanian) of the Russian Plate.

Timanotrypa australis $\mathrm{n} . \mathrm{sp}$.

Figure 16; Table 21

zoobank.org/7E383F60-0575-4490-888B-3A8CF8F4500D

1973 Timanodictya? sp. Sakagami, p. 85, pl. 14, fig. 3.

Etymology. The species is named after its occurrence in southern hemisphere (from Latin "australis" southern).

Holotype. SMF 23.165.

Paratypes. SMF 23.166-SMF 23.177.

Type locality. Zhongba area of southwestern Tibet (E 84.31536, N 29.74233).

Type stratum. Zhongba Formation, Permian (upper Cisuralian-Guadalupian).

Diagnosis. Colonies consisting of narrow bifoliate ribbons growing in the same plane, apparently pinnate; mesotheca straight to slightly zigzag folded; autozooecia tubular, semicircular in endozone, recumbent at mesotheca, bending sharply in exozone; diaphragms and hemisepta absent; exozonal walls laminated, traversed by abundant microstyles; depressed maculae without autozooecia occurring between pinnae.
Description. Colonies consisting of narrow bifoliate ribbons growing in the same plane, apparently pinnate (complete colony shape unknown). Separate ribbons $3.2-6.7 \mathrm{~mm}$ wide and $1.1-2.2 \mathrm{~mm}$ thick, with $0.26-0.65 \mathrm{~mm}$ wide exozone and $0.58-$ $0.90 \mathrm{~mm}$ wide endozones. Mesotheca straight to slightly zigzag folded, $0.025-0.038 \mathrm{~mm}$ thick. Autozooecia tubular, semicircular in endozone, recumbent at mesotheca, bending sharply in exozone. Autozooecial apertures rounded to oval, arranged in 8-15 alternating rows. Autozooecial diaphragms not observed. Hemisepta absent. Endozonal walls hyaline, $0.015-0.020 \mathrm{~mm}$ thick. Exozonal walls laminated, traversed by abundant microstyles. Microstyles $0.015-0.025 \mathrm{~mm}$ in diameter. Maculae depressed, narrow, lacking autozooecia, positioned between pinnae across branch axis. Elliptical nodes regularly spaced between autozooecial apertures, 0.06-0.10 $\mathrm{mm}$ in diameter.

Remarks. Timanodictya? sp. Sakagami, 1973 (p. 85 , plate 14 , figure 3 ) fits with the new species (average aperture width 0.16 (range 0.14-0.18 $\mathrm{mm}$ ) vs. 0.16 (range $0.13-0.19 \mathrm{~mm}$ ) in the present species). Timanotrypa australis $\mathrm{n}$. $\mathrm{sp}$. differs from T. borealis Morozova, 1970 from the Upper Permian (Kazanian) of the Russian Platform, by possessing smaller fronds (frond width 3.2-6.7 $\mathrm{mm}$ vs. 6-9 mm in T. borealis; frond thickness $1.1-2.2 \mathrm{~mm}$ vs. $2.0-3.0 \mathrm{~mm}$ in $T$. borealis).

The wall structure in timanodictyid bryozoans is quite variable and includes such structures as microstyles and stenostyles. The term "stenostyle" has been suggested by Gilmour and Snyder (1986) instead of "cappilares" used by the Russian authors (cf. Morozova, 1970; Gorjunova, 1994). However, these structures are not uniform in their morphology among timanodctyines. Gilmour (personal commun., 2015) understands rods of stellate appearance in transverse section as stenostyles, whereas others are of circular shape in their transverse sections (as known in the Family Girtyporidae, for example). The original diagnosis of the genus Timanotrypa Nikiforova (1938) includes "stellate acanthostyles". However, her figures 5-6 of plate 50 and figures 1-4 of plate 52 do not reveal any of such styles. Instead, they show small styles of circular shape in their transverse section. Neither the sample of Timanotrypa depicted by Gorunova (1994, plate 3, figure 1) shows any kind of stellate styles. The assignment of the present material to Timanotrypa followed largely on the base of the autozooecial shape, which is a very important character in the bryozoan morphology. 

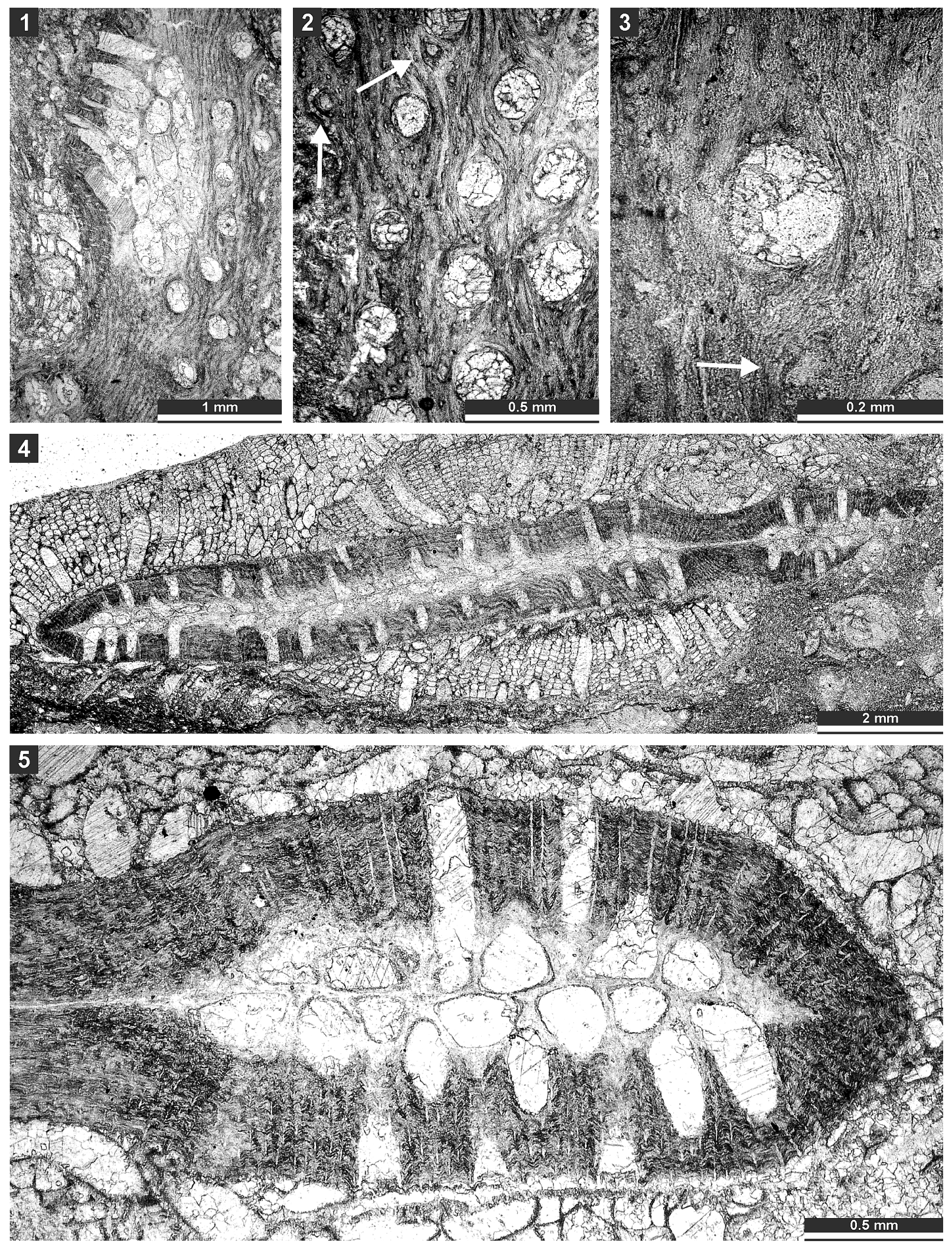

FIGURE 16. Thin section photographs of Timanotrypa australis n. sp., holotype SMF 23.165 (1), paratype SMF 23.166 (2 and 3), paratype SMF 23.169 (4), and paratype SMF 23.171 (5). 1, oblique section of the pinnate branch; 2 and 3 , tangential section showing autozooecial apertures, nodes (arrows) and microstyles; and 4 and 5, branch transverse section. 
TABLE 21. Measurements of Timanotrypa australis n. sp. Abbreviations as for Table 1.

\begin{tabular}{lcccccc}
\hline & $\mathbf{N}$ & $\mathbf{X}$ & $\mathbf{S D}$ & $\mathbf{C V}$ & MIN & MAX \\
\hline Branch width, mm & 4 & 4.9 & 1.458 & 29.76 & 3.2 & 6.7 \\
Branch thickness, mm & 5 & 1.7 & 0.415 & 24.69 & 1.1 & 2.2 \\
Autozooecial aperture width, mm & 35 & 0.16 & 0.012 & 7.60 & 0.13 & 0.19 \\
Autozooecial aperture spacing along branch, mm & 8 & 0.79 & 0.044 & 5.55 & 0.72 & 0.85 \\
Autozooecial aperture spacing diagonally, mm & 30 & 0.44 & 0.051 & 11.57 & 0.37 & 0.55 \\
Node diameter, mm & 5 & 0.08 & 0.015 & 18.05 & 0.06 & 0.10
\end{tabular}

Occurrence. Rat Buri Limestone, Lower Permian (?Artinskian-Kungurian); Khao Raen, Thailand. Noonkanbah Formation, Lower Permian (upper Artinskian-Kungurian); Western Australia (unpublished data). Zhongba Formation, Permian (upper Cisuralian-Guadalupian); Zhongba area of southwestern Tibet.

Order FENESTRATA Elias and Condra, 1957 Suborder FENESTELLINA Astrova and Morozova, 1956

Family FENESTELLIDAE King, 1849

Genus SPINOFENESTELLA Termier and Termier, 1971

[= Alternifenestella Termier and Termier, 1971]

Type species. Fenestella spinosa Condra, 1902. Lower Permian (Wolfcampian); North America.

Diagnosis. Reticulate colonies with relatively wide and thick branches and relatively thin dissepiments. Autozooecia arranged in two rows on the branches. Autozooecia triangular in mid-tangential section, triangular to pentagonal proximal to bifurcations. Narrow keel with single row of nodes developed.

Remarks. Spinofenestella Termier and Termier, 1971 differs from the genus Rectifenestella Morozova, 1974 by the triangular shape of the autozooecia in mid-tangential section.

Alternifenestella Termier and Termier, 1971 is a synonym of Spinofenestella due to the close morphological similarities of their type species, according to Hageman and McKinney (2010), though Gorjunova and Weis (2012) retained Alternifenestella as a valid genus.

Occurrence. Lower Devonian-Upper Permian.

Spinofenestella sp.

Figure 17.1-5; Table 22

Material. SMF 23.178.

Exterior description. Reticulate colony formed by straight branches joined by wide dissepiments. Fenestrules oval to rectangular, short, narrow. Autozooecia arranged in two rows on branches.
Autozooecial apertures circular, with stellate structure; two apertures spaced per fenestrule length. Median keel low, narrow, containing small closely spaced rounded nodes. Large nodes on the reverse side of branches.

Interior description. Autozooecia short, triangular to trapezoid in mid-tangential section; with short to moderately long vestibule in longitudinal section. Axial wall between autozooecial rows strongly zigzag; aperture positioned at distal end of chamber. Superior hemisepta weakly developed; inferior hemisepta absent. External laminated skeleton well-developed on both obverse and reverse sides, traversed by small microstyles. Heteromorphs not observed.

Remarks. Spinofenestella $\mathrm{sp}$. is similar to $S$. cibaria (Trizna, 1950) from the Lower Permian of Russia, but differs from it in presence of nodes on the reverse colony side and wider branches $(0.28-$ $0.34 \mathrm{~mm}$ vs. $0.20-0.30 \mathrm{~mm}$ in $S$. cibaria). Spinofenestella sp. differs from S. microaperturata (Schulga-Nesterenko, 1941) from the Lower Permian of Russia in the presence of nodes on the reverse colony side and wider branches $(0.38-0.34$ $\mathrm{mm}$ vs. $0.20-0.30 \mathrm{~mm}$ in S. microaperturata).

Minilya magnispinata (Schulga-Nesterenko, 1952), from the Lower Permian of Urals, has similar colony dimensions and similar kinds of nodes on the reverse colony side. However, the latter species has alternating nodes on the keel (characteristic of the genus Minilya) and narrower branches (branch width $0.22-0.25 \mathrm{~mm}$ vs. $0.28-$ $0.34 \mathrm{~mm}$ in the present species).

Occurrence. Zhongba Formation, Permian (upper Cisuralian-Guadalupian); Zhongba area of southwestern Tibet.

\section{Spinofenestella subquadratopora (Schulga- Nesterenko, 1952) \\ Figure 17.6-8; Table 23}

1952 Fenestella subquadratopora Schulga-Nesterenko, 1952, p. 47 , pl. 9, fig. 5. 

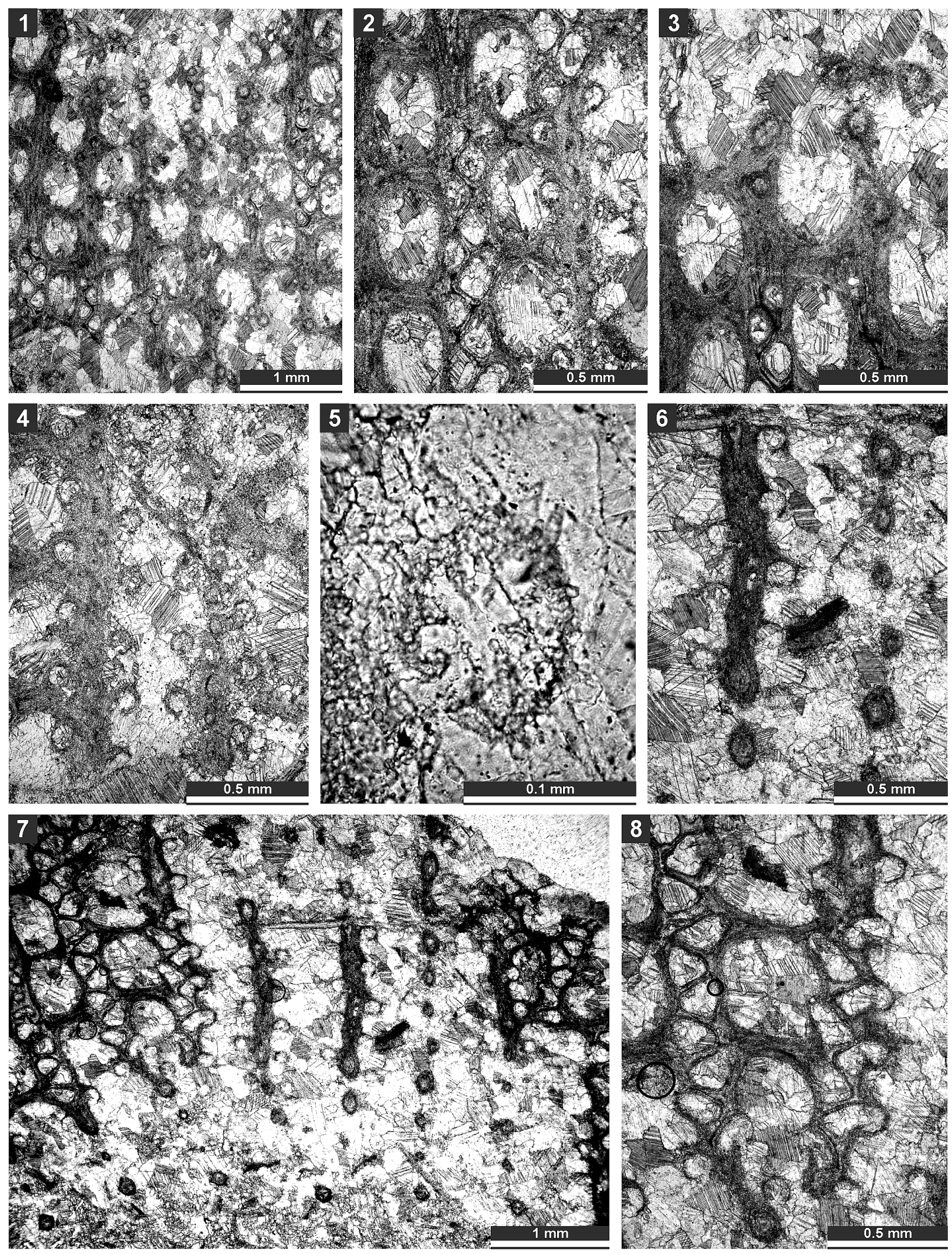

FIGURE 17. Thin section photographs of Spinofenestella sp., SMF 23.178 (1-5); and Spinofenestella subquadratopora (Schulga-Nesterenko, 1952), SMF 23. 179 (6-8). 1-3, tangential section of the reverse side; 4-7, tangential section of the obverse side; and 8 , mid- tangential section. 
TABLE 22. Measurements of Spinofenestella sp. Abbreviations as for Table 1.

\begin{tabular}{lcccccc}
\hline & $\mathbf{N}$ & $\mathbf{X}$ & SD & $\mathbf{C V}$ & MIN & MAX \\
\hline Branch width, mm & 15 & 0.30 & 0.020 & 6.67 & 0.28 & 0.34 \\
Dissepiment width, mm & 15 & 0.15 & 0.009 & 6.05 & 0.14 & 0.17 \\
Fenestrule width, mm & 15 & 0.23 & 0.019 & 8.01 & 0.20 & 0.27 \\
Fenestrule length, mm & 15 & 0.41 & 0.018 & 4.26 & 0.38 & 0.45 \\
Distance between branch centres, mm & 15 & 0.51 & 0.032 & 6.27 & 0.45 & 0.56 \\
Distance between dissepiment centres, mm & 15 & 0.56 & 0.025 & 4.38 & 0.52 & 0.61 \\
Autozooecial aperture width, mm & 20 & 0.07 & 0.007 & 9.13 & 0.06 & 0.09 \\
Autozooecial aperture spacing along branch, mm & 20 & 0.26 & 0.015 & 5.72 & 0.24 & 0.29 \\
Autozooecial aperture spacing diagonally, mm & 20 & 0.30 & 0.014 & 4.51 & 0.27 & 0.33 \\
Maximum chamber width, mm & 20 & 0.12 & 0.008 & 6.62 & 0.11 & 0.14 \\
Keel node diameter, mm & 15 & 0.06 & 0.008 & 12.94 & 0.05 & 0.08 \\
Node spacing, mm & 15 & 0.13 & 0.011 & 8.35 & 0.10 & 0.14 \\
Node diameter, reverse side, mm & 20 & 0.11 & 0.020 & 18.01 & 0.08 & 0.15 \\
\hline
\end{tabular}

TABLE 23. Measurements of Spinofenestella subquadratopora (Schulga-Nesterenko, 1952). Abbreviations as for Table 1.

\begin{tabular}{|c|c|c|c|c|c|c|}
\hline & $\mathbf{N}$ & $\mathbf{X}$ & SD & $\mathrm{CV}$ & MIN & MAX \\
\hline Branch width, mm & 10 & 0.32 & 0.023 & 7.16 & 0.29 & 0.36 \\
\hline Dissepiment width, $\mathrm{mm}$ & 10 & 0.12 & 0.022 & 18.00 & 0.10 & 0.17 \\
\hline Fenestrule width, $\mathrm{mm}$ & 10 & 0.33 & 0.047 & 14.42 & 0.25 & 0.39 \\
\hline Fenestrule length, $\mathrm{mm}$ & 10 & 0.46 & 0.036 & 7.82 & 0.40 & 0.50 \\
\hline Distance between branch centres, $\mathrm{mm}$ & 10 & 0.62 & 0.094 & 15.21 & 0.48 & 0.80 \\
\hline Distance between dissepiment centres, $\mathrm{mm}$ & 10 & 0.59 & 0.041 & 7.03 & 0.53 & 0.68 \\
\hline Autozooecial aperture width, $\mathrm{mm}$ & 10 & 0.10 & 0.007 & 7.45 & 0.09 & 0.11 \\
\hline Autozooecial aperture spacing along branch, $\mathrm{mm}$ & 10 & 0.29 & 0.018 & 6.03 & 0.27 & 0.32 \\
\hline Autozooecial aperture spacing diagonally, mm & 10 & 0.31 & 0.023 & 7.50 & 0.28 & 0.35 \\
\hline Maximum chamber width, $\mathrm{mm}$ & 10 & 0.17 & 0.018 & 10.70 & 0.14 & 0.19 \\
\hline Keel node diameter, $\mathrm{mm}$ & 20 & 0.11 & 0.017 & 15.88 & 0.08 & 0.14 \\
\hline Node spacing, mm & 20 & 0.30 & 0.021 & 7.03 & 0.25 & 0.34 \\
\hline
\end{tabular}

1975 Fenestella subquadratopora Schulga-Nesterenko, 1952; Gorjunova, p. 84, pl. 19, fig. 3, pl. 20, fig. 1.

1994 Alternifenestella subquadratopora SchulgaNesterenko, 1952; Nakrem, p. 94, fig. 17AB.

2000 Alternifenestella subquadratopora SchulgaNesterenko, 1952; Ernst, p. 97, pl. 21, figs. 3-5.

Material. SMF 23.179-SMF 23.181.

Exterior description. Reticulate colony formed by straight branches joined by wide dissepiments. Fenestrules oval to rectangular, long, narrow. Autozooecia arranged in two rows on branches. Autozooecial apertures circular, with low smooth peristome; two apertures spaced per fenestrule length. Median keel low, relatively wide, containing large widely spaced elliptical nodes.
Interior description. Autozooecia short, triangular in mid-tangential section; with short to moderately long vestibule in longitudinal section. Axial wall between autozooecial rows strongly zigzag; aperture positioned at distal end of chamber. Superior hemisepta long; inferior hemisepta absent. External laminated skeleton well-developed on both obverse and reverse sides, traversed by small microstyles. Microstyles $0.010-0.015 \mathrm{~mm}$ in diameter. Heteromorphs not observed. Nodes on the reverse side irregularly distributed, 0.035-0.051 $\mathrm{mm}$ in diameter.

Remarks. Spinofenestella subquadratopora (Schulga-Nesterenko, 1952) is similar to Spinofenestella macronodata (Sakagami, 1964) from the Lower Permian of Japan, but differs from it in having wider branches (branch width 0.29-0.36 $\mathrm{mm}$ vs. $0.21-0.24 \mathrm{~mm}$ in $S$. macronodata) and 
larger fenestrules (average fenestrule width 0.33 $\mathrm{mm}$ vs. $0.28 \mathrm{~mm}$ in $S$. macronodata; average fenestrule length $0.46 \mathrm{~mm}$ vs. $0.40 \mathrm{~mm}$ in S. macronodata). Spinofenestella subquadratopora differs from S. pulcherrima (Schulga-Nesterenko, 1941) from the Lower Permian of Russia by having larger nodes on the keel (node diameter 0.08-0.14 mm vs. $0.03-0.06$ in S. pulcherrima) and an irregular distribution of nodes on the reverse side of the colony; the nodes in S. pulcherrima are arranged in regular rows.

Occurrence. Upper Carboniferous, late Gzhelian, lowermost part of the Tyrrelfjellet Member; Spitsbergen. Lower Permian (Sakmarian); Urals, Russia. Trogkofel Formation, Lower Permian (late Sakmarian-late Artinskian); Carnic Alps, Austria. Zhongba Formation, Permian (upper CisuralianGuadalupian); Zhongba area of southwestern Tibet.

Family POLYPORIDAE Vine, 1884 Genus POLYPORA M'Coy, 1844

Type species. Polypora dendroides M'Coy, 1844. Lower Carboniferous; Ireland.

Diagnosis. Reticulate colonies of different shape built by straight or slightly undulating, bifurcating branches, joined at regular intervals by straight dissepiments without autozooecia. Autozooecia arranged in four alternating rows on branches, 5-6 rows before and 2-3 after bifurcation. Autozooecial chambers tubular, short, having weakly developed inferior hemisepta and short vestibule, regularly hexagonal in mid tangential section. Autozooecial apertures rounded. Keels between longitudinal rows of autozooecia weakly developed or absent. Microacanthostyles and nodes usually present on obverse surface (after Morozova, 2001).

Remarks. Polypora M'Coy, 1844 is similar to Paucipora Termier and Termier, 1971. The latter has well-developed hemisepta and shorter autozooecia. Polypora differs from Polyporella Simpson, 1895 in the presence of four rows of autozooecia on branches instead of three in the latter genus.

Occurrence. Lower Devonian to Upper Permian; worldwide.

Polypora consanguinea Bassler, 1929

Figure 18.1-4; Table 24

1929 Polypora consanguinea Bassler, p. 79, pl. 19 , figs. 5-9.

Material. SMF 23.182.

Exterior description. Reticulate colonies composed of moderately wide branches jointed by moderately wide dissepiments. Autozooecia arranged in 4-5 alternating rows on branches.
Autozooecial apertures rounded to oval, 4-10 spaced per length of fenestrule. Fenestrules long, oval, narrow. Node regularly spaced between subsequent autozooecial apertures, $0.03-0.04 \mathrm{~mm}$ in diameter. Reverse colony surface smooth.

Interior description. Autozooecial chambers moderately long, generally rhombic to roughly hexagonal in the mid tangential section. Hemisepta absent. External laminated skeleton well-developed, traversed by abundant small microacanthostyles. Heteromorphs not observed.

Remarks. Polypora consanguinea Bassler, 1929 is similar to $P$. russiensis Schulga-Nesterenko 1941 from the Lower Permian of Russia, but differs from it in having wider branches (branch width 1.08$1.45 \mathrm{~mm}$ vs. $0.52-0.88 \mathrm{~mm}$ in $P$. russiensis) and wider fenestrules (fenestrule width 1.08-1.40 mm vs. $0.45-0.70 \mathrm{~mm}$ in $P$. russiensis). Polypora consanguinea differs from $P$. multiporifera Crockford, 1944 from the Lower Permian of Western Australia in having wider branches (branch width 1.08-1.45 $\mathrm{mm}$ vs. $0.70-1.10$ in $P$. multiporifera) as well as wider and shorter fenestrules (fenestrule width $1.08-1.40 \mathrm{~mm}$ vs. $0.65-1.10 \mathrm{~mm}$ in P. multiporifera; fenestrule length $2.00-2.10 \mathrm{~mm}$ vs. $2.1-2.45$ $\mathrm{mm}$ in $P$. multiporifera). Polypora consanguinea Bassler, 1929 has been reported from the Lower Permian (Kungurian) of northern Russia (Morozova, 1981, p. 85), however, this species possesses hemisepta.

Occurrence. Permian (Sakmarian-Artinskian); Indonesia, Timor. Zhongba Formation, Permian (upper Cisuralian-Guadalupian); Zhongba area of southwestern Tibet.

\section{Polypora brouweri Bassler, 1929 Figure 18.5-9; Table 25}

1929

Polypora brouweri Bassler, p. 77, pl. 18, figs. 7-10.

1946 Polypora goldfussi Eichwald, 1860; Metz, p. 181, pl. 19, fig. 9.

Material. SMF 23.183.

Exterior description. Reticulate colonies composed of moderately wide branches jointed by moderately wide dissepiments. Autozooecia arranged in 4-5 alternating rows on branches. Autozooecial apertures rounded to oval, 4-10 spaced per length of fenestrule. Fenestrules long, oval to rectangular. Keels and nodes absent. Reverse colony surface smooth.

Interior description. Autozooecial chambers moderately long, generally rhombic to roughly hexagonal, irregularly polygonal at places of bifurcation in the mid-tangential section. Hemisepta absent. External laminated skeleton well-developed, tra- 

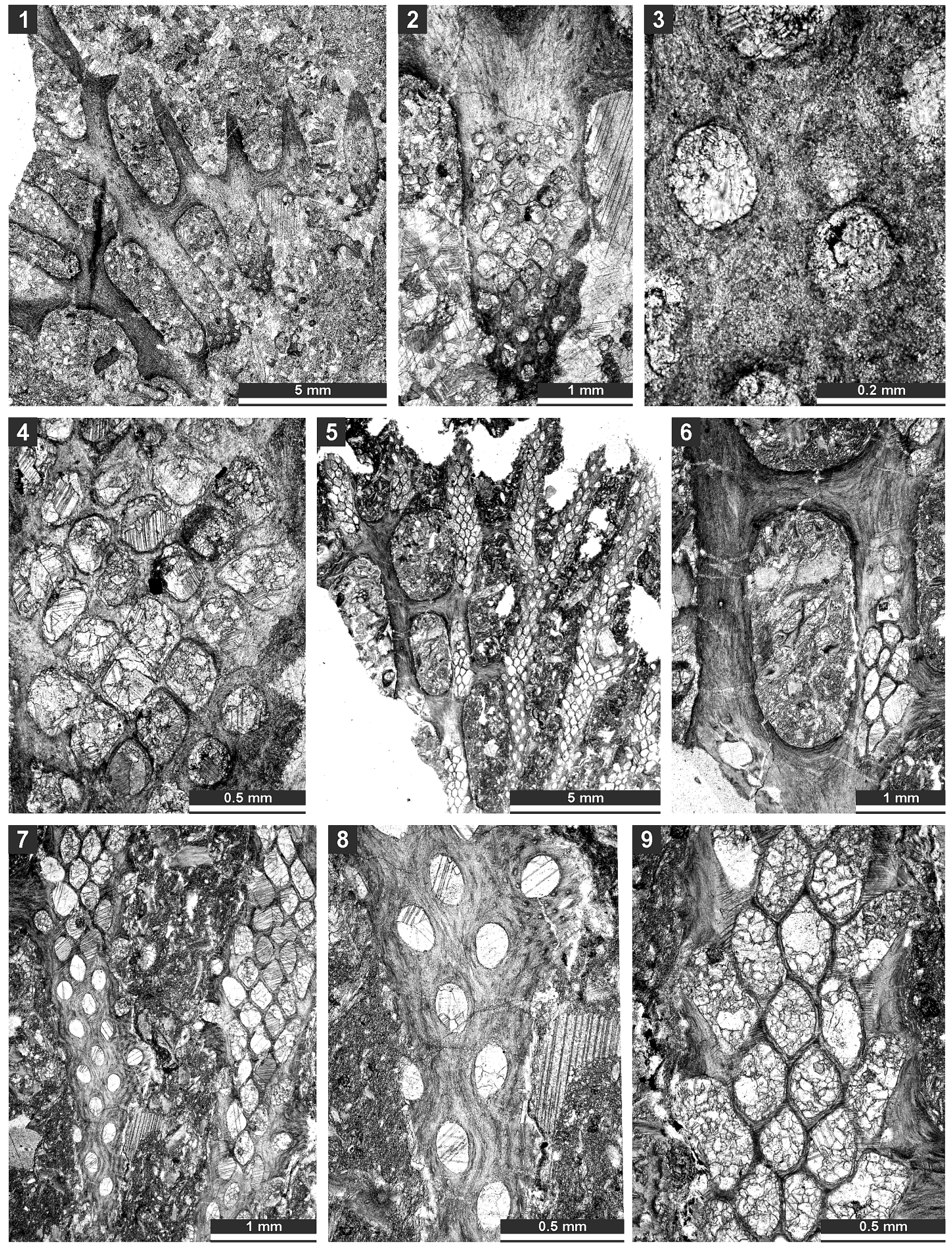

FIGURE 18. Thin section photographs of Polypora consanguinea Bassler, 1929, SMF 23.182 (1-4); and Polypora brouweri Bassler, 1929, SMF 23.183 (5-9). 1, oblique section; 2-5, tangential section showing autozooecial apertures, nodes and autozooecial chambers; 6 , reverse side of the colony; and 7-9, tangential section showing autozooecial apertures and chambers. 
TABLE 24. Measurements of Polypora consanguinea Bassler, 1929. Abbreviations as for Table 1.

\begin{tabular}{lcccccc}
\hline & $\mathbf{N}$ & $\mathbf{X}$ & $\mathbf{S D}$ & $\mathbf{C V}$ & MIN & MAX \\
\hline Branch width, mm & 5 & 1.27 & 0.180 & 14.21 & 1.08 & 1.45 \\
Dissepiment width, mm & 2 & 0.54 & 0.014 & 2.62 & 0.53 & 0.55 \\
Fenestrule width, mm & 4 & 1.24 & 0.159 & 12.79 & 1.08 & 1.40 \\
Fenestrule length, mm & 2 & 2.05 & 0.071 & 3.45 & 2.00 & 2.10 \\
Autozooecial aperture width, mm & 9 & 0.13 & 0.005 & 4.20 & 0.12 & 0.13 \\
Autozooecial aperture spacing along branch, mm & 7 & 0.41 & 0.059 & 14.50 & 0.36 & 0.53 \\
Autozooecial aperture spacing diagonally, mm & 7 & 0.28 & 0.025 & 8.99 & 0.25 & 0.32 \\
Maximum chamber width, mm & 9 & 0.21 & 0.011 & 4.99 & 0.20 & 0.23 \\
\hline
\end{tabular}

TABLE 25. Measurements of Polypora brouweri Bassler, 1929. Abbreviations as for Table 1.

\begin{tabular}{lcccccc}
\hline & $\mathbf{N}$ & $\mathbf{X}$ & SD & CV & MIN & MAX \\
\hline Branch width, mm & 6 & 0.91 & 0.151 & 16.55 & 0.72 & 1.13 \\
Dissepiment width, mm & 3 & 0.48 & 0.035 & 7.27 & 0.45 & 0.52 \\
Fenestrule width, mm & 4 & 1.1 & 0.200 & 18.18 & 1.0 & 1.4 \\
Fenestrule length, mm & 3 & 3.1 & 0.814 & 26.56 & 2.5 & 4.0 \\
Distance between branch centres, mm & 6 & 1.94 & 0.191 & 9.83 & 1.80 & 2.25 \\
Autozooecial aperture width, mm & 20 & 0.14 & 0.009 & 6.91 & 0.12 & 0.16 \\
Autozooecial aperture spacing along branch, mm & 20 & 0.51 & 0.065 & 12.68 & 0.40 & 0.60 \\
Autozooecial aperture spacing diagonally, mm & 20 & 0.32 & 0.035 & 11.02 & 0.25 & 0.38 \\
Maximum chamber width, mm & 20 & 0.21 & 0.009 & 4.14 & 0.20 & 0.23 \\
\hline
\end{tabular}

versed by abundant small microacanthostyles. Heteromorphs not observed.

Remarks. Polypora brouweri Bassler, 1929 differs from P. principalis Gorjunova, 1975 from the Lower Permian of Pamir in having wider branches as well as larger fenestrules. Polypora brouweri differs from $P$. remota grandis Trizna, 1939 from the Lower Permian of Urals in having narrower branches (branch width $0.72-1.13 \mathrm{~mm}$ vs. 1.11$1.39 \mathrm{~mm}$ in $P$. remota grandis) and wider apertures (aperture width $0.12-0.16 \mathrm{~mm}$ vs. $0.11-0.13 \mathrm{~mm}$ in $P$. remota grandis). Polypora goldfussi Eichwald, 1860 , as described by Metz (1946) from the Permian of northern Tibet, corresponds to Polypora brouweri Bassler, 1929. The original species of Eichwald (1860), however, possesses cyclozooecia (Nikiforova, 1938).

Occurrence. Permian; northern Tibet. Lower Permian (Sakmarian-Artinskian); Timor. Zhongba Formation, Permian (upper Cisuralian-Guadalupian); Zhongba area of southwestern Tibet.

Polypora aff. voluminosa Trizna and Klautzan, 1961

Figure 19.1-6; Table 26

aff. 1961 Polypora voluminosa Trizna and Klautzan, p. 433, pl. 12, fig. 5, pl. 13, fig. 1 , text-figs. 26ab. aff. 1986 Polypora voluminosa Trizna and Klautzan, 1961; Morozova and Krutchinina, p. 106, pl. 40, fig. 2.

Material. SMF 23.184-SMF 23.187.

Exterior description. Reticulate colonies composed of moderately wide branches jointed by moderately wide dissepiments. Autozooecia arranged in 3-4 alternating rows on branches. Autozooecial apertures rounded to oval, 4-5 spaced per length of fenestrule. Fenestrules short, oval. Large nodes regularly spaced on the colony surface.

Interior description. Autozooecial chambers relatively short, generally rhombic to roughly hexagonal in the mid-tangential section. Superior hemisepta well-developed, slightly curved proximally. External laminated skeleton well-developed, traversed by abundant small microacanthostyles. Apparent reproductive heteromorphs in form of isolated zooecia with enlarged distal roofed chambers, occurring on obverse colony surface, 0.19$0.21 \mathrm{~mm}$ in diameter.

Remarks. The present species is similar to Polypora voluminosa Trizna and Klautzan, 1961 from the Lower Permian of Urals. However, that species lacks nodes on the reverse side of the colony. It is similar to $P$. subvoluminosa Krutchinina in Morozova and Krutchinina, 1986 from the Lower Perm- 

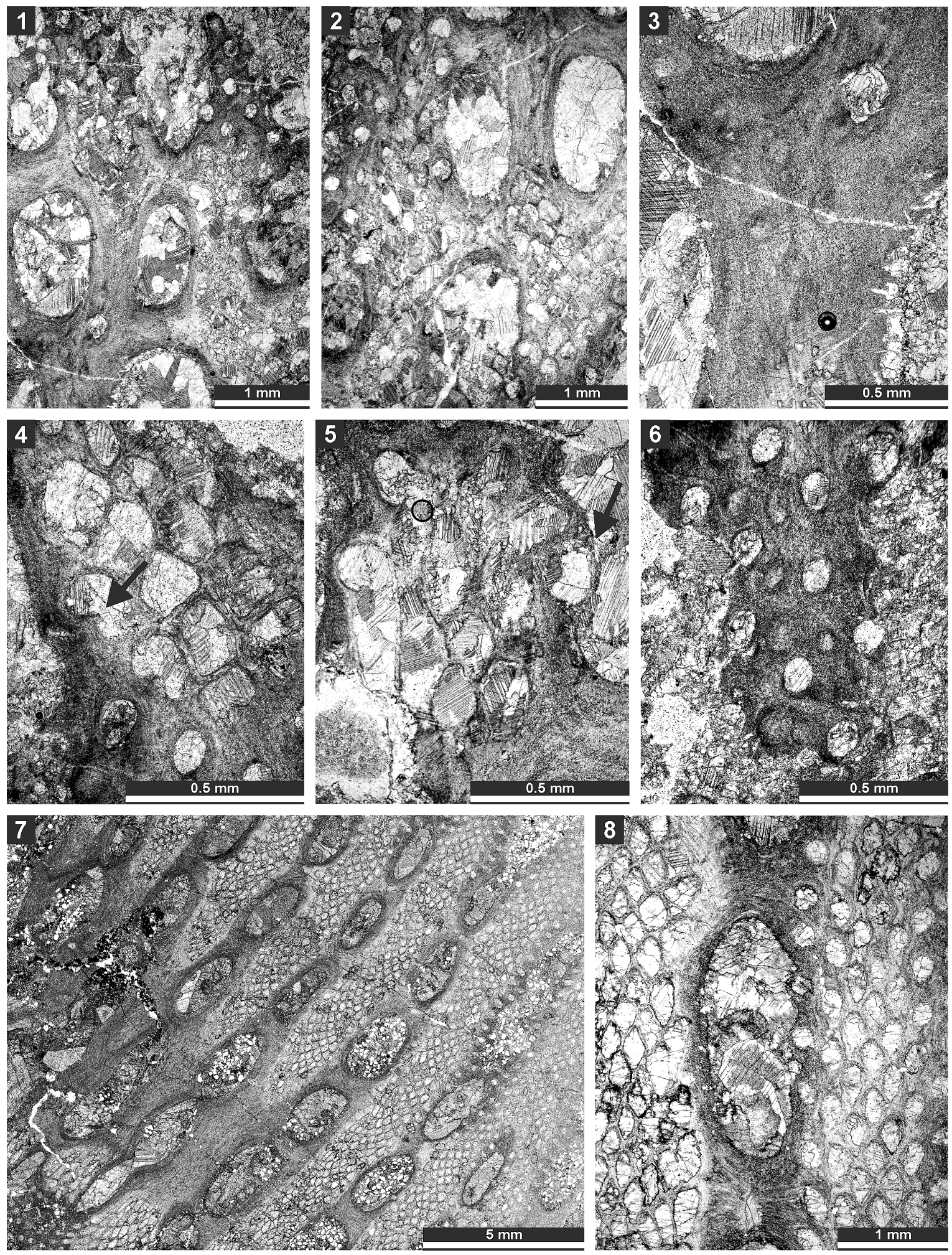

FIGURE 19. Thin section photographs of Polypora aff. voluminosa Trizna and Klautzan, 1961, SMF 23.187 (1-3, and 5) and SMF 23.185 (4 and 6); and Mackinneyella obesa (Crockford, 1957), SMF 23.191 (7) and SMF 23.192 (8). 1 and 2, tangential section branches and fenestrules; 3 , tangential section of the reverse side showing nodes; 4 , tangential section showing autozooecial apertures and chambers with hemisepta (arrow); 5, tangential section showing autozooecial apertures, chambers and heteromorph (arrow); 6, tangential section showing autozooecial apertures and nodes; and 7 and 8, tangential section showing autozooecial apertures and chambers. 
TABLE 26. Measurements of Polypora aff. voluminosa Trizna and Klautzan, 1961. Abbreviations as for Table 1.

\begin{tabular}{lcccccc}
\hline & $\mathbf{N}$ & $\mathbf{X}$ & $\mathbf{S D}$ & $\mathbf{C V}$ & MIN & MAX \\
\hline Branch width, mm & 8 & 0.85 & 0.153 & 17.92 & 0.67 & 1.02 \\
Dissepiment width, mm & 7 & 0.56 & 0.052 & 9.25 & 0.50 & 0.65 \\
Fenestrule width, mm & 6 & 0.62 & 0.066 & 10.77 & 0.53 & 0.70 \\
Fenestrule length, mm & 3 & 1.25 & 0.218 & 17.44 & 1.10 & 1.50 \\
Distance between branch centres, mm & 6 & 1.26 & 0.143 & 11.36 & 1.10 & 1.50 \\
Distance between dissepiment centres, mm & 7 & 1.90 & 0.312 & 16.44 & 1.63 & 2.38 \\
Autozooecial aperture width, mm & 30 & 0.11 & 0.006 & 5.57 & 0.10 & 0.12 \\
Autozooecial aperture spacing along branch, mm & 30 & 0.42 & 0.038 & 8.98 & 0.36 & 0.56 \\
Autozooecial aperture spacing diagonally, mm & 30 & 0.33 & 0.032 & 9.80 & 0.27 & 0.40 \\
Maximum chamber width, mm & 15 & 0.22 & 0.015 & 6.65 & 0.20 & 0.25 \\
Node diameter, obverse side, mm & 29 & 0.10 & 0.022 & 23.60 & 0.06 & 0.15 \\
Node diameter, reverse side, mm & 10 & 0.10 & 0.015 & 15.89 & 0.07 & 0.12 \\
\hline
\end{tabular}

ian of Arctic, but differs from the latter in having wider branches and larger fenestrules (branch width $0.67-1.02 \mathrm{~mm}$ vs. $0.45-0.60 \mathrm{~mm}$ in $P$. subvoluminosa; fenestrule width $0.53-0.70 \mathrm{~mm}$ vs. $0.50-$ $0.60 \mathrm{~mm}$ in $P$. subvoluminosa; fenestrule length $1.10-1.50 \mathrm{~mm}$ vs. $0.90-1.15 \mathrm{~mm}$ in $P$. subvoluminosa). Both of these species have well- developed superior hemisepta and a rhombic autozooecial chamber in mid-tangential section. Typical Polypora species have regularly hexagonal autozooecia and usually no distinct hemisepta. Representatives of Paucipora Termier and Termier, 1971 have distinct superior and inferior hemisepta dividing the hexagonal chambers in three parts.

Occurrence. ?Lower Permian (Artinskian); Russia (Urals). Zhongba Formation, Permian (upper Cisuralian-Guadalupian); Zhongba area of southwestern Tibet.

\section{Genus MACKINNEYELLA Morozova and Lisitsyn, 1996}

Type species. Polypora ornamentata SchulgaNesterenko, 1941. Lower Permian, southern Urals (Russia).

Diagnosis. Reticulated colonies of various shapes consisting of broad linear, essentially parallel branches joined by dissepiments; dissepiments narrow, perpendicular or at oblique angle to branches, regularly spaced at large distance; fenestrules elongate oval, sub-rectangular, or irregular in shape; keels and superstructure absent; autozooecia arranged in 5-6 rows on branches; chambers slightly elongate, proximally recumbent on budding plate, rhomboidal or rounded hexagonal in mid tangential section, long axis parallel with branch axis; hemisepta and diaphragms absent; granular skeleton present in basal plate and axial wall but locally absent in transverse and lateral autozooecial walls; extrazooecial skeleton laminated, traversed by abundant, moderate-size microstyles.

Remarks. Mackinneyella Morozova and Lisitsyn, 1996 differs from Polypora M'Coy, 1844 in having 5-6 autozooecial rows on branches instead of 3-4 and a rhombic vs. hexagonal autozooecia in midtangential section. Mackinneyella differs from Parapolypora Morozova and Lisitsyn, 1996 in having rhombic instead of hexagonal autozooecia.

Occurrence. Upper Devonian-Upper Permian; worldwide.

Mackinneyella obesa (Crockford, 1957)

Figures 19.7-8, 20.1-4; Table 27

1957

Polypora obesa Crockford, p. 67, pl. 19, fig. 4.

Material. SMF 23.188-SMF 23.194.

Exterior description. Robust reticulate colony with straight branches joined by wide dissepiments. Bifurcation common. Regular branches 1.7-2.1 $\mathrm{mm}$ wide, widening before bifurcation to 2.4-2.6 and narrowing after the bifurcation to 1.2$1.5 \mathrm{~mm}$. Autozooecia arranged in 5-9 alternating rows on branches. Apertures circular, arranged in regular alternating rows, $6-8$ spaced per fenestrule length. Fenestrules medium in size, elongate, subrectangular. Keels absent; nodes on the obverse side present, arranged irregularly between autozooecial apertures; large nodes on the reverse side present. Internal granular skeleton thick, welldeveloped, continuous in microstyles. Outer lamellar skeleton moderately thick. Large nodes on the reverse colony surface present.

Interior description. Autozooecia rhombic in midtangential section; with well-developed vestibule 

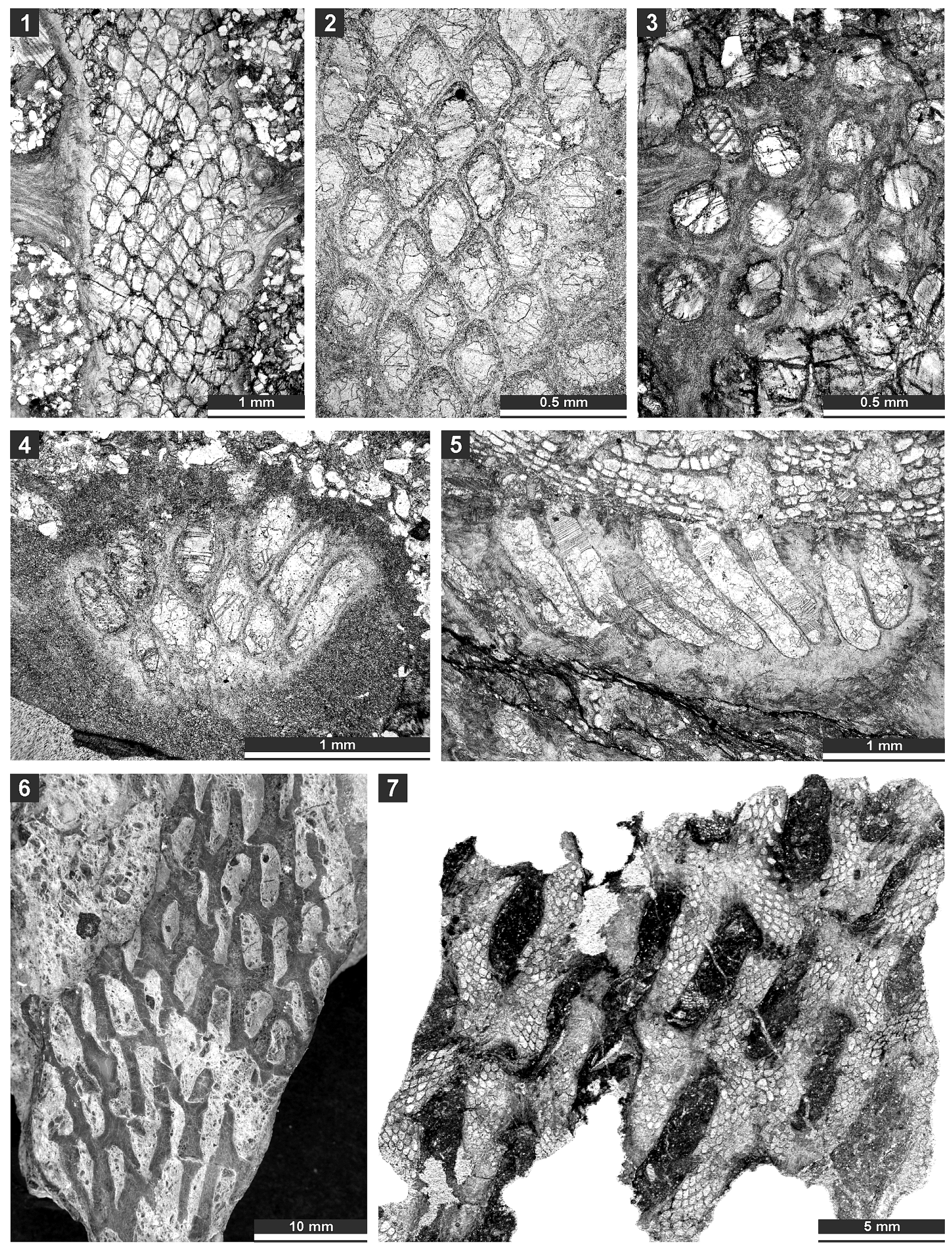

FIGURE 20. Thin section photographs of Mackinneyella obesa (Crockford, 1957), SMF 23.194 (1, 3), SMF 23.191 (2),

and SMF 23.189 (4); and Protoretepora irregularis n. sp., paratype SMF 23.198 (5), SMF 23.268 (6), and SMF 23.195 (7). 1-3, and 7, tangential section showing autozooecial chambers; 4 , branch transverse section; 5 , branch longitudinal section; and 6, external view of the reverse side of the colony. 
TABLE 27. Measurements of Mackinneyella obesa (Crockford, 1957). Abbreviations as for Table 1.

\begin{tabular}{lcccccc}
\hline & $\mathbf{N}$ & $\mathbf{X}$ & $\mathbf{S D}$ & $\mathbf{C V}$ & MIN & MAX \\
\hline Branch width, mm & 18 & 1.83 & 0.121 & 6.58 & 1.70 & 2.10 \\
Dissepiment width, mm & 23 & 0.86 & 0.112 & 13.00 & 0.67 & 1.08 \\
Fenestrule width, mm & 21 & 0.88 & 0.200 & 22.84 & 0.55 & 1.20 \\
Fenestrule length, mm & 25 & 1.96 & 0.219 & 11.20 & 1.50 & 2.30 \\
Distance between branch centres, mm & 16 & 2.55 & 0.297 & 11.63 & 1.75 & 3.00 \\
Distance between dissepiment centres, mm & 20 & 2.97 & 0.294 & 9.93 & 2.30 & 3.45 \\
Autozooecial aperture width, mm & 40 & 0.17 & 0.021 & 11.89 & 0.14 & 0.23 \\
Autozooecial aperture spacing along branch, mm & 40 & 0.45 & 0.041 & 9.00 & 0.36 & 0.51 \\
Autozooecial aperture spacing diagonally, mm & 40 & 0.30 & 0.034 & 11.53 & 0.24 & 0.38 \\
Maximum chamber width, mm & 40 & 0.23 & 0.017 & 7.25 & 0.20 & 0.27 \\
Node diameter, reverse side, mm & 20 & 0.16 & 0.028 & 17.32 & 0.12 & 0.20 \\
Node diameter, obverse side, mm & 10 & 0.08 & 0.018 & 22.05 & 0.05 & 0.10 \\
\hline
\end{tabular}

protruding highly above the colony surface; elongate to branch length; aperture positioned at distal end of chamber. Hemisepta absent. Heteromorphs absent.

Remarks. Mackinneyella obesa (Crockford, 1957) differs from $M$. ovalifenestrata Sakagami, 1964 from the Lower Permian of Japan by having wider branches (1.7-2.1 mm vs. $1.2-1.4 \mathrm{~mm}$ in $M$. ovalifenestrata). Mackinneyella obesa differs from $M$. granulosa Reid, 2003 by also having wider branches (average branch width $1.84 \mathrm{~mm}$ vs. 1.46 $\mathrm{mm}$ in M. granulosa). Mackinneyella obesa differs from M. brevicellata Baranova, 1960b from the Lower Permian of Russia by having wider branches (1.7-2.1 $\mathrm{mm}$ vs. $0.52-0.95 \mathrm{~mm}$ in $M$. brevicellata) and larger fenestrules (fenestrule width $0.55-1.20 \mathrm{~mm}$ vs. $0.47-0.72 \mathrm{~mm}$ in $M$. brevicellata; fenestrule length $1.50-2.30 \mathrm{~mm}$ vs. $1.66-$ $2.10 \mathrm{~mm}$ in M. brevicellata).

Occurrence. Noonkanbah Formation, Lower Permian (upper Artinskian-Kungurian); Western Australia. Zhongba Formation, Permian (upper Cisuralian-Guadalupian); Zhongba area of southwestern Tibet.

\section{Genus PROTORETEPORA de Koninck, 1878}

Type species. Protoretepora crockfordae Wyse Jackson, Reid and McKinney, 2011 (revised by Wyse Jackson, Reid and McKinney, 2012). Cascades Group, Lower Permian (late Artinskian-early Kungurian); Tasmania.

Diagnosis. Colony fan-shaped to conical, longitudinally pleated; branches broad, linear, essentially parallel, closely spaced, dichotomously dividing; regularly placed lateral expansions of branches fuse with those developed from adjacent branches to form circular to oval-shaped intermediate-sized fenestrules; additional extrazooecial skeleton may be present between autozooecial apertures at fusion points; lateral expansions depressed relative to main branch obverse and reverse surface; typically 5-6 rows of autozooecia per branch with fewer on lateral branch expansions; zooecial apertures circular, lacking peristomes, aligned longitudinally and diagonally in alternating rows; keels and large obverse styles absent, small styles common in interapertural skeleton; autozooecial chambers tubular, diverging from budding plate at an angle of $50-60^{\circ}$, with long axis directed toward obverse surface, laterally placed chambers inclined disto-laterally at acute or obtuse angle; zooecial chamber cross-sections polygonal or hexagonal in deep section parallel to base; rounded-polygonal in shallow section; hemisepta and diaphragms absent; large diameter distal tube short; reverse axial wall of varying thickness, granular skeleton present in basal plate and axial wall, basal plate with closely spaced fine ridges on reverse side; extrazooecial skeleton laminated, traversed by abundant, typically small styles closely spaced; heteromorphs not known (modified after Wyse Jackson et al., 2011).

Remarks. Proteretepora de Koninck, 1878 differs from Anastomopora Simpson, 1897 in the absence of exozonal tubes in autozooecia. Furthermore, Anastomopora shows a skeletal microstructure which implies an original aragonitic skeleton, whereas Protoretepora has a typical low-Mg calcite laminated skeleton.

Occurrence. Permian (Artinskian-Ufimian); Australia, Tasmania, Indonesia, Mongolia, Thailand.

Protoretepora irregularis n. sp.

Figures 20.5-7, 21.1-5; Table 28

zoobank.org/C6FD3035-7186-41C0-991C-0425C7478744 

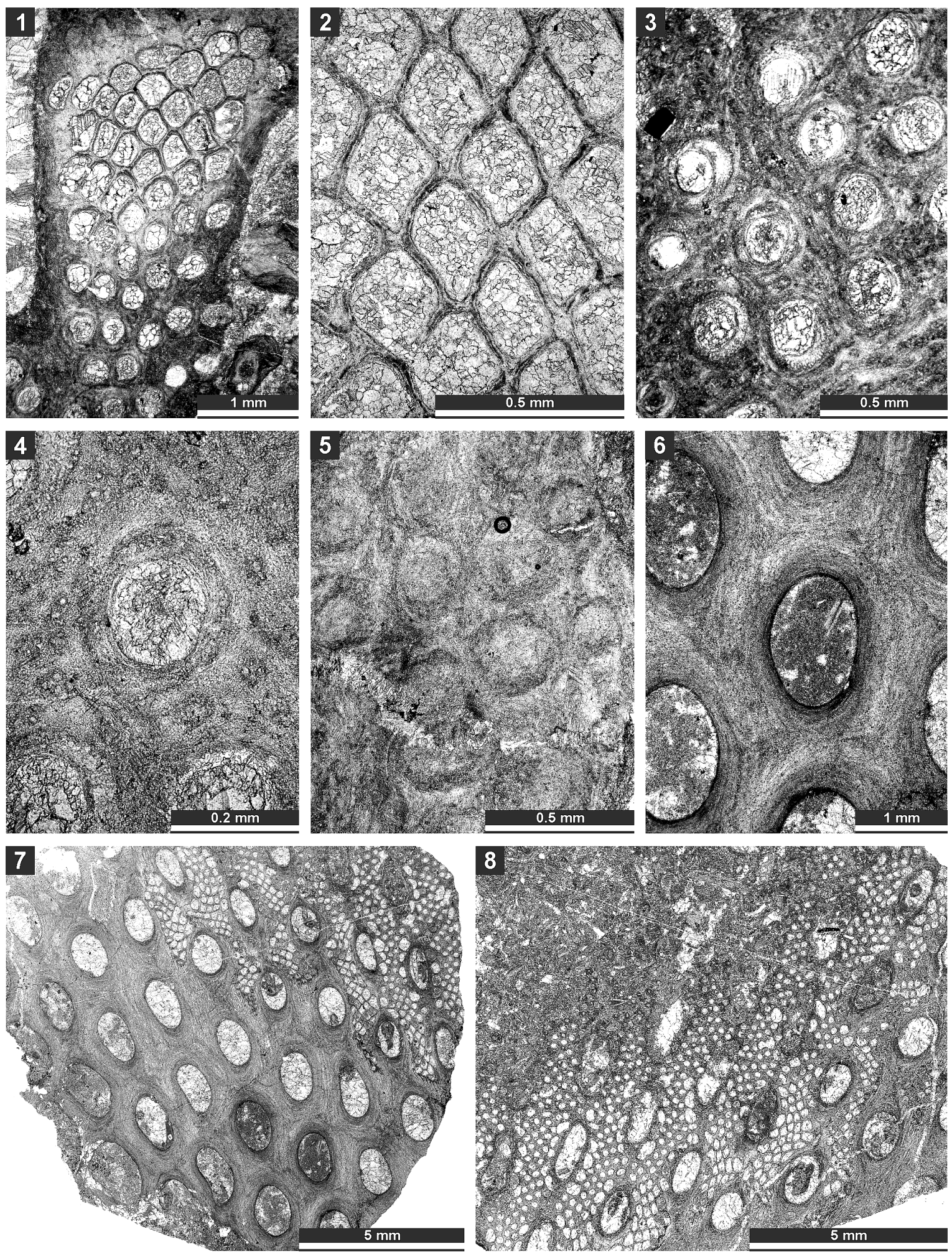

FIGURE 21. Thin section photographs of Protoretepora irregularis $n$. sp., paratype SMF 23.201 (1, 3, and 4), paratype SMF 23.202 (2), and holotype SMF 23.195 (5); and Tibetiporella ornata n. gen. n. sp., paratype SMF 23.224 (6 and 7) and holotype SMF 23.227 (8). 1, tangential section showing autozooecial apertures and chambers; 2 , mid-tangential section showing autozooecial chambers; $3,4,7$, and 8 , tangential section showing autozooecial apertures, microstyles and nodes; 5 , tangential section of obverse colony side with nodes; and 6 , tangential section of the reverse side of the colony. 
TABLE 28. Measurements of Protoretepora irregularis n. sp. Abbreviations as for Table 1.

\begin{tabular}{lcccccc}
\hline & $\mathbf{N}$ & $\mathbf{X}$ & SD & CV & MIN & MAX \\
\hline Branch width, mm & 20 & 1.8 & 0.332 & 18.21 & 1.2 & 2.5 \\
Fenestrule width, mm & 12 & 1.4 & 0.310 & 21.88 & 0.9 & 2.0 \\
Fenestrule length, mm & 7 & 3.9 & 1.212 & 31.19 & 2.0 & 5.5 \\
Autozooecial aperture width, mm & 40 & 0.18 & 0.017 & 9.94 & 0.14 & 0.20 \\
Autozooecial aperture spacing along branch, mm & 40 & 0.33 & 0.037 & 11.18 & 0.26 & 0.40 \\
Maximum chamber width, mm & 40 & 0.26 & 0.018 & 6.85 & 0.23 & 0.30 \\
Node diameter, reverse side, mm & 20 & 0.18 & 0.036 & 20.10 & 0.14 & 0.25 \\
\hline
\end{tabular}

Etymology. The species is named after its irregular colony shape

Holotype. SMF 23.195.

Paratypes. SMF 23.196-SMF 23.204, SMF 23.268.

Type locality. Zhongba area of southwestern Tibet (E 84.31536, N 29.74233).

Type stratum. Zhongba Formation, Permian (upper Cisuralian-Guadalupian).

Diagnosis. Irregular meshwork formed by broad branches; fenestrules large, irregularly oval to rectangular; autozooecia in 6-7 rows on branches; autozooecia rhombic in mid-tangential section; hemisepta absent; abundant microstyles arranged in rosette-like pattern; nodes spaced irregularly on the reverse colony surface; heteromorphs absent.

Exterior description. Reticulate colony formed by broad branches irregularly fused together; colony shape unknown. Fenestrules large, having irregularly oval to rectangular shape. Autozooecia arranged in 6-7 rows on branches. Autozooecial apertures circular, lacking peristomes. Keels absent. Nodes spaced irregularly on the reverse colony surface.

Interior description. Autozooecia rhombic in midtangential section, irregularly shaped at branch bifurcations; with well-developed vestibule protruding highly above the colony surface; elongate to branch length; aperture positioned at distal end of chamber. Hemisepta absent. Extrazooecial skeleton laminated, traversed by abundant microstyles. Microstyles $0.005-0.015 \mathrm{~mm}$ in diameter, generally arranged in a rosette-like pattern. Heteromorphs not observed.

Remarks. Protoretepora irregularis n. sp. is distinct by its broad branches, irregular meshwork and presence of large nodes on the reverse colony surface. Protoretepora irregularis differs from $P$. robusta Bassler, 1929 from the Permian of Timor by having large and irregularly shaped fenestrules as well as large nodes on the reverse surface. Protoretepora irregularis differs from $P$. flexuosa Crockford, 1957 from the Lower Permian of West- ern Australia by the presence of $6-7$ rows of autozooecia on branches instead of 4-5 rows in $P$. flexuosa. Furthermore, the new species has larger autozooecial apertures (average aperture width $0.18 \mathrm{~mm}$ vs. $0.13 \mathrm{~mm}$ in $P$. flexuosa).

Genus TIBETIPORELLA n. gen.

zoobank.org/F1631541-0817-4F68-A475-1CA0028A0AB3

Type species. Tibetiporella ornata $n$. gen. $n$. sp. Zhongba Formation, Permian (upper CisuralianGuadalupian); Zhongba area of southwestern Tibet.

Etymology. The genus is named after its occurrence in Tibet plus suffix - porella (feminine), meaning pored organism.

Diagnosis. Reticulate colonies consisting of broad linear branches joined by short and wide dissepiments; dissepiments narrow, perpendicular to branches, regularly spaced at large distance; fenestrules elongate oval, sub-rectangular, or irregular in shape; keels and superstructure absent; autozooecia arranged in 3-7 rows on branches; autozooecial apertures circular; autozooecial chambers long, narrow, tubular, with long vestibules, proximally recumbent on budding plate, rhomboidal in mid tangential section, long axis parallel with branch axis; hemisepta and diaphragms absent; granular skeleton present in basal plate and axial wall but locally absent in transverse and lateral autozooecial walls; extrazooecial skeleton thick, laminated, traversed by abundant, moderatesize microstyles; apparent reproductive heteromorphs in form of isolated zooecia with enlarged chambers in the proximal part of the vestibule, occurring on obverse colony surface; chambers rounded, oval to semicircular in tangential section; nodes and styles on the obverse colony surface present; reverse side smooth.

Remarks. Tibetiporella n. gen. differs from Mackinneyella Morozova and Lisitsyn, 1996 by having long autozooecia with long vestibules and heteromorphs in the form of enlarged chambers in the proximal part of vestibule. 

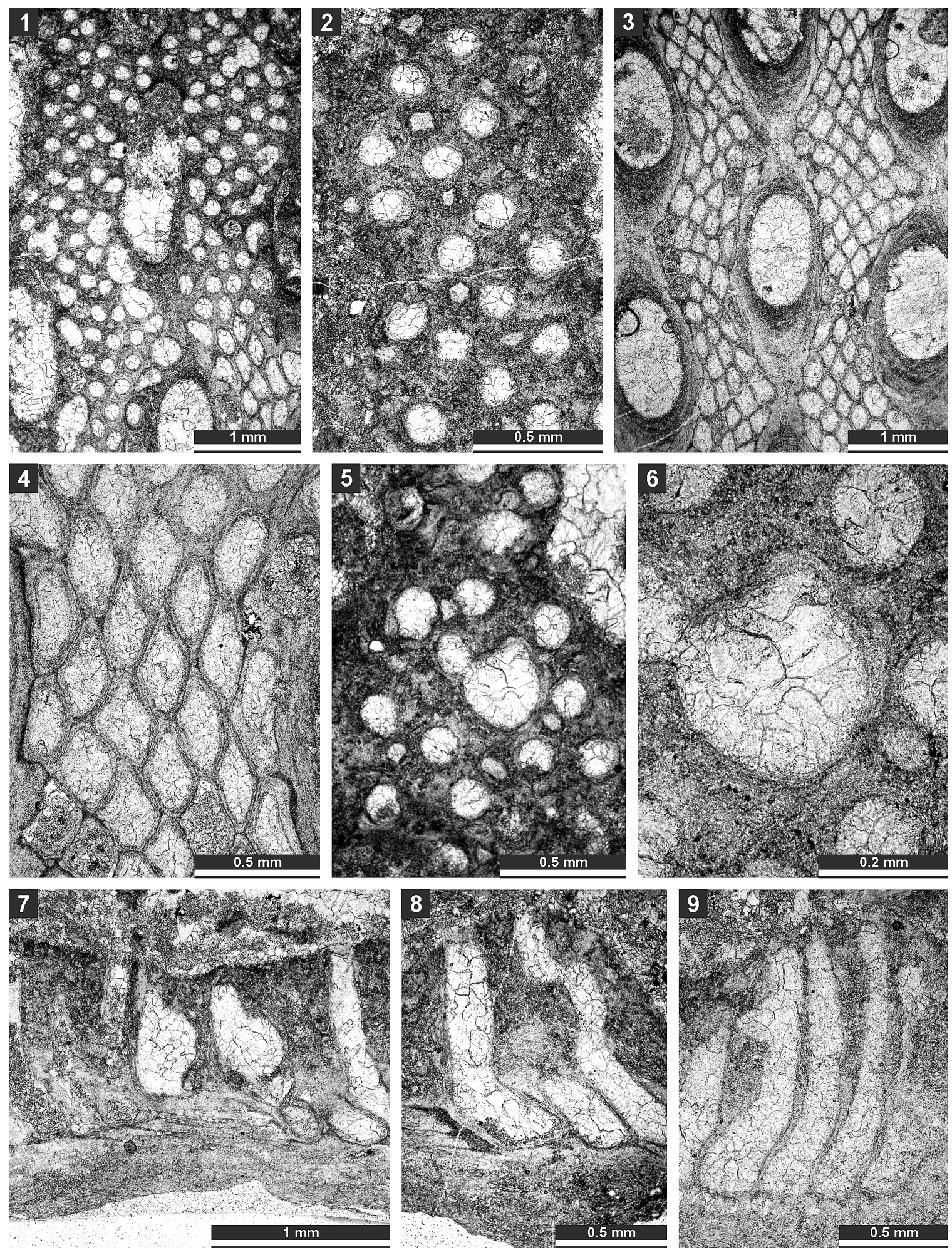

FIGURE 22. Thin section photographs of Tibetiporella ornata n. gen. n. sp., holotype SMF 23.227 (1 and 2), paratype SMF 23.211 (3 and 4), paratype SMF 23.210 (5 and 6), paratype SMF 23.213 (7 and 8), and paratype SMF 23.225 (9). 1 and 2, tangential section showing autozooecial apertures, nodes and heteromorphs; 3 and 4, mid-tangential section showing autozooecial chambers; 5 and 6 , tangential section showing autozooecial apertures, nodes and heteromorphs; 7 and 8 , longitudinal section showing autozooecial chambers and heteromorphs; and 9, transverse section showing autozooecial chambers. 
TABLE 29. Measurements of Tibetiporella ornata n. gen. n. sp. Abbreviations as for Table 1.

\begin{tabular}{lcccccc}
\hline & $\mathbf{N}$ & $\mathbf{X}$ & $\mathbf{S D}$ & $\mathbf{C V}$ & MIN & MAX \\
\hline Branch width, mm & 30 & 1.06 & 0.157 & 14.73 & 0.78 & 1.38 \\
Branch thickness & 10 & 1.87 & 0.308 & 16.42 & 1.40 & 2.25 \\
Dissepiment width, mm & 30 & 1.29 & 0.165 & 12.78 & 1.00 & 1.60 \\
Fenestrule width, mm & 30 & 0.60 & 0.090 & 15.01 & 0.45 & 0.79 \\
Fenestrule length, mm & 30 & 1.20 & 0.151 & 12.64 & 0.77 & 1.63 \\
Distance between branch centres, mm & 30 & 1.68 & 0.195 & 11.60 & 1.25 & 2.13 \\
Distance between dissepiment centres, mm & 30 & 2.54 & 0.123 & 4.84 & 2.40 & 2.85 \\
Autozooecial aperture width, mm & 30 & 0.14 & 0.011 & 7.70 & 0.12 & 0.16 \\
Autozooecial aperture spacing along branch, mm & 30 & 0.36 & 0.046 & 12.79 & 0.26 & 0.43 \\
Autozooecial aperture spacing diagonally, mm & 30 & 0.22 & 0.025 & 11.31 & 0.17 & 0.26 \\
Apertures per fenestrule length & 10 & 5.8 & 0.789 & 13.60 & 5.0 & 7.0 \\
Maximum chamber width, mm & 30 & 0.21 & 0.017 & 8.12 & 0.18 & 0.25 \\
Node diameter, mm & 30 & 0.09 & 0.018 & 20.85 & 0.05 & 0.12 \\
Heteromorph width, mm & 30 & 0.30 & 0.045 & 15.07 & 0.24 & 0.41 \\
\hline
\end{tabular}

Occurrence. Zhongba Formation, Permian (upper Cisuralian-Guadalupian); Zhongba area of southwestern Tibet.

Tibetiporella ornata n. gen. n. sp

Figures 21.6-8, 22.1-9; Table 29

zoobank.org/D85111C2-1B35-45F2-8278-80137807B6C5

Etymology. The species is named after rich ornamentation due to various styles on the obverse colony surface (after Latin "ornata" = adorned, decorated).

Holotype. SMF 23.227.

Paratypes. SMF 23.209-SMF 23.213, SMF 23.224-SMF 23.226, SMF 23.228, SMF 23.229.

Type locality. Zhongba area of southwestern Tibet (E 84.31111, N 29.73889).

Type stratum. Zhongba Formation, Permian (upper Cisuralian-Guadalupian).

Diagnosis. See genus diagnosis.

Exterior description. Reticulate colony formed by broad branches fused together; colony shape unknown. Autozooecia arranged in 3-7 rows on branches. Autozooecial apertures circular, 6-7 apertures spaced per fenestrule length. Large nodes on the obverse colony surface, $0.05-0.12$ $\mathrm{mm}$ in diameter. Smaller styles irregularly arranged, $0.025-0.030 \mathrm{~mm}$ in diameter. Reverse colony side smooth.

Interior description. Autozooecial chambers long, narrow, tubular, with long vestibules, proximally recumbent on budding plate, rhomboidal in midtangential section, long axis parallel with branch axis. Hemisepta and diaphragms absent. Extrazooecial skeleton thick, laminated, traversed by abundant, moderate-size microstyles $0.003-0.006$ $\mathrm{mm}$ in diameter. Apparent reproductive heteromorphs in the form of isolated zooecia with enlarged chambers in the proximal part of the vestibule, occurring on obverse colony surface. Chambers rounded, oval to semicircular in tangential section, $0.24-0.41 \mathrm{~mm}$ wide.

Remarks. See genus diagnosis and remarks.

\section{DISCUSSION}

\section{Palaeobiogeography and Stratigraphy}

The bryozoan fauna of the Zhongba Formation shows high diversity and abundance. Taxa comprising this fauna belong to orders Cystoporata, Trepostomata, Cryptostomata, and Fenestrata. In total, 30 species of 25 genera were identified.

Cystoporate bryozoans (11 species of nine genera): Fistulipora enodata Gorjunova, 1970, F. guttata Trizna and Klautzan, 1961, F. sakagamii n. sp., Dybowskiella hupehensiformis n. sp., Fistuliramus xianzaensis Liu and Wang, 1987, Eridopora uncata Yang and Lu, 1983, Cyclotrypa alexanderi Sakagami, 1963, Hexagonella kobayashii Sakagami, 1968, Goniocladia aff. indica Waagen and Pichl, 1885, Liguloclema meridianus (Etheridge, 1926), and Etherella tibetensis n. sp.

Trepostome bryozoans (four species of four genera): Tabulipora xinjiangensis Yang and Lu, 1983, Dyscritella lii n. sp., Ulrichotrypella omanica Ernst et al., 2008, and Neoeridotrypella astrica (Linskaya, 1951). 
TABLE 30. Matrix of occurrences of bryozoan species from the Zhongba Formation used for the numerical plots in the Figure 23 (1 - present, 0 - absent). Thailand and Western Australia share the hightest number of species with the Zhongba area (five and four species, respectively), whereas other regions share three or fewer species with the studied area.

\begin{tabular}{|c|c|c|c|c|c|c|c|c|c|c|}
\hline & $\begin{array}{c}\text { Zhongba } \\
\text { Fm. }\end{array}$ & Xainza & Pamir & Thailand & $\begin{array}{c}\text { W- } \\
\text { Australia }\end{array}$ & Timor & Urals & Oman & Xinjiang & Iran \\
\hline Fistulipora enodata & 1 & 1 & 1 & 0 & 0 & 0 & 0 & 0 & 0 & 0 \\
\hline Fistulipora guttata & 1 & 0 & 0 & 0 & 0 & 0 & 1 & 0 & 0 & 0 \\
\hline Fistulipora sakagamii & 1 & 0 & 0 & 1 & 0 & 0 & 0 & 0 & 0 & 0 \\
\hline Dybowskiella hupehensiformis & 1 & 0 & 0 & 0 & 0 & 0 & 0 & 0 & 1 & 0 \\
\hline Fistuliramus xianzaensis & 1 & 1 & 0 & 0 & 0 & 0 & 0 & 0 & 0 & 0 \\
\hline Eridopora uncata & 1 & 0 & 0 & 0 & 0 & 0 & 0 & 0 & 1 & 0 \\
\hline Cyclotrypa alexanderi & 1 & 0 & 0 & 0 & 1 & 0 & 0 & 0 & 0 & 0 \\
\hline Hexagonella kobayashii & 1 & 0 & 0 & 1 & 0 & 0 & 0 & 1 & 0 & 0 \\
\hline Liguloclema meridianus & 1 & 1 & 0 & 1 & 1 & 0 & 0 & 0 & 0 & 0 \\
\hline Tabulipora xinjiangensis & 1 & 0 & 0 & 0 & 0 & 0 & 0 & 0 & 1 & 0 \\
\hline Ulrichotrypella omanica & 1 & 0 & 0 & 0 & 0 & 0 & 0 & 1 & 0 & 0 \\
\hline Neoeridotrypella astrica & 1 & 0 & 0 & 0 & 0 & 0 & 1 & 0 & 0 & 0 \\
\hline S.(S.) delicatula & 1 & 0 & 0 & 1 & 0 & 0 & 0 & 1 & 0 & 0 \\
\hline S. (S.) marmionensis & 1 & 0 & 1 & 0 & 1 & 0 & 0 & 1 & 0 & 1 \\
\hline Rhabdomeson bretnalli & 1 & 0 & 0 & 0 & 1 & 0 & 0 & 0 & 0 & 0 \\
\hline Primorella rotunda & 1 & 0 & 1 & 0 & 0 & 0 & 0 & 1 & 0 & 1 \\
\hline Timanotrypa australis & 1 & 0 & 0 & 1 & 0 & 0 & 0 & 0 & 0 & 0 \\
\hline $\begin{array}{l}\text { Spinofenestella } \\
\text { subquadratopora }\end{array}$ & 1 & 0 & 0 & 0 & 0 & 0 & 1 & 0 & 0 & 0 \\
\hline Polypora consanguinea & 1 & 0 & 0 & 0 & 0 & 1 & 0 & 0 & 0 & 0 \\
\hline Polypora brouweri & 1 & 0 & 0 & 0 & 0 & 1 & 0 & 0 & 0 & 0 \\
\hline Mackinneyella obesa & 1 & 0 & 0 & 0 & 0 & 1 & 0 & 0 & 0 & 0 \\
\hline
\end{tabular}

Cryptostome bryozoans (seven species of five genera): Streblotrypa (Streblotrypa) parviformis $\mathrm{n}$. sp., Streblotrypa (Streblascopora) delicatula Sakagami, 1961, Streblotrypa (Streblascopora) marmionensis (Etheridge, 1926), Rhabdomeson bretnalli Crockford, 1957, Rhabdomeson sp., Primorella rotunda Gorjunova, 1985, and Timanotrypa australis n. sp.

Fenestrate bryozoans (eight species of five genera): Spinofenestella sp., Spinofenestella subquadratopora (Schulga-Nesterenko, 1952), Polypora consanguinea Bassler, 1929, Polypora brouweri Bassler, 1929, Polypora aff. voluminosa Trizna and Klautzan, 1961, Mackinneyella obesa (Crockford, 1957), Protoretepora irregularis n. sp., and Tibetiporella ornata n. gen. n. sp.

The majority of bryozoans from the Zhongba Formation of southwestern Tibet have a Lower Permian (Artinskian-Kungurian) distribution in such regions as Thailand, Oman, Western Australia, Timor, the Urals, Pamir, Iran, and two localities in southwestern China (Table 30 ).

The distribution matrix from the Table 30 was used for the cluster analysis (Jacquard's similarity index, unweighted pair-group average algorithm). The computed dendrogram suggests the closest relation of the Zhongba fauna is that of Thailand (Figure 23). These two faunas show similarity to the cluster formed by Western Australia and Xainza, and together they build a cluster that shows similarity to the cluster Oman plus Pamir and Iran. All these regions show decreasing similarity to Timor, Urals and Xinjiang.

Reid and James $(2008,2010)$ compared the Permian bryozoan diversity of Gondwana and northern Eurasia and concluded that Permian bryozoan faunas from higher latitudes (antitropical) showed lower diversity than those from the tropics. 

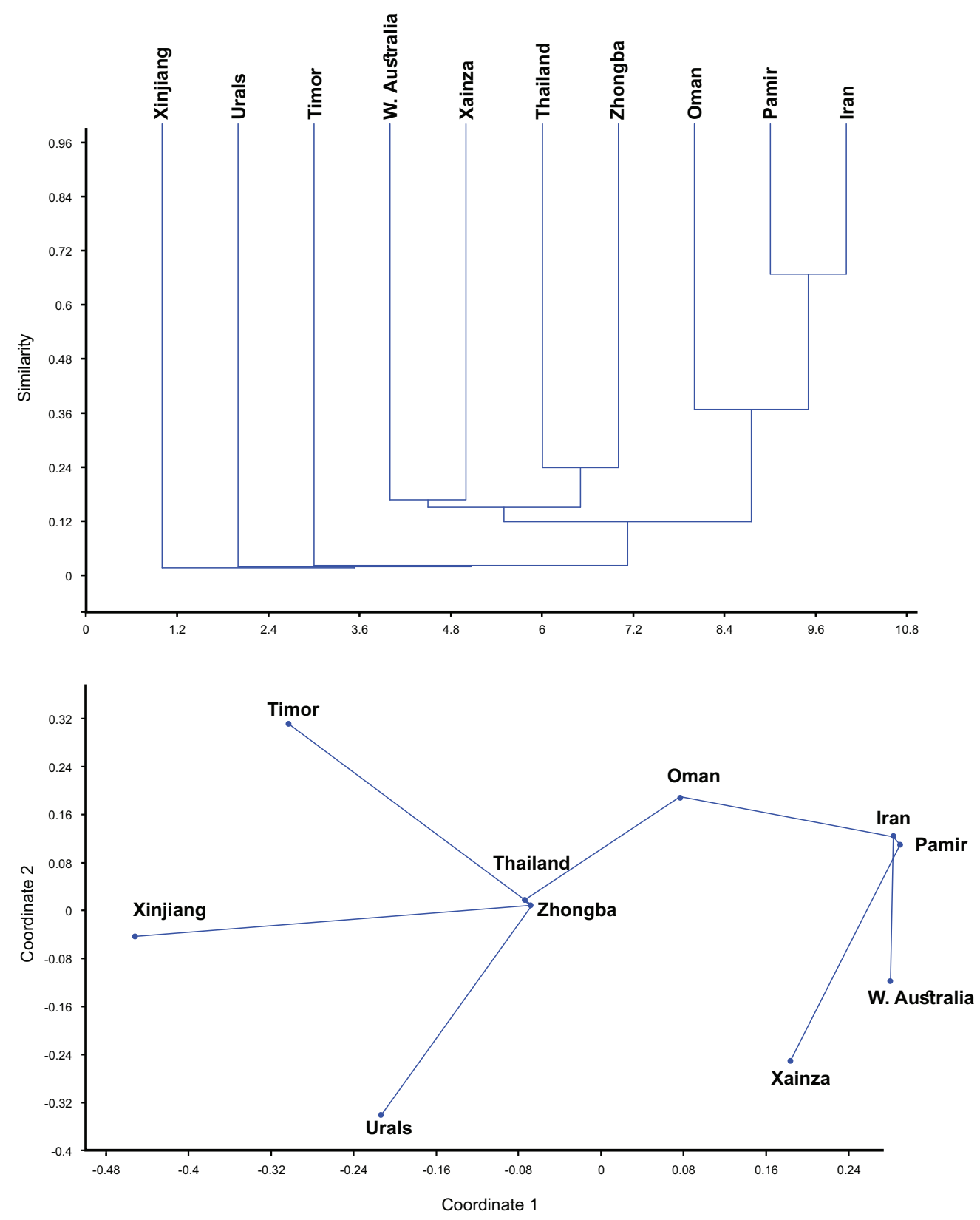

Figure 23. Palaeobiogeographical affinities of the bryozoan assemblage from the Zhongba Formation (Zhongba). Top: dendrogram of the cluster analysis using Jacquard's similarity index (unweighted pair-group average algorithm), and bottom: plot of non-metric MDS analysis made with Jacquard's similarity index. Areas: Pamir (Tajikistan), Oman (Batain Coast), Iran (central Iran, Chili Formation), Xainza (southwestern Tibet, Xiala Fm.), Thailand, Urals, Western Xinjiang (Baliqliq Group), and W. Australia (Noonkanbah Fm.). Japan, Malaysia, and Rutog (southwestern Tibet) were omitted as sharing only one species with Zhongba assemblage.

The Zhongba area of southwestern Tibet belongs to the central Tethys (Ross, 1995) and is clearly a tropical region. The taxonomic composition of the bryozoan fauna from the Zhongba Formation shows an intermixture of both Boreal and Gondwana elements. This fact indicates that there might be faunal migrations into the tropical region from both from the north and south.

Brachiopods found in the Zhongba Formation along with bryozoans include the following species (Li et al., 2014b): Stenoscisma gigantea (Diener, 1897), Spiriferella sinica Zhang, 1976, S. rajah (Salter, 1865), Costiferina alata Waterhouse, 1966, 
TABLE 31. Distribution of bryozoan growth forms in the Zhongba Formation.

\begin{tabular}{|c|c|}
\hline Species & Growth form \\
\hline Fistulipora enodata & encrusting \\
\hline Fistulipora guttata & encrusting \\
\hline Fistulipora sakagamii & encrusting \\
\hline $\begin{array}{l}\text { Dybowskiella } \\
\text { hupehensiformis }\end{array}$ & encrusting \\
\hline Eridopora uncata & encrusting \\
\hline Tabulipora xinjiangensis & encrusting \\
\hline Dyscritella lii & encrusting \\
\hline Cyclotrypa alexanderi & encrusting/branched \\
\hline Hexagonella kobayashii & branched/bifoliate/lenticular \\
\hline Liguloclema meridianus & branched/bifoliate/lenticular \\
\hline Timanotrypa australis & branched/bifoliate/lenticular \\
\hline Fistuliramus xianzaensis & branched/cylindrical \\
\hline Ulrichotrypella omanica & branched/cylindrical \\
\hline Neoeridotrypella astrica & branched/cylindrical \\
\hline $\begin{array}{l}\text { Streblotrypa (Streblotrypa) } \\
\text { parviformis }\end{array}$ & branched/cylindrical \\
\hline $\begin{array}{l}\text { Streblotrypa } \\
\text { (Streblascopora) delicatula }\end{array}$ & branched/cylindrical \\
\hline $\begin{array}{l}\text { Streblotrypa } \\
\text { (Streblascopora) } \\
\text { marmionensis }\end{array}$ & branched/cylindrical \\
\hline Rhabdomeson bretnalli & branched/cylindrical \\
\hline Rhabdomeson sp. & branched/cylindrical \\
\hline Primorella rotunda & branched/cylindrical \\
\hline Spinofenestella sp. & reticulate/connected/biserial \\
\hline $\begin{array}{l}\text { Spinofenestella } \\
\text { subquadratopora }\end{array}$ & reticulate/connected/biserial \\
\hline Polypora consanguinea & $\begin{array}{l}\text { reticulate/connected/ } \\
\text { multiserial }\end{array}$ \\
\hline Polypora brouweri & $\begin{array}{l}\text { reticulate/connected/ } \\
\text { multiserial }\end{array}$ \\
\hline Polypora aff. voluminosa & $\begin{array}{l}\text { reticulate/connected/ } \\
\text { multiserial }\end{array}$ \\
\hline Mackinneyella obesa & $\begin{array}{c}\text { reticulate/connected/ } \\
\text { multiserial }\end{array}$ \\
\hline Goniocladia aff. indica & $\begin{array}{c}\text { reticulate/fused/bifolate/ } \\
\text { multiserial }\end{array}$ \\
\hline Etherella tibetensis & $\begin{array}{c}\text { reticulate/fused/bifoliate/ } \\
\text { lenticular }\end{array}$ \\
\hline Protoretepora irregularis & reticulate/fused/multiserial \\
\hline Tibetiporella ornata & reticulate/fused/multiserial \\
\hline
\end{tabular}

and Enteletes waageni Gemmellaro, 1892. These species indicate a rather younger age (Guadalupian-Lopingian) than the bryozoan fauna (Artinskian-Kungurian). Accordingly, biostratigraphical interpretation does not correspond to the data on bryozoans. Enteletes waageni Gemmellaro, 1892 was originally described from the Permian on Sicily, and later recorded from the Chitichun Limestone (southern Tibet), Middle and Upper Productus Limestone (Pakistan), and Guadalupian (Djebel Tebaga, Tunisia) (Verna et al., 2010). Other species are known mainly from the Upper Permian of Nepal and Northern Himalaya (Waterhouse, 1966; Shen and Yugan, 1999). The age contradiction between bryozoans and brachiopods could be explained by the fact that the bryozoan samples were sampled from the lower part of the Zhongba Formation, whereas brachiopods were collected from the upper part of the formation (Xianghui Li, personal commun., 2015).

\section{Palaeoecology}

The studied bryozoan fauna shows a great variety of growth forms, which correspond to certain functionalities. Distribution of bryozoan growth forms is controlled by extrinsic factors (e.g., Stach, 1936; McKinney and Jackson, 1989; Smith, 1995; Hageman et al., 1997, 1998; Amini et al., 2004). Therefore, an analysis of bryozoan growth forms in a palaeocommunity may reveal import insights in the palaeoenvironment. However, a taphonomic impact must be considered because bryozoan skeletons react selectively to various sea-floor processes such as abrasion or dissolution (Smith and Nelson, 1994).

The bryozoan association of the Zhongba Formation contains three main groups of growth forms (Table 31): encrusting (8), erect branched (13) and erect reticulate (10). One species, Cyclotrypa alexanderi, can develop both encrusting and branched ramose colonies. Erect branches can be divided in branched/cylindrical (10) and branched/lenticular (3). Reticulate bryozoans show greater diversity in their construction modes: reticulate/connected/ (biserial-multiserial) (6), reticulate/fused/multiserial (3), and reticulate/fused/bifoliate/lenticular (1). The mode of the connection of branches in reticulate colonies may occur in two ways: by connection with dissepiments consisting of extrazooecial skeleton (connected) and by fusing (anastomosing) of undulating branches (fused). Furthermore, the branches may be unifoliate (apertures open on one side of branches, opposite side sterile) or bifoliate (apertures open both on obverse and reverse side of branches). The branches may bear two rows of zooecia (biserial) or three and more (multiserial).

From these growth forms, the encrusting colonies are the most universal, being adapted to various substrates and surviving also in moderate to high energy conditions (e.g., Nelson et al., 1988; 
McKinney and Jackson, 1989; Amini et al., 2004). Reticulate colonies may occur in a variety of hydrodynamic conditions (e.g., Stach, 1936; Pedley, 1976, Cuffey and McKinney, 1982), whereas erect branched colonies (especially the robust ones) are considered vulnerable to damage in high energy conditions (Cheetham and Thomsen, 1981). The lithological characteristics of embedding rocks (Figure 2) indicate a moderate to high energy environment. Absence of terrigenous material indicates a large distance from the shoreline. At least the encrusting bryozoans seem to be autochthonous in this association (Figure 2.2-3); other groups show a rather low to moderate fragmentation level indicating a relatively short transport distance of the debris. The lithology, bryozoan growth form distribution and composition of the accompanying fauna (brachiopods, crinoids, gastropods) suggest a middle shelf setting, an environment quite remote from the shoreline and influenced by local currents.

\section{CONCLUSIONS}

The described bryozoan fauna from the Zhongba Formation of the Zhongba area (southwestern Tibet) supports the early Permian (Cisuralian, Artinskian-Kungurian) age of this formation. Bryozoan fauna from the Zhongba Formation shows rather close relationships to Thailand and Western Australia, and some distant relations to Oman, Timor, central Pamir, Iran, Urals, and other Tibetan localities displaying an intermixture of both Boreal and Gondwana elements. These results contradict the interpretation of brachiopod species found in the Zhongba Formation, which indicate Guadalupian to Lopingian age and suggest connections to northern Himalaya and Nepal. This discrepancy may be explained by different levels of sampling within the Zhongba Formation. The distribution of bryozoan growth forms as well as the lithological characteristics and accompanying fauna suggests a middle shelf setting some distance from shoreline likely influenced by local currents.

\section{ACKNOWLEDGEMENTS}

Dr. X. Li, Department of Earth Sciences of Nanjing University, China, is thanked greatly for providing the bryozoan collection for study and helpful comments during the manuscript writing. This work is thanks to projects (12112011086037 and 1212011121229) aiminging the 1:50,000 geological mapping of Zhongba area fund by the Chinese Bureau of Geological Survey. E. Gilmour, Washington, and P. Wyse Jackson, Dublin, are thanked for helpful comments to the bryozoan taxonomy. C. Reid, Christchurch and H. Arne Nakrem, Olso provided helpful comments to the manuscript. Three anonymous referees are thanked for their constructive and helpful reviews of the manuscript. The study of Permian bryozoans is supported by the Deutsche Forschungsgemeinschaft (DFG), project ER 278/7.1 and 2.

\section{REFERENCES}

Amini, Z.Z., Adabi, M.H., Burrett, C.F., and Quilty, P.G. 2004. Bryozoan distribution and growth form associations as a tool in environmental interpretation, Tasmania, Australia. Sedimentary Geology, 167(1-2):115.

Astrova, G.G. 1960. Silurian fistuliporids from northern territories of USSR. Trudy Komy Filiala Akademii Nauk SSSR, Syktyvkar, 1:352-376. (In Russian)

Astrova, G.G. 1964. Novyi otryad paleozoiskikh mshanok [New Order of Paleozoic Bryozoa]. Paleontologicheskii Zhurnal, 1959 (1):22-31. (In Russian)

Astrova, G.G. 1965. Morphology, history of development and system of the Ordovician and Silurian Bryozoa. Trudy Paleontologicheskogo Instituta Akademii Nauk SSSR, 106:1-432. (In Russian)

Astrova, G.G. 1978. Historical development, systematics and phylogeny of Bryozoa. Order Trepostomata. Trudy Paleontologischeskogo Instituta Akademiya Nauk SSSR, 169:1-240. (In Russian)

Astrova, G.G. and Morozova, I.P. 1956. On systematics of the bryozoans of the Order Cryptostomata. Doklady Akademii Nauk SSSR, 110(4):661-664. (In Russian)

Baranova, G.I. 1960a. Some Early Permian Bryozoa of the Pechora River Basin. Paleontologicheskii Zhurnal 1960, (1):62-72. (In Russian)

Baranova, G.I. 1960b. New Early Permian bryozoans of the Pechora River Basin, p. 263-268. In Markowskii, B.P. (ed.), New species of fossil plants and invertebrates of the USSR, v. 1. VSEGEI, Moscow. (In Russian)

Bancroft, A.J. 1987. Biostratographical potential of Carboniferous Bryozoa. Courier Forschungsinstitut Senkenberg, 98:193-197.

Bassler, R.S. 1929. The Permian Bryozoa of Timor. Paläontologie von Timor, 16:37-90.

Borg, F. 1926. Studies on Recent cyclostomatous Bryozoa. Zoologiska Bidrag från Uppsala, 10:181-507.

Bretnall, R.W. 1926. Description of some western Australian fossil Polyzoa. Bulletin of Western Australia Geological Survey, 88:7-33.

Cheetham, A.X. and Thomsen, E. 1981. Functional morphology of arboresent animals: strength and design of cheilostome bryozoan skeletons. Paleobiology, 7:355-383.

Condra, G.E. 1902. New Bryozoa from the Coal Measures of Nebraska. The American Geologist, 30:337358. 
Crockford, J. 1944. Bryozoa from the Permian of Western Australia. Part I. Cyclostomata and Cryptostomata from the north-west basin and Kimberly district. Proceedings of the New South Wales Linnean Society, 69:139-175.

Crockford, J. 1945. Stenoporids from the Permian of New South Wales and Tasmania. Proceedings of the New South Wales Linnean Society, 70:9-24.

Crockford, J. 1947. Bryozoa from the Lower Carboniferous of New South Wales and Queensland. Proceedings of the New South Wales Linnean Society, 72:148.

Crockford, J. 1957. Permian Bryozoa from the Fitzroy Basin, Western Australia. Bulletin of Bureau of Mineral Resources, Australia, Geology and Geophysics, 34:9-131.

Cuffey, R.J. 1977. Bryozoan contributions to reefs and bioherms through geologic time. Studies in Geology, 4:181-194.

Cuffey, R.J. and McKinney, F.K. 1982. Reteporid cheilostome bryozoans from the modern reefs of Enewetak Atoll, and their implications for Paleozoic fenestrate bryozoan paleoecology. Pacific Geology, 16:7-13.

Dai, J., Wang, C., Hébert, R., Li, Y., Zhong, H., Guillaume, R., Bezard, R., and Wie, Y. 2011. Late Devonian OIB alkaline gabbro in the Yarlung Zangbo suture zone: remnants of the Paleo-Tethys? Gondwana Research, 19(1):232-243.

de Koninck, L.G. 1878. Recherches sur les fossils Paléozoïques de la Nouvelle-Galles du Sud (Australie). Troisiéme Parties. Fossiles Carboniferé res. Mémoires de la Société des Sciences de Liége, Series 2, 7:29-45. (In French)

Diener, C. 1897. The Permo-Carboniferous Fauna of Chiticun No. 1. Palaeontologica Indica, Series 15, 1(3):1-105.

Dunaeva, N.N. and Morozova, I.P. 1967. Evolution and systematic position of certain Late Paleozoic Trepostomata. Paleontologicheskii Zhurnal 1967, (4):86-94. (In Russian)

Ehrenberg, C.G. 1831. Animalia invertebrata exclusis insects. Symbolae Physicae, seu Icones et descriptiones Corporum Naturalium novorum aut minus cognitorum. Pars Zoologica. Mittler, Berlin. (In Latin)

Eichwald, E. 1860. Lethaea Rossica, ou Paléontologie de la Russie. I. Ancienne Période. E. Schweizerbart, Stuttgart. (In French)

Elias, M.K. and Condra, G.E. 1957. Fenestella from the Permian of west Texas. Geological Society of America Memoir, 70:158.

Engel, B.A. and Ross, J.R.P. 1993. Bryozoa. Geological Survey of Western Australia, Bulletin, 136:34-44.

Ernst, A. 2000. Permian bryozoans of the NW Tethys. Facies, 43:79-102.

Ernst, A. and Gorgij, M.N. 2013. Lower Permian bryozoan faunas from Kalmard area, central Iran. Neues Jahrbuch für Geologie und Paläontologie, Abhandlngen, 268(3):275-324.
Ernst, A. Weidlich, O., and Schäfer, P. 2008. Stenolaemate Bryozoa from the Permian of Oman. Journal of Paleontology, 82 (4):676-716.

Etheridge, R. 1873. Description of Carinella, a new genus of Carboniferous Polyzoa. Geological Magazine, 10:433-434.

Etheridge, R. Jr. 1875. Note on a new provisional genus of Carboniferous Polyzoa. Annals and Magazine of Natural History: Series 4, 15:43-45.

Etheridge, R. 1876. Notes on some Upper Palaeozoic Polyzoa. Transactions and Proceedings of the Royal Society of Victoria, 12:66-68.

Fleming, J. 1828. A History of British Animals, Exhibiting Their Descriptive Characters and Systematic Arrangement of the Genera and Species of Quadrupeds, Birds, Reptiles, Fishes, Mollusca, and Radiata of the United Kingdom. Bell \& Bradfute, Edinburgh.

Gemmellaro, G.G. 1892. Sopra due famiglie di Brachiopodi (Strophomenidae e Productidae) provenienti dai calcari con Fusulina della valle del fiume Sosio nella Provincia di Palermo. Societa di Scienze Naturali ed Economiche di Palermo, Bollettino, 3:23-27. (In Italian)

Gilmour, E.H., McColloch, M.E., and Wardlaw, B.R. 1997. Bryozoa of the Murdock Mountain Formation (Wordian, Permian), Leach Mountains, Northeastern Nevada. Journal of Paleontology, 71(2):214-236.

Gilmour, E.H. and Morozova, I.P. 1999. Biogeography of the Upper Permian bryozoans. Paleontological Journal, 33(1):36-51.

Gilmour, E.H. and Snyder, E.M. 1986. Stellahexiformis and Morozoviella, two new genera of Bryozoa from the Gerster Formation, northeastern Nevada. Contributions to Geology, University of Wyoming, 24:211217.

Girty, G.H. 1911. New genera and species of Carboniferous fossils from the Fayettville Shale of Arkansas. Annals of the New York Academy of Sciences, 20:189-238.

Gorjunova, R.V. 1970. New Early Permian bryozoans from the Southeast Darvaz and Pamir, p. 60-68. In Astrova, G.G. and Chudinova, I.I. (eds.), New Species of Palaeozoic Bryozoans and Corals. Nauka, Moscow. (In Russian)

Gorjunova, R.V. 1975. Permian bryozoans of the Pamir. Trudy Paleontologicheskogo Instituta Akademii Nauk SSSR, 148:1-125. (In Russian)

Gorjunova, R.V. 1985. Morphology, system und phylogeny of Bryozoa (Order Rhabdomesida). Trudy Paleontologicheskogo instituta Akademii Nauk SSSR, 208:1-152. (In Russian)

Gorjunova, R.V. 1992. Morphology and system of the Paleozoic Bryozoa. Trudy Paleontologicheskogo instituta Rossiiskoi Akademii Nauk, 251:1-168. (In Russian)

Gorjunova, R.V. 1994. On the taxonomic rank and phylogeny of timanodictyoid bryozoans. Paleontologicheskii Zhurnal, 1994(2):44-58. 
Gorjunova, R.V. 2002. Pseudorhabdomeson - a new genus of Carboniferous bryozoans: morphology and astogeny. Paleontological Journal, 36(3):490-501.

Gorjunova, R.V. and Weis, O.B. 2012. A new genus Acupipora gen. nov. from the Upper Carboniferous of the East European platform and problem of classification of bryozoans of the order Fenestellida. Paleontological Journal, 46(1):16-28.

Hageman, S.J., Bock, P.E., Bone, Y., and McGowran, B. 1998. Bryozoan growth habits: Classification and analysis. Journal of Paleontology, 72:418-436.

Hageman, S.J., Bone, Y., McGowran, B., and James, N.P. 1997. Bryozoan colonial growth form as paleoenvironmental indicators: evaluation of methodology. Palaios, 12:405-419.

Hageman, S. and McKinney, F.K. 2010. Discrimination of fenestrate bryozoan genera in morphospace. Palaeontologia Electronica, 13.2.7A:1-43 palaeo-electronica.org/2010_2/206/index.html

Hall, J. and Simpson, G.B. 1887. Corals and Bryozoa from the Lower Heldelberg, Upper Heldelberg and Hamilton Groups. Geological Survey of the State of New York, 6:98, 265-288.

Hodges, K.V. 2000. Tectonics of the Himalaya and southern Tibet from two perspectives. GSA Bulletin, 112(3):324-350.

Hosking, L.F.V. 1931. Fossils from the Wooramel district, Western Australia. Journal of the Royal Society of Western Australia, 17:7-52.

King, W. 1849. On some families and genera of corals. Annals and Magazine of the Natural History, 2:388390.

Li, X., Wang, C., Li, Y., Wei, Y., and Chen, X. 2014a. Definition and composition of the Zhongba Microterrane in southwest Tibet. Acta Geologica Sinica, (2014) 8:1372-1381. (In Chinese with English abstract)

Li, X., Wang, C., Li, Y., Wei, Y., and Chen, X. 2014b. The disaggregation of the Permian Quga Formation in Zhongba area, southwestern Tibet. Geological Bulletin of China, 33(5):1372-1381. (In Chinese with English abstract)

Linskaya, A.B. 1951. New species of Lower Permian Trepostomata from the Northern Urals. Byulleten' Moskovskogo Obshchestva Ispytatelei Prirody, Otdel Geologicheskii, 1:145-151. (In Russian)

Liu, X. 1976. Phylum Bryozoa, p. 131-155. In (editor unknown), Palaeontological Atlas of north China. Inner Mongolia, Vol. 1. Palaeozoic Volume. Geological Publishing House, Peking. (In Chinese)

Liu, X. and Wang, S. 1987. Late Carboniferous and Early Permian Bryozoa from Xainza, northern Xixang (Tibet). Professional paper on stratigraphy and paleontology, 18:1-31. (In Chinese with English abstract)

Lonsdale, W. 1844. Description of six species of corals from the Palaeozoic formation of Van Diemen's Land, p. 161-169. In Darwin, C. (ed.), Geological Observations on the Volcanic Islands Visited during the Voyage of H. M. S. "Beagle". Smith, Elder \& Co., London.
Ma, J.-Y., Buttler, C.J., and. Taylor, P.D. 2014. Cladistic analysis of the 'trepostome' Suborder Esthonioporina and the systematics of Palaeozoic bryozoans. Studi Trentini di Scienze Naturali, 94:153-161.

M'Coy, F. 1844. A Synopsis of the Characters of the Carboniferous Limestone Fossils of Ireland. Dublin University Press, Dublin.

M'Coy, F. 1849. On some new genera and species of Paleozoic corals and Foraminifera. Annals and Magazine of Natural History, 3:119-136.

McKinney, F.K. and Jackson J.B.C. 1989. Bryozoan Evolution. Unwin Hyman, Boston.

Metz, K. 1946. Permische Bryozoen aus Nordtibet, p. 172-191. In Norin, E. (ed.), Reports of the Scientific Expedition to the Northwetern Provinces of China under Leadership of Dr. Sven Hedin, The SinoSwedish Expedition Publication 29 III, Geology, 7. Borkforlags Aktiebolaget Thule, Stockholm. (In German)

Morozova, I.P. 1959. New genus of Family Fistuliporidae in the Devonian of Kuznetz Basin. Trudy Paleontologicheskogo Instituta Akademii Nauk SSSR, 2:7981. (In Russian)

Morozova, I.P. 1960. Family Eridotrypellidae, p. 65. In Orlov, Ju.A. (ed.), Osnovy Paleontologii. Bryozoa, Brachiopoda (Supplement: Phoronida). Akademia Nauk SSSR, Moscow.

Morozova, I.P. 1965. Bryozoa. Trudy Paleontologicheskogo Instituta, 108:183-197. (In Russian)

Morozova, I.P. 1966. A new suborder of the cryptostomid Bryozoa. Paleontologicheskii Zhurnal, 2:33-41. (In Russian)

Morozova, I.P. 1970. Late Permian Bryozoa. Trudy Paleontologicheskogo Instituta SSSR, 122:1-347. (In Russian)

Morozova, I.P. 1974. Revision of the bryozoan genus Fenestella. Paleontological Journal, 8(2):167-180.

Morozova, I.P. 1981. Late Paleozoic bryozoans from the northeastern USSR. Trudy Paleontologicheskogo Instituta Akademii Nauk SSSR, 188:1-119. (In Russian)

Morozova, I.P. 1991. Bryozoa, p. 23-26, 76-91. In (editor unknown), Permian Invertebrates of Southern Mongolia. Trudy Sovmestnoi Sovetsko-mongolskoi paleontologicheskoi expeditsii. Nauka, Moscow. (In Russian)

Morozova, I. P. 2001. Bryozoans of the Order Fenestellida (morphology, system, historical development). Trudy Paleontologischeskogo Instituta, 277:1-176. (In Russian)

Morozova, I.P. and Krutchinina, O.N. 1986. Permian Bryozoa of the Arctic Region. Nauka, Moscow. (In Russian)

Morozova, I.P. and Lisitsyn, D.V. 1996. Revision of the genus Polypora M'Coy, 1844. Paleontological Journal, 30:530-534.

Nakrem, H.A. 1994. Middle Carboniferous to Early Permian bryozoans from Spitsbergen. Acta Palaeontologica Polonica, 39:45-116. 
Nelson, C.S., Hyden, F.M., Keane, S.L., Leask, W.L., and Gordon, D.P. 1988. Application of bryozoan growth form studies in facies analysis of non-tropical carbonate deposits in New Zealand. Sedimentary Geology, 60:301-322.

Nikiforova, A.I. 1938. Types of Carboniferous Bryozoa of the European part of the USSR. Paleontologiya SSSR (Paleontology of the USSR) 4[5](1). Paleontologicheskii Institut Academii Nauk SSSR, Moscow. (In Russian)

Nikiforova, A.I. 1939. New species of the Upper Paleozoic bryozoans of the Bashkirian Urals. Trudy Neftyanogo geologo-razvedochnogo instituta, Series $A$, 115:70-102. (In Russian)

Pedley, H.M. 1976. A palaeoecological study of the Upper Corallin Limeston, Terebratula-Aphelesia bed (Miocene, Malta) based on bryozoan growth form studies and brachiopod distributions. Palaeogeography, Palaeoclimatology, Palaeoecology, 20:209-234.

Reid, C.M. 2003. Permian Bryozoa of Tasmania and New South Wales: systematics and their use in Tasmanian biostratigraphy. Memoirs of the Association of Australasian Palaeontologists, 28:1-133.

Reid, C.M. and James, N.P. 2008. Climatic response of Late Paleozoic bryozoans: diversity and composition of Gondwanan faunas, p. 243-250. In Hageman, S.J., Key, M.M.J., and Winston, J.E. (eds.), Bryozoan Studies 2007. Proceedings of the 14th International Bryozoology Association Conference, Boone, North Carolina, July 1-8, 2007, Virginia Museum of Natural History. Special Publication No. 15. Virginia Museum of Natural History, Martinsville, Virginia.

Reid, C.M. and James, N.P. 2010. Permian higher latitude bryozoan biogeography. Palaeogeography, Palaeoclimatology, Palaeoecology, 298:31-41.

Romantchuk, T.V. 1967. New bryozoans of the Order Trepostomata of the Upper Permian of the Khabarovsk Territory. Paleontologicheskii Zhurnal, 1967(2):69-73. (In Russian)

Romantchuk, T.V. and Kiseleva, A.W. 1968. New Late Permian bryozoans from the Far East. Paleontologicheskii Zhurnal, 1968(4):55-60. (In Russian)

Ross, J.R.P. 1995. Permian Bryozoa, p. 196-209. In Scholle, P.A. et al. (eds.), The Permian of Northern Pangea. Springer-Verlag, Berlin-Heidelberg.

Ross, J.R.P. and Ross, C.A. 1990. Late Paleozoic bryozoan biogeography. Geological Society Memoir, 12:353-362.

Sakagami, S. 1961. Japanese Permian Bryozoa. Palaeontological Society of Japan, Special Papers, 7:1-58.

Sakagami, S. 1963. Bryozoa from Pulau Jong, the Langkawi Islands, northwest Malaya. Japanese Journal of Geology and Geography, 34:205-209.

Sakagami, S. 1964. Bryozoa of Akiyoshi, Part 2. Lower Carboniferous Bryozoa from the Uzura Quarry. Transactions and Proceedings of the Palaeontological Society of Japan, 3:295-308.

Sakagami, S. 1966. The cryptostomatous bryozoan fauna from Ko Muk, peninsular Thailand.
Japanese Journal of Geology and Geography, 37:157-168.

Sakagami, S. 1968. Permian Bryozoa from Khao Phrik, near Rat Buri, Thailand. Contributions to the Geology and palaeontology of Southeast Asia. 43. Geology and palaeontology of Southeast Asia, 4:45-66.

Sakagami, S. 1970. Addition to the Permian Bryozoa from Ko Muk, peninsular Thailand.

Geology and Palaeontology of Southeast Asia, 8:4368.

Sakagami, S. 1973. Permian Bryozoa from Khao Raen, near Rat Buri, Thailand. Geology and Palaeontology of Southeast Asia, 12:75-89.

Sakagami, S. 1975. Permian Bryozoa from Khao Hin Kling, near Phetchabun, north-central Thailand. Geology and Palaeontology of Southeast Asia, 16:33-43.

Sakagami, S. 1976. Paleobiogeography of the Permian Bryozoa on the basis of the Thai-Malayan district. Contributions to the geology and palaeontology of Southeast Asia, 17. Geology and Palaeontology of Southeast Asia, 17:155-172.

Sakagami, S. 1999. Permian bryozoans from some localities in the Khao Hin Kling Area near Phetchbun, north-central Thailand. Bulletin of the Kitakyushi Museum of Natural History, 18:77-103.

Sakagami, S. and Pillevuit, A. 1997. Permian bryozoans from the exotic formations in Oman. Palaeontological Research, 1(3):200-224

Sakagami, S., Sciunnach, D., and Garzanti, E. 2006. Late Paleozoic and Triassic bryozoans from the Tethys Himalaya (N India, Nepal and S Tibet). Facies, 52(2):279-298.

Salter, J.W. 1865. Palaeozoic. Palaeontology of Niti in the Northern Himalya: Being Descriptions and Figures of the Palaeozoic and Secondary Fossils Collected by Colonel Richard Strachey, R.E. Military Orphan Press, Calcutta.

Schulga-Nesterenko, M.I. 1941. Lower Permian Bryozoa of Urals. Trudy Paleontologicheskogo Instituta Akademii Nauk SSSR. Paleontology of the USSR, 5:1276. (In Russian)

Schulga-Nesterenko, M.I. 1952. New Lower Permian bryozoans of Ural Mountains. Trudy Paleontologicheskogo Instituta, 37:1-79. (In Russian)

Shen, S. and Yugan, J. 1999. Brachiopods from the Permian-Triassic boundary beds at the Selong Xishan section, Xizang (Tibet), China. Journal of Asian Earth Sciences, 17:547-559.

Simpson, G.B. 1895. A discussion of the different genera of the Fenestellidae, p. 687-727. In (editor unknown), Thirteenth Annual Report of the State Geologist of New York for the Year 1894 (publisher unknown).

Simpson, G.B. 1897. A handbook of the genera of the North American Paleozoic Bryozoa, p. 405-669. Fourteenth Annual Report of the State Geologist of New York for the Year 1895 (publisher unknown). 
Smith, A.M. 1995. Palaeoenvironmental interpretation using bryozoans: a review. Geological Society of London Special Publication, 83:231-243.

Smith, A.M., Key, M.M., Jr., and Gordon, D.P. 2006. Skeletal mineralogy of bryozoans: Taxonomic and temporal patterns. Earth-Science Reviews, 78(34):287-306

Smith, A.M. and Nelson C.S. 1994. Selectivity in seafloor processes: taphonomy of bryozoans, p. 177180. In Hayward, P.J., Ryland, J.S., and Taylor, P.D. (eds.), Biology and Palaeobiology of Bryozoans. Olsen \& Olsen, Fredensborg.

Snyder, E.M. 1991. Revised taxonomic procedures and paleoecological implications for some North American Mississippian Fenestellidae and Polyporidae. Palaeontographica Americana, 57:1-275.

Stach, L.W. 1936. Correlation of zoarial form with habitat. Journal of Geology, 44:60-65.

Taylor, P.D. and Allison, P.A. 1998. Bryozoan carbonates through time and space. Geology, 26(5):459-462.

Termier, H. and Termier, G. 1971. Bryozoaires du Paleozoique superieur de Làfganistan. Documents des Laboratoires de Géologie de la Faculté des Sciences de Lyon, 47:1-52. (In French)

Toula, F. 1875. Permo-Carbon-Fossilien von der Westküste von Spitzbergen. Neues Jahrbuch für Mineralogie, Geologie und Paläontologie, 1875:225-264. (In German)

Trizna, V.B. 1939. New species of Upper Palaeozoic Fenestellidae and Acanthocladiidae from the Bashkirian Urals. Trudy Nauchno-issledovatel'skogo Geologo-razvedochnogo Instituta (NIGRI), 115:102144. (In Russian)

Trizna, V.B. 1950. On the characteristic of reefal and bedded facies of the Ufimian Plate. In "Mikrofauna neftyanych mestoroshdenyi SSSR" (Microfauna of the oilfields of the SSSR), Paper 3. Trudy VNIGRI, New Series, 31:47-144. (In Russian)

Trizna, V.B. and Klautzan, R.A. 1961. Bryozoans of the Artinskian of the Ufimian Plateau and their role in the stratigraphy of this stage in western Urals. Trudy Vsesojuznogo Nauchnoissledovatelskogo GeologoRazvedochnogo Instituta (VNIGRI), 179th edition, Microfauna of the USSR, 13:331-453. (In Russian)

Ulrich, E.O. 1882. American Palaeozoic Bryozoa. The Journal of the Cincinnati Society of Natural History, 5:233-257.

Ulrich, E.O. 1889. On some Polyzoa (Bryozoa) and Ostracoda from the Cambro-Silurian Rocks of Manitoba. Geological Natural History Survey Canada, Contributions to the micro-palaeontology of the Cambro-Silurian rocks of Canada, 2:22-57.

Ulrich, E.O. 1890. Palaeozoic Bryozoa: III. Geological Survey, 8:283-688.

Ulrich, E.O. 1896. Bryozoa, p. 257-291. In Eastman, C. (ed.), Zittel's Textbook of Palaeontology. Vol. 1. Macmillan, London.

Verna, V., Angiolini, L., Chaouachi, C., Soussi, M., Henderson, C., Davydov, V., Nicora, A., and Bougdar, M.
2010. Guadalupian brachiopods from Djebel Tebaga de Medenine, south Tunisia. Rivista Italiana di Paleontologia e Stratigrafia, 116(3):309-349.

Vine, G.R. 1884. Fourth report of the Committee appointed for the purpose of reporting on fossil Polyzoa, p. 161-209. In (editor unknown), Reports of the 53rd meeting of the British Association for Advances in Science. British Association for Advances in Science, London.

Vine, G.R. 1885. Further notes on new species and other Yorkshire Carboniferous fossil Polyzoa described by Prof. John Phillips. Proceedings of the Yorkshire Geological and Polytechnic Society, New Series, 8:377-393.

Waagen, W. and Pichl, J. 1885. Salt-range Fossils. Productus-Limestone Fossils. Memoire of the Geological Survey of India, Palaeontologica Indica, Series 13, (1):771-834.

Waagen, W. and Wentzel, J. 1886. Salt-range Fossils. Productus-Limestone Fossils: Coelenterata. Memoirs of the Geological Survey of India, Paleontologica Indica, Series 13 1:835-924.

Waterhose, J.B. 1966. Lower Carboniferous and Upper Permian brachiopods from Nepal. Jahrbuch der Geologischen Bundesanstalt Wien, 12:5-99.

Wyse Jackson, P.N. and Bancroft, A.J. 1995. Generic revision of the cryptostome bryozoan Rhabdomeson Young and Young, 1874, with description of two species from the Lower Carboniferous of the British Isles. Journal of Paleontology, 69(1):28-45.

Wyse Jackson, P.N., Reid, C.M., and McKinney, F.K. 2011. The status of Protoretepora de Koninck, 1878 (Fenestrata: Bryozoa), and description of $P$. crockfordae sp. nov. and $P$. wassi sp. nov. from the Permian of Australia. Alcheringa, 35(4):539-552.

Wyse Jackson, P.N., Reid, C.M., and McKinney, F.K. 2012. Fixation of the type species of the genus Protoretepora de Koninck, 1878 (Bryozoa, Fenestrata). Alcheringa, 36:137-138.

Xia, F. 1986. Carboniferous and Early Permian bryozoans from Xainza, northern Xizang. Bulletin of Nanjing Institute of Geology and Palaeontology, Academia Sinica, 10:201-254. (In Chinese with English abstract)

Xia, F. 1991. Early-Middle Permian bryozoans from Rutog region, Xizang (Tibet), p. 166-214. In Sun Dongli, Xu Juntao, et al. (eds.), Papers for Scientific Co-expedition of the Nanjing Institute of Geology and Regional Geological Survey Team, Geological Bureau of Xizang Stratigraphy and Palaeontology of Permian, Jurassic and Cretaceous of the Rutog Region, Xizang (Tibet). Nanjing University Press, Nanjing. (In Chinese and English)

Yanagida, J., a Research Group. 1988. Biostratigraphic study of Paleozoic and Mesozoic Groups in Central and Northern Thailand. An Interim Report. Department of Geology, Faculty of Sciences, Kyushu University, Fukuoka. 
Yang. J. 1956. Some cyclostomatous Bryozoa from the Permian rocks of western Hupeh. Acta Palaeontologica Sinica, 4:163-174.

Yang, J. and Lu, L. 1983. Upper Carboniferous and Lower Permian bryozoans from Kalpin of western Xinjiang. Palaeontologia Cathayana, 1:259-317.

Yang, J. and Lu, L. 1984. New material of Early Permian Bryozoa from southwest China Acta palaeontologica Sinica, 23:36-61. (In Chinese)

Yang, J., Lu, L., and Xia, F. 1981. Late Paleozoic bryozoans from Xizang, p. 81-100. In (editor unknown), The Series of the Scientific Expedition to the Plateau of Xizang. Palaeontology Book. Publisher and publication locality unknown. (In Chinese with English abstract)
Yang, J. and Xia, F. 1975. The bryozoan fossils from the Qomolangma Feng region, p. 39-70. In A Report of Scientific Expedition in the Mount Jolmo Lungma [Everest] Region. Palaeontology. Science Press, Peking. (In Chinese)

Young, J. 1883. On Ure's "Millepore". Tabulipora (Cellepora) Urii, Flem. Annals and Magazine of Natural History, 12(5):154-158.

Young, J. and Young, J. 1874. On a new genus of Carboniferous Polyzoa. Annals and Magazine of Natural History, Series 4, 13:335-339.

Zhang, S.X. 1976. Taxonomic names, in Late Paleozoic brachiopods from the Mount Jolmo Lungma region. $A$ Report of the Scientific Expedition in the Mount Jolmo Lungma Region (1966-1968), 2:159-271. 